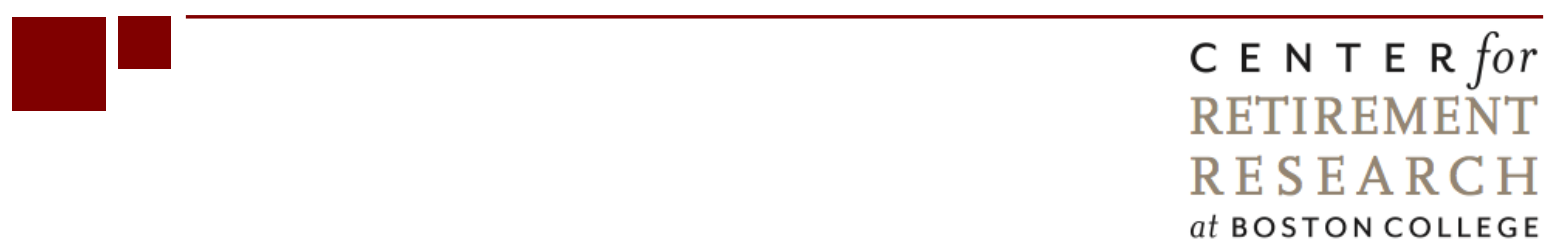

\title{
WHO IS INTERNATIONALLY DIVERSIFIED? EVIDENCE FROM 296 401(K) PLANS
}

Geert Bekaert, Kenton Hoyem, Wei-Yin Hu, and Enrichetta Ravina

CRR WP 2014-14

Submitted: July 2014

Released: November 2014

\author{
Center for Retirement Research at Boston College \\ Hovey House \\ 140 Commonwealth Ave \\ Chestnut Hill, MA 02467
}

Tel: 617-552-1762 Fax: 617-552-0191

http://crr.bc.edu

Geert Bekaert is the Leon G. Cooperman Professor of Finance and Economics at Columbia Business School. Kenton Hoyem is a research associate at Financial Engines, Inc. Wei-Yin Hu is vice president of financial research at Financial Engines, Inc. Enrichetta Ravina is an assistant professor of finance at Columbia Business School. The research reported herein was performed pursuant to a grant from the U.S. Social Security Administration (SSA) funded as part of the Retirement Research Consortium. The opinions and conclusions expressed are solely those of the authors and do not represent the opinions or policy of SSA, any agency of the federal government, Columbia Business School, Financial Engines, Inc., or Boston College. Neither the United States Government nor any agency thereof, nor any of their employees, makes any warranty, express or implied, or assumes any legal liability or responsibility for the accuracy, completeness, or usefulness of the contents of this report. Reference herein to any specific commercial product, process or service by trade name, trademark, manufacturer, or otherwise does not necessarily constitute or imply endorsement, recommendation or favoring by the United States Government or any agency thereof. The authors would like to thank Nicolas Crouzet, Katrina Evtimova, and, especially, Andrea Kiguel for excellent research assistance.

(C) 2014, Geert Bekaert, Kenton Hoyem, Wei-Yin Hu, and Enrichetta Ravina. All rights reserved. Short sections of text, not to exceed two paragraphs, may be quoted without explicit permission provided that full credit, including (C) notice, is given to the source. 


\title{
About the Steven H. Sandell Grant Program
}

This paper received funding from the Steven H. Sandell Grant Program for Junior Scholars in Retirement Research. Established in 1999, the Sandell program's purpose is to promote research on retirement issues by scholars in a wide variety of disciplines, including actuarial science, demography, economics, finance, gerontology, political science, psychology, public administration, public policy, sociology, social work, and statistics. The program is funded through a grant from the Social Security Administration (SSA). For more information on the Sandell program, please visit our website at: http://crr.bc.edu/about-us/grantprograms/stevenhsandell-grant-program-2/ send e-mail to crr@bc.edu, or call (617) 552-1762.

\section{About the Center for Retirement Research}

The Center for Retirement Research at Boston College, part of a consortium that includes parallel centers at the University of Michigan and the National Bureau of Economic Research, was established in 1998 through a grant from the Social Security Administration. The Center's mission is to produce first-class research and forge a strong link between the academic community and decision-makers in the public and private sectors around an issue of critical importance to the nation's future. To achieve this mission, the Center sponsors a wide variety of research projects, transmits new findings to a broad audience, trains new scholars, and broadens access to valuable data sources.

\author{
Center for Retirement Research at Boston College \\ Hovey House \\ 140 Commonwealth Avenue \\ Chestnut Hill, MA 02467 \\ phone: 617-552-1762 fax: 617-552-0191 \\ e-mail: crr@bc.edu \\ crr.bc.edu
}

\author{
Affiliated Institutions: \\ The Brookings Institution \\ Massachusetts Institute of Technology \\ Syracuse University \\ Urban Institute
}




\begin{abstract}
We examine the international equity allocations of over 3 million individuals in 296 401(k) plans over the 2006-2011 period. These allocations show enormous cross-individual variation, ranging between zero and over 75 percent, as well as an upward trend that is only partially accounted for by the slight decrease in importance of the U.S. market relative to the world market. International equity allocations also display strong cohort effects, with younger cohorts investing more internationally than older ones, but also each cohort investing more internationally over time. This finding suggests that the home bias phenomenon may slowly disappear over time. Worker's salary has a positive effect on international allocations, while account balance has a negative one, but these effects are not economically large. Education, financial literacy, and the fraction of foreign-born population measured at the zip code level have strong positive effects on international diversification, consistent with familiarity and information stories. In addition, states with more exports have higher international allocations.
\end{abstract}




\section{Introduction}

The proportion of domestic stocks in most investors' equity portfolios well exceeds their country's relative market capitalization in the world, making investors forego substantial diversification benefits. This home bias phenomenon remains one of international finance's major puzzles. An ever-growing number of studies investigate the determinants of home bias from both rational and behavioral perspectives (see Sercu and Vanpee, 2012, for a survey).

The country-level international under-diversification documented in the literature masks much individual heterogeneity. Table 1 shows statistics for the international equity allocation (as a percentage of the total equity allocation) of 3.8 million U.S. individuals in 296 different $401(\mathrm{k})$ accounts, over the $2006-2011$ period. We stratified the data into older people (born in 1960 or earlier) and younger people (born in 1980 or later), and contrast average international allocations for either the 5 most diversified firms relative to the 5 least diversified firms, or the most diversified state (Iowa) relative to the least diversified state (Nevada). Irrespective of the salary group (we considered three groups), people in Iowa have about 5 to $10 \%$ higher international allocations than people in Nevada; the difference for diversified versus non-diversified firms is larger still, at 20$30 \%$. Moreover, older people are consistently less internationally "diversified" than younger people.

Our analysis of this cross-individual dispersion provides a unique perspective relative to the related international finance literature, which has primarily used cross-country data on asset holdings to uncover various determinants behind home bias. Research has documented both host and destination (target) country factors behind these biases, but the focus has been mostly on destination country factors, such as corporate governance issues, stock market development and investment restrictions. ${ }^{1}$ To identify these destination country factors, studies then focus on the related problem of foreign investment bias, examining to what degree home biased countries under-invest in various countries. Particularly popular are explanations based on information barriers (Ahearne, Griever and Warnock, 2004; Brennan and Cao, 1997; Van Nieuwerburgh and Veldkamp, 2009) and familiarity biases (Portes and Rey, 2005).

\footnotetext{
${ }^{1}$ The determinants proposed by those studies include transaction costs (Glassman and Riddick, 2001), real exchange rate risks (Fidora, Fratzscher and Thimann, 2007), information barriers (Ahearne, Griever and Warnock, 2004), corporate governance issues (Dahlquist, Pinkowitz, Stulz and Williamson, 2003; Kho, Stulz and Warnock, 2009), stock market development (Chan, Covrig and Ng, 2005), the need to hedge local consumption streams (Aviat and Coerdacier, 2007), investment restrictions (Bekaert, Siegel, Wang, 2013) and lack of familiarity (Portes and Rey, 2005), to name a few.
} 
Bekaert, Siegel and Wang (2013) document the cross-country dispersion in home bias relative to a CAPM (relative market capitalization) benchmark for 35 countries, normalized to be between 0 (no home bias) and 1 (all equity holdings in domestic stocks). The least home-biased developed country is the Netherlands with a home bias over the 2001-2009 period of only 34.7\%; while Spain, the worst, has a home bias of $87.5 \%$. It is straightforward to convert the numbers of Table 1 into relative home bias numbers (we divide by the fraction of world market capitalization accounted for by non-US markets, which is $64.4 \%$, and subtract that ratio from 1 ). For a " 1960 " cohort person with median salary at a poorly diversified firm normalized home bias is $92.45 \%$; whereas it is only $43.63 \%$ for a " 1980 " cohort person at a relatively well diversified firm, indicating that the cross-individual dispersion of home bias within the US is of the same order of magnitude as the cross-country dispersion in home bias.

Understanding this cross-individual dispersion may have profound implications for the international diversification literature. First, pure destination country factors, such as various investment restrictions in different countries or corporate governance problems, which are difficult to measure to begin with, cannot explain the cross-individual variation in international diversification for US individuals. Second, the cross-individual dispersion suggest that individual heterogeneity in preferences or background risk may play a large role in driving international under diversification and may be more important than the "cost" of international investing or international risk factors such as transaction costs and real exchange rate risk. ${ }^{2}$ Personal characteristics such as age, salary and wealth may play a role. Familiarity bias (Huberman, 2001) or informational asymmetry between local and non-local investors (Coval and Moskowitz, 1999) also have implications for the incidence of "international" home bias for individuals in different locations within the US (e.g. based on the number of foreign born people in a region), or working for different firms (international versus domestic firms). Finally, cross-country studies miss a set of potentially very important determinants of home bias, which may be policy relevant, such as education levels or the quality of the $401(\mathrm{k})$ investment options available to the individual.

Each individual in our sample can be characterized by personal characteristics, the area where she lives, captured by the zip code, and the firm she works for. We therefore proceed in three steps. We first analyze the importance of personal characteristics like age, cohort, salary, and wealth indicators. From these regressions, we identify zip code

\footnotetext{
${ }^{2}$ We implicitly assume here that there is at least one international fund in the $401(\mathrm{k})$ plan. There may of course be variation in the quality and diversity of the foreign investment options in different $401(\mathrm{k})$ plans and we will control for this in the final version of the article.
} 
and firm (plan) fixed effects, and analyze these separately. Fortunately, several of the firms in our sample are large firms with multiple branches in different locations; in some cases spread out over the whole country. This enables us to meaningfully differentiate location from firm effects.

One key fact emerging from the data is that there is an upward trend in the extent of international diversification. We show that part of this, but only a small part, is the potentially rational response to the slowly decreasing importance of the US market in the world equity markets. We also find negative age and positive cohort effects. As is wellknown (see Ameriks and Zeldes, 2004), time, age and cohort effects cannot be separately identified. We argue that the most plausible characterization of the data is a strongly positive cohort effect coupled with a pure time effect. The cohort effect is partially responsible for the trend towards more international diversification over time. In addition, each cohort invests more internationally each year, which delivers the strong upward trend in international diversification. The trend and cohort effects are consistent with the ongoing globalization process making people more comfortable with foreign investments over time.

In studying the zip code effects, we find evidence potentially consistent with the familiarity hypothesis. Zip codes with a higher percent of the population born in foreign countries have substantially higher international allocations. The regressions control for a large number of other zip code specific characteristics, including the average (median) house value per zip code, and state income and growth levels. Also consistent with the familiarity or information hypotheses, is our finding that more export-oriented states feature higher international allocations. Importantly, we find that higher education levels lead to a significantly higher international equity allocation, both statistically and economically. The same is true for a survey measure of financial literacy. These effects are orthogonal to the immigration effect.

The firm fixed effects reveal that employees of profitable firms invest less and employees in private firms, most of which are foreign-controlled, invest more in international equity.

Hitherto, the large majority of the home bias studies are based on aggregate statistics, whereas an individualized perspective on home bias is largely limited to the studies on Swedish households by Calvet et al. (2007), Karlsson and Norden (2007) and Norden (2010). Calvet et al. (2007) do not specifically focus on international diversification, but the article mentions that Swedish households are relatively well diversified internationally because popular Swedish mutual funds have a high international 
allocation. Karlsson and Norden use a sample of 9,415 Swedish individuals for the year 2000 to study the likelihood of home bias, finding that wealth affects it negatively and age positively. Norden (2010) shows that under-diversified people are worse off than people who are well diversified internationally, but the advantage of the latter is diminished by their proclivity to excessively churn their portfolio. Graham, Harvey, and Huang (2009) use a UBS survey on 1,000 investors, to demonstrate that investors who feel competent trade more often and have more internationally diversified portfolios.

The remainder of the article is organized as follows. Section I describes the data and some summary statistics. Section II investigates the effect of personal characteristics and time effects on international diversification, whereas Section III focuses on geography, and section IV on firm effects. Section V reports a number of robustness checks, aimed primarily at showing that the account variation we rely on mostly reflects portfolio variation at the individual level. The final section offers some concluding remarks and outlines further analysis to be conducted.

\section{Individualizing International Diversification}

\section{Data description}

To implement this study we use a large proprietary dataset made available by Financial Engines, the market leader in online financial advice for 401(k) plans in the U.S., which includes record-keeper information on demographic characteristics, balances, salary, 401(k) contributions, household zip codes and the "style" of the asset allocation (see Sharpe, 1992) split up over 6 asset classes and company stock. The underlying style analysis applied to the funds in each plan uses 15 asset classes. Style analysis finds asset class weights such that the residual return (the difference between the actual fund return and the style return) has minimal variance, with the weights adding up to 1 and constrained to be non-negative. Priors based on each fund's investment objectives and the use of all available data with exponentially declining weights help reduce estimation noise. One of the aggregated asset classes is "International Stocks" and its underlying style analysis model uses indices on European, Pacific and Emerging stock markets.

We have data on 3.8 million individuals. Data are drawn every quarter, with any given individual being sampled every 6 months. For a limited number of companies, the data sample starts in 2005 , but the sample becomes much more complete during the second 
half of 2006 and runs till the end of 2011. In addition, we collect detailed information from 5500 IRS forms on the investment options, and other features of the 401(k) plans, such as employer contributions and vesting schedules. This information is publicly available in a non-standardized format and was extracted using the high quality assistance of a large pool of research assistants and an Indian outsourcing firm. The final data set combines proprietary data from Financial Engines, public information on 401(k) plans, financial information on the companies, and Census and other sources of socio-economic data matched through household zip codes. While Financial Engines provides financial advice and asset management services, for the purposes of this study we excluded from the sample all the accounts receiving financial advice or being managed by Financial Engines and we focused on those accounts that were managed by the individual. Our data include separate information on the allocation to target date funds and we control for it in our analysis.

Our sample contains 296 firms. In Appendix Tables 1 and 2 we report some characteristics of the firms and workers in our sample and compare them to the firms in Compustat and the S\&P500 Index, and to the population of full-time U.S. workers as reported in the Current Population Survey (CPS). In terms of size, whether we look at assets, sales or numbers of employees, the firms in our sample are substantially larger than the Compustat firms. Average net income and capital expenditures in our firms also exceed that of Compustat firms. For example, the median number of employees is about 4500 in our sample, whether it is only 950 in the Compustat sample, while the average number of employees per firm is more than 17,000 in our sample and about 7,600 in Compustat. The presence of such large companies means that the employees of one firm may be geographically dispersed across the country. Our firms have higher ROA's but their leverage ratios are similar to those of the companies in Compustat. Average annual returns are higher in our sample but they are very dispersed because of the crisis occurring in the middle of our sample period. Compared to the firms in the S\&P500, the firms in our sample are smaller, with slightly smaller asset size but far fewer employees. Our companies are mostly established companies, with the median age being 65 years and the 90\% range varying between 9 and 148 years. Finally, in Panel D we contrast the characteristics of the private and public firms in our sample. The public firms in our sample are larger in terms of assets, sales and number of employees. However, the private firms are not small upstart companies. Their median age is 62 years and the median number of employees is about 2500 . The average plan size is large, roughly USD 
1 billion on average, but there are lots of small plans as well, so that the median size is only about USD 300 million.

In Appendix Table 2, we compare worker characteristics in our sample with those of full time workers in the overall population. The workers in our sample tend to have higher salaries with the average and median salaries being around 15 to $20,000 \$$ higher than in the population at large. The average tenure is also about 5 years longer. Finally, the workers in our sample are on average about 4 years older. Salary shows a smooth concave pattern with respect to age, first almost linearly increasing, then flattening out around the 51-55 age group, with salaries starting to decrease for people aged over 60 . We also report account values for our sample, which have a very skewed distribution with the mean at $\$ 70,000$ higher than the average annual salary, but the median value of $\$ 25,786$ actually lower than the median annual salary. Account values may reflect a mixture of tenure, past salaries and contribution rates. Contribution rates also vary between 0 and $17 \%$, and are on average equal to $6 \%$.

\section{Measuring International Diversification}

We start with some simple notation. Let wint $\mathrm{t}_{\mathrm{t}, \mathrm{i}}$ be the allocation to international equities of individual $i$ at time $t$ and $w \mathrm{q}_{t, \mathrm{i}}$ her allocation to all equities (domestic and foreign equities). Our main variable of interest is the extent of international equity diversification, $\operatorname{idiv}_{\mathrm{t}, \mathrm{i}}=$ wint $_{\mathrm{t}, \mathrm{i}} / \mathrm{weq}_{\mathrm{t}, \mathrm{i}}$. The international home bias literature has used a wide range of measures, including international holdings over GDP (Aviat and Coeurdacier, 2007), or portfolio flows scaled by market capitalizations (Portes and Rey, 2005), but our focus is on portfolio choice, so that the international equity allocation is the natural variable to focus on. A number of articles (Ahearne et al, 2004, for example) have used relative weights, controlling for what the allocation would have to be under, typically, a simple World CAPM benchmark. Such relative weights also partially control for international versus local valuation changes. We will use such a CAPM benchmark weight in our empirical analysis but focus on the actual extent of international equity diversification as our main variable of interest. Bekaert, Siegel and Wang (2013) study several biases plaguing standard measures, including size biases arising from the fact that countries with a relatively large market capitalization are mechanically less likely to be severely home biased on a relative basis than are countries with a small market capitalization. ${ }^{3}$ However,

\footnotetext{
${ }^{3}$ Measures such as the natural logarithm of the relative weight as used in the often-cited article by Chan, Covrig and $\mathrm{Ng}$ (2005), for example, show substantial size biases. 
because we focus on allocations from citizens of one country, we need not to worry about such biases.

We would like to also characterize the international allocation to bonds, but we do not have the data, as the bond asset allocation reported in our data set does not distinguish domestic from international bonds (even though the original style analysis performed by FE did have an international bond category). This also makes it natural not to scale by the total holdings but only by equity holdings.

The focus on equity diversification has two additional advantages. First, by focusing on international allocation among stock market participants, we avoid confusing international non-diversification with stock market non-participation. Second, the focus on equity allocation potentially circumvents issues raised by optimal asset location. A high bond allocation and low equity allocation may reflect optimal asset location, given that the effective tax rate on bonds is mostly higher than on equities. Yet, under certain assumptions, the relative equity allocation should be constant across different accounts, even across taxable and tax deferred accounts (Huang, 2008), and therefore the idiv variable can be meaningfully examined even in accounts with relatively low equity allocations.

\section{International Diversification across the US}

\section{Insert Figure 1 here: Cross-individual variation in International Diversification}

In Panel A of Figure 1 we show a histogram of the international allocations over all of our observations. The average allocation is $17.8 \%$, and $37 \%$ of our observations lie between 10 and $25 \%$. In addition, $17 \%$ of the allocations are exact zeroes, while $3 \%$ of our observations reflect allocations to international equity of over $50 \%$.

The reason the average allocation of $17.8 \%$ is usually viewed as "under"-diversification, is that foreign equity markets during our sample period represent on average $64 \%$ of world market capitalization (computed using MSCI data; the MSCI index covers approximately $85 \%$ of the free float-adjusted market capitalization in each country). We denote the relative importance of foreign equity markets in world markets as idiv $_{t, b m}$. Note that this benchmark is only optimal under the strict assumptions of the CAPM, but we use it here as a reference point for our analysis. 
In panel $\mathrm{B}$ of Figure 1, we show the histogram for relidiv $v_{t, \mathrm{i}}=\operatorname{idiv}_{\mathrm{t}, \mathrm{i}} / \operatorname{idiv}_{\mathrm{t}, \mathrm{bm}}$. When relidiv is larger than 1 , the individual is over-diversified; if it is 1 , the individual invests according to existing relative market capitalizations, while 0 represents full home bias. The statistic is bounded from above by 100 divided by the fraction of the world market capitalization represented by foreign equity markets. This bound is $156 \%$, when evaluated with the average value of the foreign equity market fraction. Looking at Figure 1 (Panel B), we see that only slightly over $2 \%$ of the observations are higher than $90 \%$, representing almost full or over-international diversification. Slightly over $47 \%$ of the observations show relative diversification less than $25 \%$.

\section{Insert Figure 2: Location and International Diversification}

Figure 2 shows the international diversification averages for each state. Aggregating at the state level compresses the distribution considerably, but we still clearly see a spread between relatively well-diversified states (Utah, Iowa, Hawaii) with idiv's of over 20\%, and poorly diversified states (Alabama, West Virginia, and Nebraska) with idiv's close to $15 \%$.

\section{Insert Figure 3: Firms and International Diversification}

In Figure 3, we show the histogram after aggregating idiv and relidiv over firms. One possibility is that the quality and diversity of a firm's 401(k) plan options is the main driver of the observed cross-individual variation in international allocations. For example, Elton, Gruber and Blake (2004) study over 400 plans and find them "inadequate" in $62 \%$ of the cases. More generally, if the inter-personal characteristics are not well diversified within a firm, or firm features play a big role in home bias (either through location effects, firm culture, industry, or plan features), then the distribution of international allocations should remain relatively wide, compared to Figure 1. Alternatively, if pure inter-personal characteristics are an important source of cross-individual variation in international allocations, aggregating over individuals in a firm is likely to eliminate much of the cross-sectional variation we observe in Figure 1. Figure 3 reveals that $84.5 \%$ $(69.90 \%)$ of average firm (relative) international allocations are in the $10-25 \%$ (25-50\%) range, a much tighter distribution than in Figure 1. This suggests that personal characteristics may explain much of the observed inter-personal variation in international allocations.

Finally, Figure 4 focuses on potential time effects in international diversification by graphing quarterly time fixed effects. In Panel A, we simply show time fixed effects in idiv, and they exhibit a marked upward trend, roughly increasing from about $12 \%$ to $22 \%$ 
in 2010, before dropping back to $18 \%$ in 2011, when European stock markets experienced a downturn following the flare-up of the sovereign debt crisis in August of that year. In Panel B, we graph the same time fixed effects, but super-impose the proportion of world markets accounted for by non-US markets. Clearly, this proportion increased over time as well, moving from about 60 to $65 \%$ over the sample period. Thus, when investigating international allocations from the perspective of a simple World CAPM benchmark, international allocations should have increased over time. Alternatively, inertia coupled with different valuation changes for foreign versus domestic markets may also cause individuals to become automatically more diversified over time. In Panel $\mathrm{C}$, we show the time effects in relidiv, which controls for the variation in the international equity market capitalization proportion. The figure shows that there is a trend in international allocations over and above what happens to the underlying market capitalization benchmark. Nevertheless, we always include the benchmark foreign equity proportion as an independent variable in our regressions, and we will also verify whether relative returns in foreign versus domestic equity have a large effect on international allocations.

Insert Figure 4: Trends in International Diversification

\section{Personal Characteristics and International Diversification}

\section{II.1 On Trends, Age Effects and Cohorts.}

\section{Trends}

In Figure 4, we noted a marked increase in international diversification over time. We therefore first focus on this time effect. A positive time trend can be due to a pure positive time effect, a positive cohort effect with older cohorts investing less in international stocks, or a negative age effect coupled with a change in the age distribution, or some combination of the above. As is well known (see the seminal paper by Ameriks and Zeldes (2004)), these three effects, when modeled as is usual by dummy variables, are co-linear and cannot be separately identified. Yet, if the effects are persistent, identifying them is important for predicting future trends in international diversification. In this section, we explore the time effects in international diversification.

Table 2 reports some summary statistics on the personal characteristics that we will refer to throughout this section. Our actual regression results are reported in Table 3. For each 
specification, we run three different panel OLS regressions, one with the listed independent variables, one controlling for firm fixed effects, and one controlling for zip code fixed effects (there are close to 30,000 different zip codes represented in our sample). For each regression coefficient, we report OLS t-statistics in squared brackets, and indicate statistical significance at the 1,5 and 10\% levels, using the usual 3,2 and one asterisk(s). While the fixed effects should be expected to control for natural sources of correlation in the OLS residuals, we also run regressions using standard errors clustered at the firm level, to not only account for firm fixed effects but also changes in plan features at the firm level that may have happened during our sample period. For example, a number of firms introduced automatic enrollment plans that may have also affected the investment choices of individuals (see Madrian and Shea, 2001). These clustered standard errors are extremely conservative and produce standard errors about 40 times larger than the standard errors in alternative specifications with firm or zip code fixed effects. To examine the sources of these increased standard errors, we also considered specifications with clustering at the personal level or at the firm-"wave" level and regressions with firm-year or firm-"wave" fixed effects. We define waves in terms of tenure of people at the firm, surmising that people starting in a firm in the same year (or close to one another) may receive similar information regarding investment options, face similar investment options and return environments, and may even have personal contacts through investment information sessions that may influence their investment decisions (Duflo et al., 2006). The firm clustered standard errors deliver the largest standard errors among all these specifications. The main sources of these increased errors are the correlation of an individual's allocation over time (see Kezdi, 2004, for a discussion of the potential importance of such correlation), and the correlation between individuals joining the firm at a similar time ("tenure waves."). We indicate significance with clustered standard errors at the $1 \%$ level with an underscore and a bold; and significance at the 5 or $10 \%$ levels with an underscore only.

One plan feature that is important enough to warrant being controlled for in all of our regressions is the presence of target date funds. Because target date funds control the international asset allocation within their portfolios, we include a variable representing the percent of a person's account balance that is invested in target date funds. As Table 2 shows, the average target date allocation is $16 \%$, with a number of plans not featuring target date funds at all, and some individuals investing their full balance in target date funds. In addition, we control for the fraction of international assets relative to the world market capitalization, the idiv benchmark, a possible source of a trend in international diversification discussed in the previous section. We compute this fraction specifically 
for each person, based on the time at which the information on the allocations was drawn, and use it as an independent variable in all specifications.

Our first regression in Table 3 simply adds a linear and quadratic trend to these two variables. All four independent variables are highly statistically significant with the coefficients as expected. That is, to capture the trend in the data, we need a trend over and above the trend in the capitalization benchmark. Nevertheless, the trend terms do not remain statistically significant when clustered standard errors are used.

We have also estimated a regression with time dummies. While these time dummies are significant using OLS standard errors, many become insignificant when clustered standard errors are used and in some specifications it is even impossible to compute standard errors. Moreover, the fitted temporal function generated by the specification with just a quadratic trend and the capitalization benchmark is almost indistinguishable from the temporal function generated by time dummies. We therefore prefer to use the parsimonious but economically equivalent quadratic trend specification.

There are a number of possible economic explanations for the trend result. First, we examine the role of cohort and/or age effects in temporal patterns in international equity allocations. Second, we examine the return experience effect described in Malmendier and Nagel (2011), and simple valuation effects (foreign versus US returns) coupled with inertia.

Age and Cohort Effects

Age and cohort results are reported in Table 3, Panels A and B. The cohort variable starts at 40 (for people born in 1940 or earlier) and ends at 90 (for people born in 1990 or later). Age is simply measured in years. We also run the more usual regressions with cohort dummies. However, unless rather coarse cohort dummies (spanning a decade) are used, statistical significance is compromised by using a large number of cohort dummies. Moreover, both age and cohort effects are well captured by a mildly quadratic function, the parametric functions have the advantage of being parsimonious, and the nonlinearities may even help identifying whether age, cohort or time effects fit the data best. Finally, the adjusted $\mathrm{R}^{2}$ from specifications with a parametric function is as high as those of specifications with dummies. Given that the age and cohort variables are $99 \%$ negatively correlated, putting them in one regression makes little sense. Instead Table 3 
reports regression results where either the cohort or age variable are added to our base "trend" regression, ether in linear form (Panel A) or quadratic form (Panel B). ${ }^{4}$

The table reveals that the cohort or age effects do not eliminate the trend, but the trend coefficients do not survive clustering whereas the age and cohort effects are always highly statistically significant. We find a positive cohort and a negative age effect. We postulate that the age effect is implausible on economic and statistical grounds. First, the age effect cannot really contribute to a general trend in international diversification, unless the age distribution has shifted over time towards younger people. We examine the age distribution over time in our sample and find it to be quite stable (results are available upon request). Not surprisingly, the trend coefficients become stronger in the age specification. Second, the age effect implies that investors decrease their international allocations as they age and that this decrease is counteracted by an overall trend towards more diversification. This seems illogical and unlikely. Moreover, if the global trend does not persist, the graying of the population would imply that home bias, over the long-run, would get worse in the aggregate. To test this directly but informally, we ran a regression of the change in idiv for each individual with multiple observations over the full sample onto a constant, the change in the benchmark idiv and the change in the target date fund allocation. A negative age effect would tend to make the constant negative in such a regression. We obtain a highly significant positive coefficient. Of course, this may simply reflect the overall positive trend, but despite substantial crossheterogeneity in international diversification, only $26 \%$ of the population decreases its international diversification over time. Finally, the quadratic specifications continue to yield an overall negatively sloped age function, but we never see both coefficients reach significance under clustered standard errors, with the coefficients varying quite a bit across specifications.

A cohort effect is much more plausible, both economically and statistically. We find a cohort coefficient of $0.16-0.17$, with rather limited evidence for a quadratic specification. Linear and quadratic functions are almost indistinguishable for most cohorts, with the exception of the very youngest cohorts where the presence of a quadratic term would somewhat mitigate the increase in international diversification. Because the quadratic coefficient is also not significant under clustered standard errors, we proceed with the linear specification. There are a couple of possible economic explanations for a cohort effect. The simplest one is the ongoing globalization process that is familiarizing particularly the younger generation with global markets and global investments. If this is

\footnotetext{
${ }^{4}$ We also ran a specification with firm-time fixed effects, where the latter where either at the annual or quarterly level. The key results regarding age and cohorts are robust in this specification.
} 
true, our results are potentially consistent with one of the most common findings in the international literature regarding the effect of familiarity on home bias. We come back to this hypothesis when we investigate zip code effects. The potential long-run implications are important, as a sticky cohort effect would suggest that home bias will go away gradually. However, the results imply that an individual will increase its international allocation by about $1.6 \%$ over a decade, making the aggregate trend implications of the cohort effect rather modest. While the cohort variable explains about $10 \%$ of the total variation explained by all independent variables, the average cohort varies too little within our sample period to cause a marked increase in international allocations. The average cohort was (19)62 in 2006 and (19)65 in 2011, implying only a $0.5 \%$ aggregate increase in idiv over that time period.

Figure 5 shows the international allocations by (coarse) cohorts, with people born before 1950, people born in the fifties, sixties, seventies, and after 1980. There is a monotonic relation from old (low idiv) to young (high idiv), but all cohorts also increase their international allocation over time. What drives this overall diversification trend is unclear. It may be due to the overall globalization phenomenon making people more comfortable with international investing. The ongoing globalization process may also affect international allocations by making the international opportunity set better over time thereby enticing more international investment. ${ }^{5}$

\section{Insert Figure 5 Cohorts and International Diversification}

\section{Return-Sensitive Variables}

Another potential reason for cohorts to matter is that investment behavior is shaped by past return experiences. Malmendier and Nagel (2011) show that recent stock market experiences shape the risk taking and asset allocation of US individuals. To examine this, they create a weight function of past returns, depending on a parameter, $\lambda$, which can imply quite general weight patterns of past returns until birth. They find $\lambda$ to be around 1.5, which means recent returns are weighted more heavily than returns in the more distant past. Using SCF data, regressions that include, inter alia, age and time dummies, suggest that this experience variable has a positive effect on stock market participation, risk tolerance and the proportion of risky assets held.

For our purposes, the relevant return is not the US stock market return, but the difference between the foreign return and the US return. People having experienced first - hand

\footnotetext{
${ }^{5}$ Corporate pension funds have also increased their international allocations over time. In the next iteration of the paper, we will compare the evolution of corporate international allocations with those of individuals.
} 
poor international returns relative to the experience in the US stock market (for example, the roaring '90s) may be more reluctant to invest abroad and vice versa. We use the return on the MSCI international index (excluding the US) minus the US return, measured in dollars. The "MN experienced return" then becomes in essence a complex interaction of age and time effects, and past relative returns. We estimate $\lambda$ together with the coefficient on the MN variable using non-linear least squares. Preliminary analysis suggests that the optimal $\lambda$ is likely to be relatively high. Trying various starting values, we find $\lambda$ to be 4.241 (see Table 4). This is substantially higher than the estimate in Malmendier and Nagel (2011), which was around 1.5, but still implies declining weights for relative returns. Because we only have international data since 1969 and there were virtually no international investments before 1980, a declining weight functions seem the only plausible economic outcome. We find that the $\mathrm{MN}$ effect is statistically significant and it even remains so when clustered standard errors are used. However, the coefficient is negative, not positive, which is not consistent with the experience effect documented in Malmendier and Nagel. To help interpret this finding, Figure 6 (Panel A) graphs the Malmendier -Nagel experienced return variable as a function of age for different points of time. Interestingly, the functions are mostly positive and decreasing with age; that is, younger people experienced more positive relative foreign returns, which may help explain the cohort effect we documented above. However, this effect is non-linear and depending on the year, from age 40 to 50 the effect becomes quite small (and even negative for the 2006 year, perhaps reflecting the experience of the nineties where the US market performed very well). The linear cohort effect dominates this experienced return effect however. For lower $\lambda$ 's, we do find sometimes positive coefficients, but this coefficient is then mostly not statistically significant. Note that the cohort effect remains statistically significant in all the regressions we run with the MN experienced return variable included, with the coefficient not varying much across specifications. Of course, as may be evident from our previous discussion of the nature of the $\mathrm{MN}$ variable, it should not be surprising that the $\mathrm{MN}$ variable and the cohort variable are $75 \%$ correlated. Because of this high correlation, we also run a specification with the $\mathrm{MN}$ variable but excluding the cohort variable. In this specification, $\lambda$ is estimated to be lower at slightly over 1.0, but the MN variable still features a negative coefficient (results are available on request). We graph the $\mathrm{MN}$ experienced returns as a function of age for this case in Panel $\mathrm{B}$ of Figure 6. Here, the function is negative over a small but important age range in the lower middle of the distribution, which contains a large fraction of youngish to middle aged people, which we know tend to invest more heavily in foreign stocks than the older generations. The very young receive a very high positive experienced foreign return, but are not likely very influential in the sample, whereas the very old are known to not invest 
in foreign equities. It is unlikely that the $\mathrm{MN}$ variable here really reflects return experiences that are influencing international allocations. Regressions which replace cohort by age effects yield results similar to those reported in Table 4. Given our results, the pure cohort variable appears an easier to interpret and more robust determinant of variation in international allocations, than the special cohort variable stressed by Malmendier and Nagel (2011).

We also examined an alternative specification of the MN variable, simply using the foreign return, rather than the foreign return minus the US return. Perhaps people narrowly focus on absolute performance. In fact, the idea of investors "chasing returns" in international markets is a standard one in the capital flow literature, going back to at least Bohn and Tesar (1996). When we run the non-linear least squares model with this variant, we find that $\lambda$ is now again around 1.00 , and the MN variable has a positive and statistically significant on international allocations (see Table 4). That is, people having experienced higher foreign returns allocate more internationally. The cohort effect remains robust. However, the coefficient is no longer significant with clustered standard errors. Note that when we drop the cohort variable, $\lambda$ does not change much in value, but the effect of the "return chasing" variable becomes statistically significantly negative, again casting doubt on the interpretation of the result (not reported).

A much simpler potential explanation of time variation in international diversification is that people exhibit inertia: they select an international allocation, perhaps when joining the firm, and never or rarely change it. If that is the case, the time variation in idiv should be partly explained by relative cumulative returns (foreign versus US) between the different records of account balances. ${ }^{6} \mathrm{We}$ compute these individualized cumulative returns using daily MSCI returns. In Table 4, we therefore also add these relative returns directly as an explanatory variable. It turns out that this variable also has the wrong negative sign and is not statistically significant under clustered standard errors. The introduction of firm or zip code fixed effects does not change these conclusions. Note that the regression still includes the benchmark idiv variable, which remains highly statistically significant and also partially reflects valuation changes. We therefore also consider a specification that excludes this variable. If we do so the sign of the coefficient on the relative return duly becomes positive, but it is not significant under clustered standard errors.

\footnotetext{
${ }^{6}$ It would be interesting to explicitly study active re-allocations. Such re-allocations are not trivial to identify, but we have ongoing work that tries to do exactly that.
} 
Finally, there is potentially a different explanation for the results with the MN variable. Looking back at Figure 6, for the years 2008 and 2010, for $\lambda$ equal to 1.1, the $\mathrm{MN}$ variable is positive for virtually all ages, and for $\lambda$ equal to 4.2 , these years feature the highest relative experienced returns. However, 2008 was also the year of one of the worst stock market performances ever, and 2010 was a turbulent year as well, marred by the flash crash and the European debt crisis flaring up again. It is often suggested that in times of stock market crashes, investors become more risk averse and become at the same time more home - biased. Perhaps the negative MN coefficient picked up this "Flight to Safety" effect? To measure this effect more directly, we rely on a Flights-to-Safety indicator proposed in Baele, Bekaert, Inghelbrecht and Wei (2012), who use data on bond and stock returns to measure the occurrence of stress periods in which stock markets decline and liquid benchmark bonds increase in value. We include the monthly incidence of Flights to Safety days they identify for the US as an explanatory variable in the regression. While the coefficient on the variable is indeed negative and highly statistically significant in the simple OLS regression and the zip code fixed effect regression, it switches sign for the firm fixed effect regression and is not significant with clustered errors.

Given the non-robust and/or insignificant results we find, we do not use any of the return sensitive variables in the benchmark specification that we take forward.

\section{II.2. The Effects of Income and Wealth}

We now address whether income and wealth have an effect on international diversification. We have data on salary and account balances. We also have data on tenure at the firm, but these data are less complete, and we decided not to use them because of their correlation with cohorts on the one hand and the fact that account values may also largely reflect a combination of tenure and salary on the other hand. We also collected the median house value at the zip code level from Zillow, which is, for many households, perhaps the best indicator of overall wealth. We express all these variables in 2005 dollars using the CPI to deflate. Note that Zillow only covers a subset of the zip codes represented by worker population, so that the sample size is about half the size of the one used in Table 4.

As Table 2 shows, the distributions of salary, account values and house values are all right skewed and we therefore take natural logarithms before using them as independent

variables. We consider both linear and quadratic specifications. The quadric term for 
house value is not statistically significant, but the quadratic terms for salary and account balances are and they are therefore kept in our final specification reported in Table 5. We report again the usual three specifications, but when zip code fixed effects are used, we must drop the house value as an independent variable because the cross-sectional variation dominates time-series variation in house values in the sample. Note that most of our benchmark variables ( $\%$ in target date fund, international diversification benchmark, trends, and cohort) maintain their sign and significance with the exception of the trend variables which become less positive than before.

The coefficients on salary, account balances and house values are mostly statistically significant, even under clustered standard errors. The effect of house value on international diversification is positive. To get a sense of the economic magnitude, an increase in house value of $\$ 50,000$ at the $\$ 200,000$ average house value, would generate roughly a $0.15 \%$ increase in idiv (the derivative with respect to house values for these magnitudes is the coefficient divided by 4 ). Because of the opposite signs on the linear and quadratic coefficients for both salary and account balances, they require a bit more discussion. Despite the negative linear effect, international allocations are a robustly positive function of salary. At the $\$ 45,000$ average salary, an increase of $\$ 10,000$ in salary would roughly generate a $0.33 \%$ increase in the international allocation coefficient (we compute the derivative of the quadratic function at $\$ 45,000$ and multiply by $\$ 10,000)$. For account balances, the estimated function is negative, but the effect is smaller. For an account balance of $\$ 20,000$, which is close to the mean and median of the data, a $\$ 5000$ increase would generate only a $0.05 \%$ drop in international diversification. Note that account balances and salary are positively correlated, so that their joint effect may be somewhat smaller than the univariate effects.

Because we lose so many observations with the Zillow database, we consider an alternative data source for house values, namely the Census-Bureau/American Community Survey. This survey provides the median house value per zip code over the 2008-2012 period. Hence, there is no panel available as with the Zillow database. Moreover, median house values over USD 1 million are reported as $+1,000,000$. Since this only affects 158 zip codes we set them simply to $1,000,000$. Our results, reported in columns (4) and (5) of Table 5, are very robust to using this variable instead of the Zillow database house value. The coefficients on account values and salaries are very close to those reported in the previous columns and the coefficient on house value now becomes somewhat higher at 0.82 with firm fixed effects, and 0.96 without, while retaining statistical significance. 
While the effects are not economically large, we do detect important salary and wealth effects, and will continue to use this specification as a benchmark specification in further analysis.

A major potential source of heterogeneity in asset allocations is variation in risk aversion across individual investors. There is, however, not an obvious link between risk aversion and the optimal allocation to international assets in a portfolio. Under the CAPM benchmark, with a risk free asset, optimality simply suggests holding the market portfolio and our benchmark idiv is the optimal international equity portfolio. In a 401(k) context, where shorting and leveraging is not possible, the risky frontier may have different international allocations for people with different risk tolerances. For example, high beta foreign investments (such as, currently, emerging markets) may be more prevalent in portfolios of more risk tolerant investors. However, we do not have a direct indicator of risk aversion. Indirectly, the total proportion invested in equities may be an indicator of the risk tolerance of investors and we plan to explore the link between international equity and total equity allocations in future iterations of this article. It is also possible that person-specific characteristics, experience or behavioral biases account for the differences in investment behavior (Cesarini et al., 2009, Campbell et al., 2013, Korniotis and Kumar, 2013).

\section{The Geography of Home Bias}

While personal characteristics explain about $5.5 \%$ of the variation in international allocations, adding zip code fixed effects increases the adjusted $\mathrm{R}^{2}$ to well over $8 \%$. What do these location effects reflect? To examine this, we re-run our benchmark specification, including the salary and account balance variables, but excluding the house value variable, and extract the zip code fixed effects. We then run simple OLS regressions of these zip code effects onto a number of "locational" variables at either the zip code or state level. ${ }^{7}$ Our independent variables can be grouped into three broad themes: wealth, education, and familiarity/information. The first two are really personal characteristics that we can only measure at the zip code level. First, we include the zip code median house value in the regression. Because it substantially reduces our sample size (we only have house values for 8,868 zip codes), we typically run our specifications with and without this variable. Second, it is quite conceivable that education is correlated with financial savvy and perhaps also helps to alleviate any undue apprehension about foreign investments. Fortunately, we have the percentage of the population over 25 years

\footnotetext{
${ }^{7}$ At this point, we simply report OLS standard errors and do not correct for the estimated nature of the zip code effects. Given that we have so many observations, it is unlikely that doing so will materially change the results.
} 
old in each zip code with a high school degree or higher, with a bachelor's degree or higher; or with a master's degree or higher. The summary statistics in Table 6, Panel A, reveal that educational attainment displays substantial variation across zip codes. The $5 \%-95 \%$ range of the distribution is $36.7 \%-81.9 \%$ for a high school degree, $0 \%-32.5 \%$ for a college degree and $0 \%-24.00 \%$ for a master's degree or higher. We also create a financial literacy variable by computing the average performance on the 5 financial knowledge questions in the National Financial Capability survey. These data are only available at the state level.

Finally, most of our other variables can be related to the familiarity/information hypothesis. The first set concerns the percent of the zip code population that is foreign born, for which we do not only have the total, but also the split over Latin America, Europe, Asia and the rest of the world. ${ }^{8}$ These variables also display substantial variation across zip codes, with the $90 \%$ range of total foreign-born population varying between $0 \%$ and $26 \%$. In the international literature, it is common to use distance from foreign markets as a control variable. Such a measure requires knowing the relevant destination countries for most US investments. Given the well-documented international foreign investment biases towards nearby countries, we compute the distance to Toronto and to Mexico; in addition, we compute the distances to London and Tokyo, the financial centers of the two largest investable equity markets in the world outside the US. The summary statistics show the distances in miles, although in the regressions we scale these distances by the average distance for all US zip codes. Our next variable measures whether the employee is living in a metropolitan area, a large rural area, a small rural area or an isolated area, using data from Rural Urban Commuting Area codes (RUCA). It is conceivable that an urban environment enhances familiarity with foreign "things". For the purposes of the summary statistics, we simply coded the variable as going from 1 (metropolitan area) to 4 (isolated), but we use separate dummies in the regression analysis.

Our last set of variables is at the state level. If familiarity plays a large role in international allocations, it is conceivable that the presence of immigrants in a particular area directly or indirectly increases familiarity with foreign culture, products and securities. Familiarity relative to the foreign world can also be enhanced by the work environment, for example through work for a multinational company. We therefore also include two measures of "trade openness," the classic (exports+imports) at the state level divided by state GDP, and the level of exports divided by state GDP, expressed in

\footnotetext{
${ }^{8}$ We also have details on when the immigrants entered the country but defer using that information to future work.
} 
percent. Because the data on imports is less complete than the exports data, most of our analysis uses the exports variable. Again, there is plenty of cross-state variation in these variables, with the $5^{\text {th }}$ percentile of the distribution of state openness being $8.7 \%$ and the $95^{\text {th }}$ percentile being $38.6 \%$. Note that there is a large literature in international finance, starting with Obstfeld and Rogoff (2001) that links home bias in goods to home bias in assets through equilibrium models with transaction costs. However, Van Wincoop and Warnock (2010) show that such a link is empirically rather unlikely. Instead, our motivation to include these variables rests on a familiarity argument. Finally, a more direct measure of potential information flow would be the logarithm of the number of international phone minutes per year per state. Unfortunately these data are not available, and we use long-distance minutes as a proxy. ${ }^{9}$ To measure economic well-being, we include in the analysis GDP per capita and cumulative GDP growth over the five-year period preceding our sample, and over the 2006-2011 period. One useful role of these variables is that they help mitigate concerns that any positive effect of the foreign born population on idiv is due to reverse causality: richer areas are better diversified, and at the same time attract more foreign immigrants.

Before we consider the regressions results, it is worth repeating that in our data set location effects need not be highly correlated with firm effects. While it is true that many employees live close to the place where they work, our sample contains multiple firms with a multitude of branches that are quite spread out geographically.

Table 6, Panel B, reports the regression coefficients for zip code effects extracted from a regression that includes our baseline specification (target date fund, benchmark idiv, trends, and cohort), plus the salary and account balance variables. We verified that the results are robust to using zip code fixed effects derived from a regression with only the baseline variables, which has slightly more observations. The table reports 6 different specifications, but three of those simply add the house value variable to an equivalent specification without the house value variable, which then has many more observations. The first two specifications use coarse indicators of education (\% bachelor's degree or higher), immigration (total percent born abroad) and distance (total distance). The third and fourth specifications are more granular with respect to education (high school, college, higher degree); the origin of the foreign born population, and the distance variable. In the $5^{\text {th }}$ specification we replace the Zillow house values by the ones drawn from the Census, increasing the number of observations considerably. Finally, in the last

\footnotetext{
${ }^{9}$ The data are gathered from the FCC Statistical Trends in Telephony report, see Bekaert, Harvey, Lundblad and Siegel (2013), for more details. The data are spliced with data on inter-state mobile phone minutes.
} 
specification, we take the specification of column (3) and replace the ratio of state exports to GDP with state openness.

The key results can be easily summarized. First, house values do not have a statistically significant effect on zip code variation in international diversification. However, restricting the sample to the Zillow zip codes substantially changes some of the coefficients on the other variables, so in Column (5) we verify the results in Column (4) using house value data from the 2010 Census, which has much bigger coverage. Second, the distance and rural dummies generate results that are economically somewhat difficult to interpret. The overall distance has the expected negative effect on international diversification, but the effect is not statistically significant. When we split this variable up in its components it appears that the distance variables have the expected negative sign and the effect is statistically quite significant for most of them. The only exception is column (4), which is based on the smaller Zillow house value, suggesting that the reason for the difference is the smaller sample size. For long distance minutes, we find an unexpected negative effect for the large sample, but a positive effect for the smaller sample. Finally, we find a lower international diversification in both urban and larger rural areas (versus isolated areas as the benchmark). Further (not reported) analysis which includes only urban, rural and isolated dummies generates a positive and strongly statistically significant coefficient for urban, indicating that the reason for the difference is due to other controls, like foreign born, education and financial literacy being strongly correlated with the urban dummy.

Third, the GDP growth variables do not have a significant effect on international diversification for the large samples, but do, and more so for contemporaneous growth, for the small sample. On the contrary, GDP per capita at the state level has a robust, albeit economically small, negative effect on international diversification.

Fourth, we find a highly significant effect of education levels on international allocations. To get a sense of the economic variation the coefficients imply, consider evaluating the regression coefficients at the $90 \%$ range of the distribution reported in Panel A of Table 6. We use the coefficients from the base specification without the house values, but note that the coefficients are larger in both specifications with house values (columns (2) and (5)). For a high school degree, the international allocation is predicted to change over this range by about $1.67 \%(0.037 *(81.9-36.7)$; for a college degree, by about $2.21 \%$ $(.068 * 32.5)$ and for a higher degree by about $1.61 \%(0.067 * 24.0)$. Cumulatively, the effect is about $5.5 \%$. We also examine financial literacy directly, and this variable has a coefficient varying between 1.81 and 3.5, significant at the $1 \%$ level, in the large sample 
and looses statistical significance in the smaller Zillow sample, which may have limited the cross-zip code variation in the data. The financial literacy variable reflects the average score on 5 financial knowledge questions so that the large coefficient implies a substantial economic effect of financial literacy. Even considering a $90 \%$ range of only 0.4 , going from poor to high financial literacy amounts to a $1.4 \%$ increase in international diversification. We should also note that general education is already controlled for, so that improving financial literacy per se has the potential to greatly increase international diversification outcomes.

Fifth, we also observe a substantial "foreign born" effect with a coefficient around 0.03 , statistically significant at the $1 \%$ level in all specifications. Economically, in this case, given that the foreign population varies between $0 \%$ and $26 \%$, the $90 \%$ range would be a $0.78 \%$ effect. When we look at the origin of the immigration, we find that all the variables, except for the "other" category, are statistically significant, with the European variable having the highest coefficient. However, the European immigration percentages are also lowest among the three groups and the economic effect of immigration is larger for the Latin-American group.

Finally, trade openness only generates strong and consistent results when measured using exports. We obtain a consistently positive sign and strong statistical significance. The $90 \%$ range for this variable, which is $11.1 \%$, would induce about a $1 \%$ increase in international diversification. When we replace state exports to GDP with the state openness measure based on both imports and exports, we find an equally statistically significant but economically smaller effect, with the $90 \%$ range implying an increase international diversification of about $0.6 \%$.

We conclude that there are relatively strong locational effects in international equity allocations, related to education, immigration and exports.

\section{Firm Characteristics and International Diversification}

Firm fixed effects substantially increase the adjusted $\mathrm{R}^{2}$ in the regressions we have run so far (See Table 3). Because we examine the international allocations in 401(k) plans, the quality of the plan offered is perhaps the most obvious determinant of variation in international allocations across firms. In the worst case scenario, a particular plan may not even have an international mutual fund option, as, to our knowledge, it is not strictly required by the Department of Labor legislation on the minimum requirements for 
diversification in 401(k) plans. Alternatively, the options may be limited and/or have exorbitant fees, making international diversification ultimately not optimal. Given the policy relevance of this issue, we are currently collecting detailed information on actual plans, including the number of international funds, fees, the presence or absence of (international) index funds, potentially supplemented with proprietary estimates of forward looking alphas for the international funds. Unfortunately, we must defer analyzing these data to future work.

Instead, we conduct a preliminary analysis of the association between the international allocations and firm characteristics. A first set of characteristics attempts to measure how "international" a firm is, either directly or indirectly. A firm's culture or the firm's activities may make their employees more familiar and comfortable with investing internationally. We collect information from CapitalIQ on the ultimate parent and the country of the ultimate parent (for private and public firms) of the company. Using this information, we can create a dummy that is equal to 1 if the ultimate parent is foreign. About $16 \%$ of the firms in our sample have a foreign parent (see the summary statistics in Table 7, Panel A). We also quantify whether the firm has foreign subsidiaries, using information from Orbis. We create a dummy variable that is equal to 1 if the firm has foreign subsidiaries, and we also code a variable that simply equals the fraction of subsidiaries that is foreign. As Table 7 (Panel A) shows, 56\% of our firms have at least one foreign. The cross-firm variation in the fraction of foreign subsidiaries is vast, varying between 0 and $87.3 \%$. A firm's activities may also make it more or less "foreign." We therefore examine the openness ((imports+exports)/output) of the industry to which the firm belongs. ${ }^{10}$

We supplement these variables with a number of variables measuring different firm characteristics, most of which do not have clear ex-ante testable hypotheses associated with them. First, we include a dummy to indicate whether the firm is private or publicly traded. Second, we include two measures of size, the logarithm of the assets and the logarithm of the number of employees. We conjecture that employees at public and large firms may be more likely to be familiar with foreign investments, or they may have more elaborate and diverse 401(k) plans with more and better international options. We also use a leverage measure (debt/assets) and sales intensity measure (sales/assets). Third, we include measures of profitability (net income as a percent of assets) and investment intensity (capital expenditures as a percent of assets). Fourth, we include the logarithm of the age of the firm, where the logarithmic transformation is necessary because some firms

\footnotetext{
${ }^{10}$ In the next iteration, we will also examine the financial and economic openness of the industry using the measure described in Bekaert, Harvey, Lundblad and Siegel (2011).
} 
in our sample are very old. Finally, we show statistics regarding the 401(k) plans firms offer, either the total plan size, or the average plan size per firm (some firms have more than one plan). Table 7, Panel A, also reports summary statistics regarding these firm characteristics.

While we have panel data for some of these variables, we run an exploratory analysis on the firm fixed effects. Given our short sample, we simply average the independent variables. Again, we used both the baseline specification (target date fund allocation, idiv benchmark, trend variables, and cohort variable), and the baseline specification with the salary and wealth variables (baseline + quadratic salaries + quadratic account balances + linear house values), but we will report the results for fixed effects extracted from the more elaborate specification. We then examine 7 different regression specifications. The first two regressions eliminate the firm characteristics from the analysis, as they halve the size of our sample. They differ in their use of either the foreign subsidiary dummy or the fraction of foreign subsidiaries. Even though the private dummy is the only statistically significant variable, the $\mathrm{R}^{2}$ of these regressions is relatively high at $11 \%$. Yet, at least for this sample, the variables measuring the international nature of the firm do not have a significant effect on international allocations. Note, that, unexpectedly, the private company dummy has a strong and positive effect on the international allocation. It turns out that $23 \%$ of the private firms have a foreign headquarter, but only $4.5 \%$ of the public firms do.

In the remaining regressions, we add firm characteristics such as size, age, profitability etc. The regression in Column (3) only has firm characteristics, whereas the regressions in columns (4) and (5) add firm characteristics to the specifications in Columns (1) and (2). Our sample now loses about 100 firms for which not all the data are available; most of these firms are private firms. We now observe a few significant relationships. The private firm dummy remains significant and positive. The foreign subsidiary dummy now gets a positive and economically large coefficient, indicating that having foreign subsidiaries increases international allocations by about $2.5 \%$, controlling for other firm characteristics. However, while the t-statistic is solidly above 1.50 , it does not reach statistical significance at the $10 \%$ level. Of the firm characteristics, the only significant coefficient is for the profitability variable. More profitable firms feature lower international allocations, although the economic effect seems small. One possibility is that workers in profitable firms invest disproportionally in company stock, crowding out international investments. To examine this substitution effect further, we calculated the aggregate allocation to company stock at the firm level. That is, we take the last observation on company allocations per individual in each year and multiply this 
allocation by the total account value to obtain a dollar allocation and aggregate this over each firm-year. We then match firm-year aggregate company allocations to firm-year profitability, leading to 513 observations for profitability and company stock allocations. We do find a positive but small correlation between the two variables, at $10.9 \%$, significant at the $1 \%$ level.

Finally, in regressions (6) and (7), we add either total plan size, or average plan size to the set of independent variables. The profitability and private dummy variables remain significant with the same coefficients as before. The total plan size variable gets a negative coefficient, significant at the $10 \%$ level, indicating that firms with larger plans tend to have workers with lower international allocations.

\section{Robustness Checks}

While we have already reported on a number of robustness checks along the way, here we specifically focus on the problem that our data represent one 401(k) account per person, which may not be representative of the full portfolio of the individual.

To investigate this issue, we focus on sub-samples of individuals for whom there is a high chance that their wealth is dominated by their $401(\mathrm{k})$ account and that this $401(\mathrm{k})$ account is their only account. Of course, our selection criteria will use variables that are themselves correlated with international diversification. While this is not desirable, it would make finding robust results all the more surprising.

Our first criteria simply use tenure and age, and is based on the fact that relatively old workers with a relatively low tenure at the firm are more likely to already have a 401(k) account from a previous employer, or to have an IRA account. Having examined the joint distribution of age and tenure, our exclusion criteria are as follows:

For workers with tenure between 0 to 3 years, we exclude people of age 36 or older;

For workers with tenure between 4 to 5 years, we exclude people of age 41 or older;

For workers with tenure between 6 to 10 years, we exclude people of age 46 or older;

For workers with tenure between 11 to 15 years, we exclude people of age 51 or older;

For workers with tenure between 16 to 20 years, we exclude people of age 56 or older. 
This is the age/tenure sub-sample. In the base line specification, this sample still has close to 6 million observations. We also create a sub-sample based on salary and account value, excluding individuals with a salary of above 100,000 USD or an account balance of over 200,000 USD. Such individuals are likely to have substantial taxable assets, making their $401(\mathrm{k})$ account less representative of their overall allocation. This sample has over 10 million observations. Finally, we create a sub-sample combining both criteria, which reduces the sample size to about 4 million observations.

In Table 8, we show these results in columns (2) through (4), in two panels. In Panel A, we focus on the benchmark specification with only the target date fund variable, the idiv benchmark, trends and cohorts. In Panel B, we add salary, account balances and house values. In the first column, we repeat the benchmark result, reported for convenience. Focusing first on Panel A, we can see that the cohort effect is very robust with the coefficients only varying between 0.16 and 0.19 . The target date fund variables and international diversification benchmark remain statistically significant in all specifications, but the coefficients vary slightly more. The trend coefficients are less robust in terms of magnitude. These results carry over to Panel B. There, the salary effect weakens with the smaller samples with the level effect even becoming insignificant in the most restricted sample (in column (4)). The account value coefficients vary less, and remain significant in all specifications. The effect of house value on international diversification remains significant and positive, the coefficient merely dropping by about 0.10-0.15.

We also investigate the bond allocation for our accounts. A high allocation to bonds may indicate an asset location strategy and suggest a sizable taxable portfolio. The mean allocation to bonds (conditional on equity market participation) is $18.7 \%$, with the $90 \%$ range going from $0 \%$ to $52 \%$. As we explained before, our focus on idiv (foreign equity over total equity) implies that high bond allocations may not necessarily be a problem. However, to increase the representativeness of the sample, we also investigate a sample excluding accounts with bond allocations of over 50\%. This removes 1,172,576 observations from the sample. Note that accounts without any equity are already not being considered. Again, Column (5) in Table 8 (both Panels A and B) shows the results to be quite robust, even for the trend coefficients.

By focusing on the relative equity allocation, we were able to not confuse stock market participation biases with international under-diversification. Yet, it is also of interest to investigate overall international allocations. Unfortunately, we do not observe the allocation to international bonds, although we surmise it is relatively small. The last 
column of Table 8 (specification (6)) reports results where we change the left hand side variable to the proportion of overall assets that is invested internationally. This increases the sample considerably, as portfolios with zero equity holdings are now included. Yet, the main results remain largely intact. The cohort, international benchmark and target date fund effects all become slightly larger, but the salary and account value coefficients become smaller in absolute magnitude.

Finally, since we do not observe the actual holdings of our investors, it is possible that some may hold US portfolios (stocks) that have more exposure to international factors (e.g. multinationals), see Cai and Warnock (2012). Yet, both old research by Jaquillat and Solnik (1978) and newer results by Rowland and Tesar (2004) suggest that multinationals do not suffice to span the international diversification benefits from investing in local foreign companies. However, for this to be a problem we should see investors use multinational companies as a substitute for international investments. While we do not have information on multinational investments, our data set does split up the US portfolio in small and large companies. Presumably, multinational companies tend to be large. When we correlate the international equity allocation with the allocation to large US equities, we actually find it to be positive at $12.7 \%$. It is therefore unlikely investors use large US companies as substitutes for international diversification.

\section{Conclusions}

We have examined the international equity allocations of over 3 million individuals in $296401(\mathrm{k})$ plans over the 2006-2011 period. A striking feature of the data is the enormous cross-individual variation in these allocations, with non-negligible fractions of individuals allocating zero but a minority also allocating more than $75 \%$ of their equity portfolio internationally. We examine four sources of variation in these allocations: pure temporal variation, personal characteristics, location effects and firm effects. We find that there is an upward trend in international allocations that is only partially accounted for by the slight decrease in importance of the US market relative to the world market. There is a strong cohort effect, with younger cohorts investing more internationally, but each cohort also investing more internationally over time. This finding suggests that the home bias phenomenon may slowly disappear over time. We also find a positive salary and a negative account balance effect, but these effects are not economically large. The level of education measured at the zip code level has a strong positive effect on international diversification, as does financial literacy. Moreover, the presence of foreign-born people at the zip code level also strongly increases international allocations. 
In addition, states with more exports have higher international allocations. At the firm level, we find that private companies have higher while profitable firms have lower international allocations. A number of our results are consistent with the familiarity hypothesis stressed in the international finance literature, including the cohort effect, which may stem from globalization making younger people more comfortable with international investing. However, there are clearly other forces at work as well and we only explain a small part of the total cross-individual variation. All of our regressions include a target date fund dummy, which is always highly significant. We predict that plan features, which we are currently collecting, will also have strong explanatory power. Together with the strong effect of education, there clearly is a role for public policy to correct individual investment mistakes, which may be very important for retirement outcomes.

Because we only have data on the 401(k) allocations, which for many individuals may not represent their full investment portfolio, it is conceivable that some people underinvest in international equity in their 401(k) plan, but have international allocations elsewhere. Taking taxes into account, asset location optimization would suggest skewing the 401(k) portfolio towards bonds. We accommodate this critique partially by focusing on the relative equity allocation. In addition, we have examined various samples that minimize the incomplete portfolio problem, excluding people with very low tenure but high age, and/or account balances and/or a salary that is relatively high. We also investigate a sample excluding accounts with excessive bond allocations, which may also suggest an asset location strategy. Our results remain robust in all of these sub-samples.

So far, we have studied the international equity allocation, conditional on equity market participation. It may also be interesting to study the decision to participate in the international equity market by itself, as some 5 million of our totally available observations record a zero international allocation. While these observations are partly correlated with general stock market non-participation, this correlation is not perfect. One possibility is that this behavior is heavily correlated with other behavioral investment biases/mistakes, such as excessive allocations to money market instruments and/or to company stock. We defer analyzing this to future work.

Our results have important implications for the international finance literature on home bias. First, many of our results do confirm the importance of familiarity and information flow stories (Andrade and Chhaochharia, 2010; Van Nieuwerburgh and Veldkamp, 2009), which must be researched in more detail. Second, the large cross-individual variation linked to factors such as cohorts and education should lead to additional 
analysis of cross-country home bias, away from aggregate factors, such as corporate governance and stock market development. In fact, our results suggest that the age distribution may help explain cross-country patterns in home bias, which hitherto has never been examined. Finally, recent research suggests an important role for cultural factors, such as masculinity and long-term orientation, in driving the extent of home bias (Anderson, Fedonia, Hirschey, Skiba, 2010). It is possible that such factors can help explain cross-individual differences in home bias. However, we only observe this information at the aggregate level. Unless there exist large differences in culture across the different states, such factors cannot account for the observed dispersion.

\section{References}

Ahearne, A. G., W. L. Griever and F. E. Warnock, 2004, "Information costs and home bias: an analysis of U.S. holdings of foreign equities", Journal of International Economics, 62, 313-336.

Ameriks, J. and S. Zeldes, 2004, "How Do Household Portfolio Shares Vary with Age?", Working Paper.

Anderson, C. M. Fedenia, M. Hirschey, and H. Skiba, 2010 "Cultural Influences on Home Bias and International Diversification by Institutional Investors", Working Paper.

Andrade, S., and V. Chhaochharia, 2010, "Information immobility and foreign portfolio investment," Review of Financial Studies, 23, 2429-2463.

Aviat, A. and N. Coeurdacier, 2007, "The geography of trade in goods and asset holdings", Journal of International Economics, 71, 22-51.

Baele, L., Bekaert, G., Inghelbrecht, K., Wei, M, 2013, "Flights to Safety”, Working Paper.

Bailey, W., and L. Ng, "Foreign Investment of US individual investors: Causes and consequences," Management Science.

Barnea, A., Cronqvist, H., Siegel, S, 2010, "Nature or nurture: What determines investor behavior?", Journal of Financial Economics, 98, 583-604.

Becker, S.O., and M. Hoffmann, 2010, "Equity fund ownership and the cross-regional diversification of household risk," Journal of Banking \& Finance, 34, 1, 90-102. 
Bekaert, G., S. Siegel and X. Wang, 2013, “Home Bias Revisited,” Working Paper.

Bekaert, G., C. R. Harvey, C. Lundblad, and S. Siegel, 2011, "What Segments Equity Markets?” Review of Financial Studies, 24, 12, 3847-3890.

Bekaert, G., C. R. Harvey, C. Lundblad, and S. Siegel, 2013, "Stock Market Valuation across US States," work in progress.

Bohn, H., and L. Tesar, 1996, "U.S. Equity investment in foreign markets: portfolio rebalancing or return chasing?," American Economic Review: Papers and Proceedings, 77-81.

Brennan, M. J. and H. H. Cao, 1997, "International portfolio investment flows", Journal of Finance, 52, 1851-1880.

Cai, F. and F.E. Warnock, 2012, "Foreign exposure through domestic equities," Finance Research Letters, 8-20.

Calvet, L., J. Campbell, and P. Sodini, 2007, "Down or Out: Assessing the Welfare Cost of Household Investment Mistakes", Journal of Political Economy, 115(5), 707-747.

Calvet, L., Campbell, J., P. Sodini, 2009, "Fight or Flight? Portfolio Rebalancing by Individual Investors," Quarterly Journal of Economics, 124, 301-348.

Calvet, L., J. Campbell, and P. Sodini, 2010, "Measuring the Financial Sophistication of Households", American Economic Review, P\&P,

Campbell, J. Y., T. Ramadorai, and B. Ranish, 2013, "Getting Better: Learning to Invest in an Emerging Stock Market", Working Paper.

Cesarini, D., C. T. Dawes, M. Johannesson, P. Lichtenstein, and B. Wallace, 2009, "Genetic variation in preferences for giving and risk taking," Quarterly Journal of Economics, 124, 809-842.

Chan, K., V. Covrig and L. Ng, 2005, "What determines the domestic bias and foreign bias? Evidence from mutual fund equity allocations worldwide", The Journal of Finance, 60, 1495-1534.

Cooper, J. and E. Kaplanis, 1994, "Home bias in Equity portfolios, inflation hedging and international capital market equilibrium," Review of Financial Studies. 
Coval, J. and T. Moskowitz, 1999, "Home Bias at Home: Local Equity Preferences in Domestic Portfolios”, Journal of Finance, 54, 2045- 2073.

Coval, J., and T. Moskowitz, 2001, "The Geography of Investment: Informed Trading and Asset Prices", Journal of Political Economy, 109, 811-841.

Curcuru, Stephanie, John Heaton, Deborah Lucas, and Damien Moore, "Heterogeneity and Portfolio Choice: Theory and Evidence," in Handbook of Financial Econometrics, ed.:

Dahlquist, M., L. Pinkowitz, R. M. Stulz and R. Williamson, 2003, "Corporate governance and home bias”, Journal of Financial and Quantitative Analysis, 38, 87-110.

Duflo, E., W. Gale, J. Liebman, P. Orszag, and E. Saez, 2006, "Saving Incentives for Low- and Middle-Income Families: Evidence from a Field Experiment with H\&R Block", Quarterly Journal of Economics, 121(4), 1311-1346.

Edwin J. Elton, Martin J. Gruber, and Christopher R. Blake, 2006, "The Adequacy of Investment Choices Offered By 401(k) Plans", Journal of Public Economics. Vol. 90, Issue 6-7, pp 1299-1314.

Fidora, M., M. Fratzscher and C. Thimann, 2007, "Home bias in global bond and equity markets: The role of real exchange rate volatility", Journal of International Money and Finance, 26, 631-655.

French, K., and J. Poterba "International diversification and international equity markets," American Economic Review.

Glassman, D. A. and L. A. Riddick, 2001, "What causes home asset bias and how should it be measured?" Journal of Empirical Finance, 8, 35-54.

Graham, J., Harvey, C., Huang, H, 2009, "Investor Competence, Trading Frequency and Home Bias,” Management Science, INFORMS, 55(7), 1094-1106.

Grinblatt, M. and M. Keloharju, 2001, "How Distance, Language and Culture Influence Stock Holdings and Trades", The Journal of Finance, 56, 3, 1053-1073.

Grinblatt, M. and M. Keloharju, 2001, "What Makes Investors Trade?" The Journal of Finance, 56 (2), 589-616.

Huang, J., 2008, “Taxable and Tax Deferred Investing: An Arbitrage Approach,” Review of Financial Studies, 21, 2173-2207. 
Huberman, G., 2001, "Familiarity breeds investment", Review of Financial Studies, 14, 659-680.

Jacquillat, B. and B.H. Solnik, 1978, "Multinationals are poor tools for diversification," Journal of Portfolio Management, 4, 8-12.

Kang, JK and R. Stulz, 1997, "Why is there a home bias? An analysis of foreign portfolio equity ownership in Japan," Journal of Financial Economics, 46(1), 3-28.

Karlsson, A. and L. Norden, 2007, "Home sweet home: Home bias and international diversification among individual investors," Journal of Banking and Finance, 31, 2, 317333.

Kézdi, G., 2004, "Robust standard error estimation in fixed-effects panel models," Hungarian Statistical Review, Special English Volume \#9, 95-116.

Kho, B., Stulz, and Warnock, F, 2009, "Financial Globalization, Governance and the Evolution of the Home Bias," Journal of Accounting Research, 47 (2), 597-635.

Korniotis , G., and A. Kumar, 2013, "Do Portfolio Distortions Reflect Superior Information or Psychological Biases?, Journal of Financial and Quantitative Analysis, $48(1), 1-45$.

Lewis, K, 1999, "Trying to Explain Home Bias in Equities and Consumption," Journal of Economic Literature, 37(2), 571-608.

Madrian, B. and Shea, D, 2001, "The Power of Suggestion: Inertia in 401(k)

Participation and Savings Behavior," Quarterly Journal of Economics, 116(4), 11491187.

Malmendier, U. and S. Nagel, 2011, "Depression Babies: Do Macroeconomics Experiences Affect Risk-Taking? Quarterly Journal of Economics, 126(1), 373-416.

Norden, Lars, 2010, "Individual Home Bias, Portfolio Churning and Performance", European Journal of Finance, 16(4), p. 329-351.

Portes, R. and H. Rey, 2005, "The determinant of cross-border equity flows", Journal of International Economics, 65, 269-296.

Rowland, P. and L. Tesar, 2004, "Multinationals and the Gains from International Diversification," Review of Economic Dynamics, 7, 789-826. 
Sercu, P. and Vanpee, R, 2012, “The home bias puzzle in equity portfolios", International Finance: A Survey, 310-331.

Sharpe, W.F., 1992, “Asset allocation: Management style and performance measurement", Journal of Portfolio Management, 7-19.

Van Nieuwerburgh, S. and L. Veldkamp, 2009, "Information Immobility and the Home Bias Puzzle", Journal of Finance, vol. 64(3), 1187-1215.

Van Wincoop, Eric, and Francis E. Warnock, 2010, "Is Home Bias in Assets Related to Home Bias in Goods?” Journal of International Money and Finance 29: 1108-1123. 
Figure 1

International Diversification across Individuals

Panel A shows a histogram with the distribution of international equity allocations as a percent of total equity allocations across individuals' 401(k) portfolios. The figure in Panel B shows the distribution of this ratio relative to an international diversification benchmark. The sample in both figures is restricted to stock market participants (individuals with positive total equity allocations). All variables are defined in the Appendix.

\section{Panel A - International Diversification}

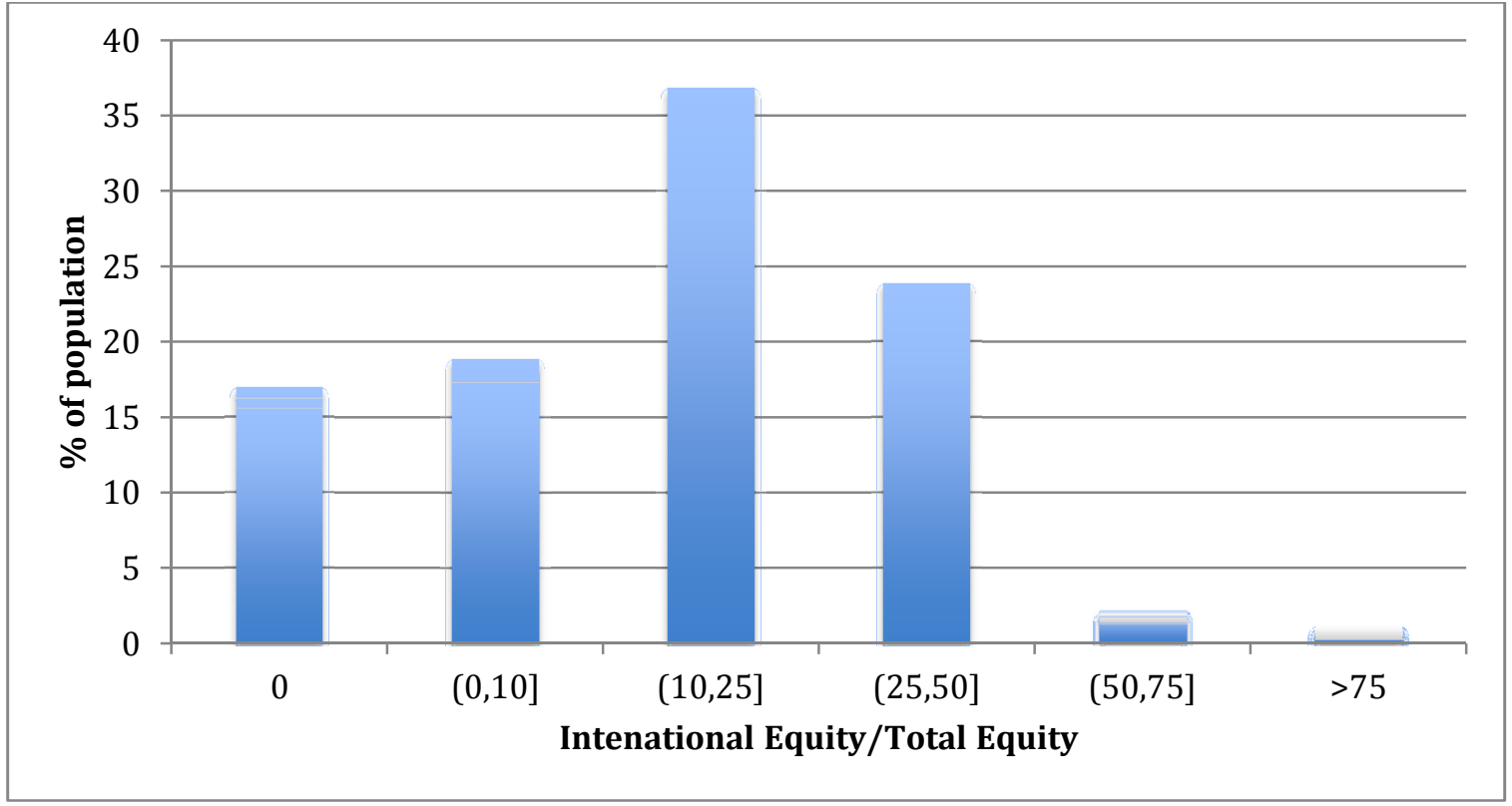

\section{Panel B - Over and Under International Diversification}

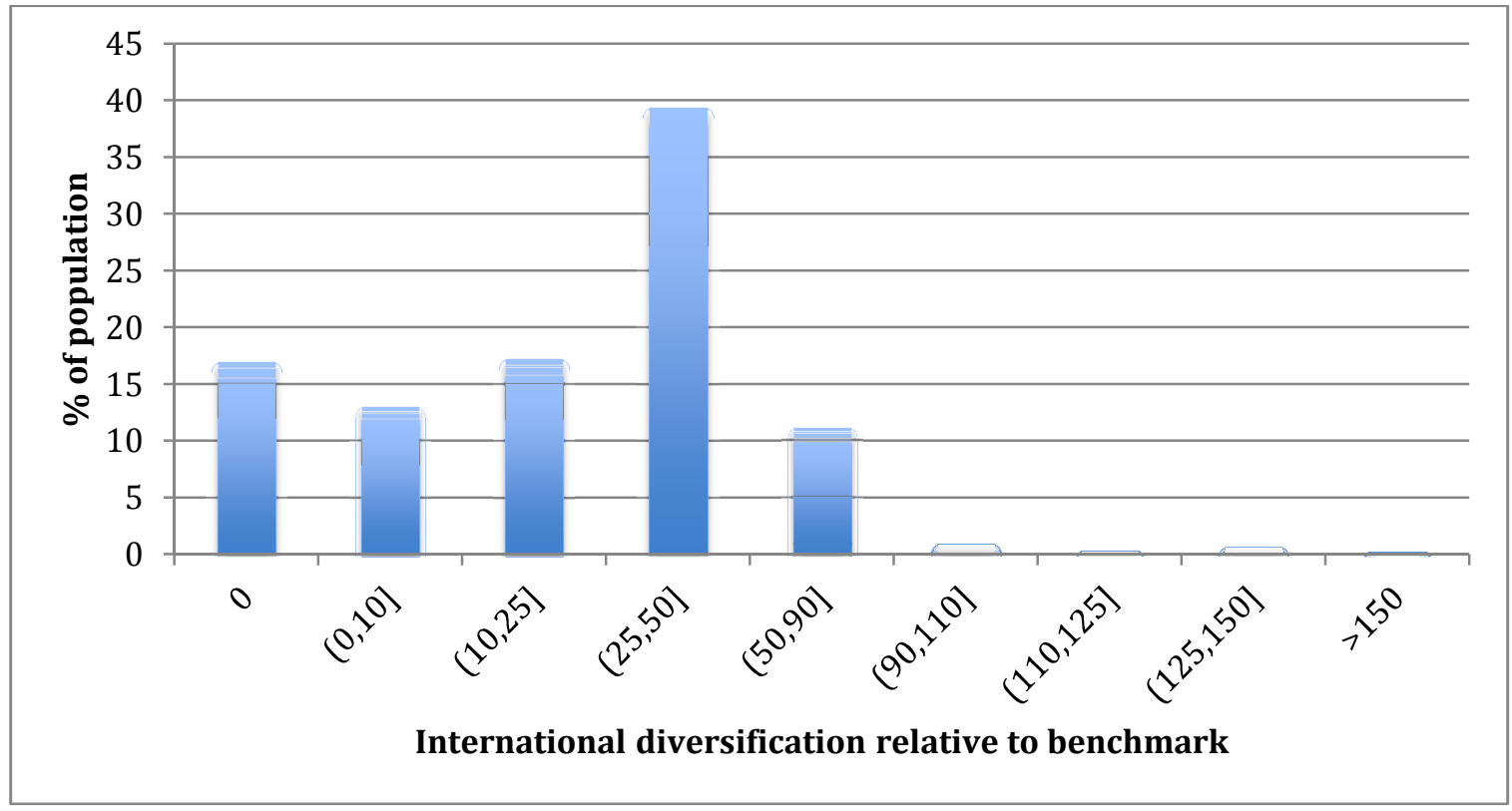


Figure 2

International Diversification across States

Figure 2 shows maps with the distribution of international equity allocations as a percent of total equity allocations across states at different points in time. State data averages ratios across individuals' 401(k) portfolios according to the zip code in which they reside.

\section{Panel A - International Diversification across States in 2007}

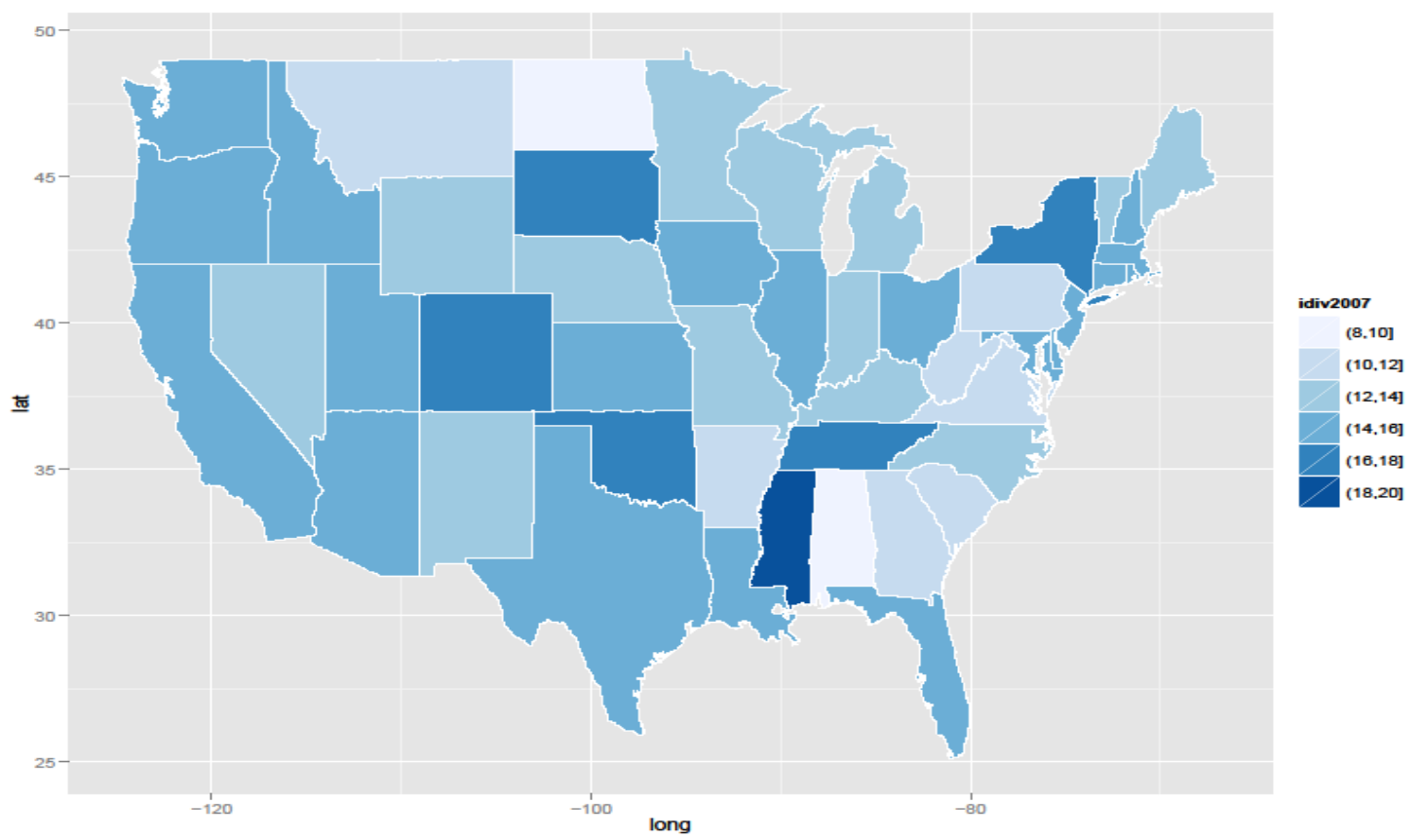

Panel B - International Diversification across States in 2010

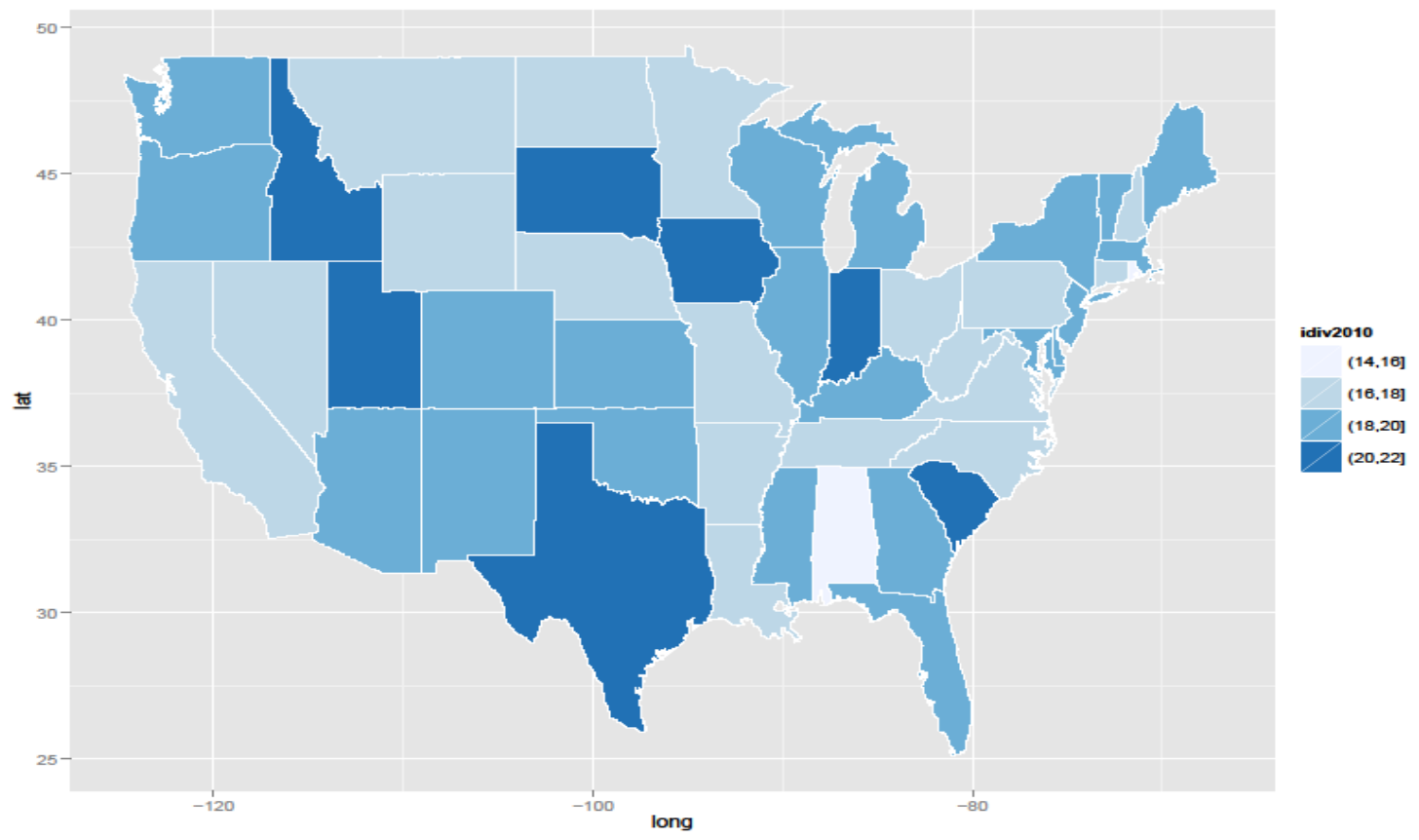


Figure 3

International Diversification across Firms

Panel A shows a histogram with the distribution of international equity allocations as a percent of total equity allocations across firms. The figure in Panel B shows the distribution of this ratio relative to an international diversification benchmark. The sample in both figures is restricted to stock market participants (individuals with positive total equity allocations). Firm data averages ratios across employees' 401(k) portfolios. All variables are defined in the Appendix.

\section{Panel A - International Diversification}

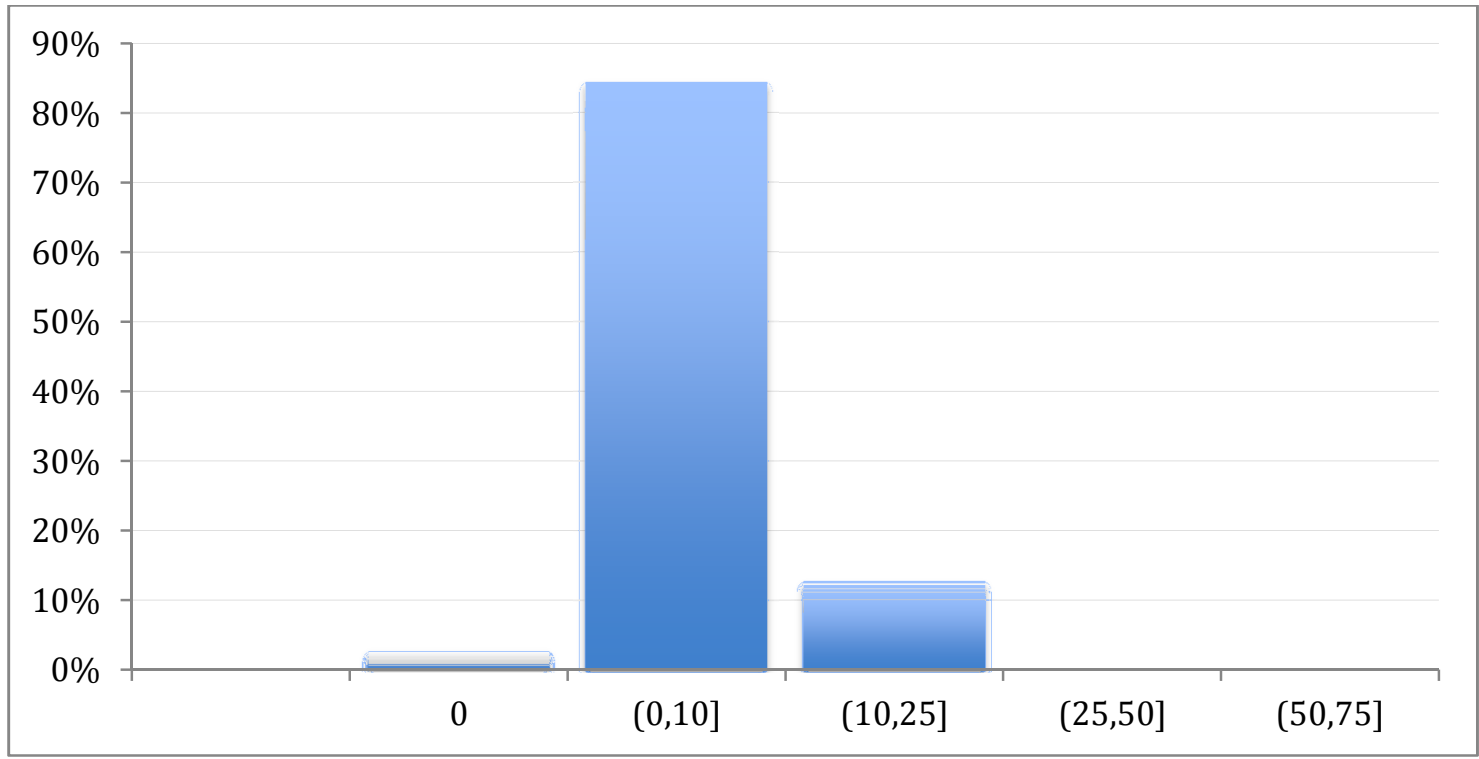

\section{Panel B - Over and Under International Diversification}

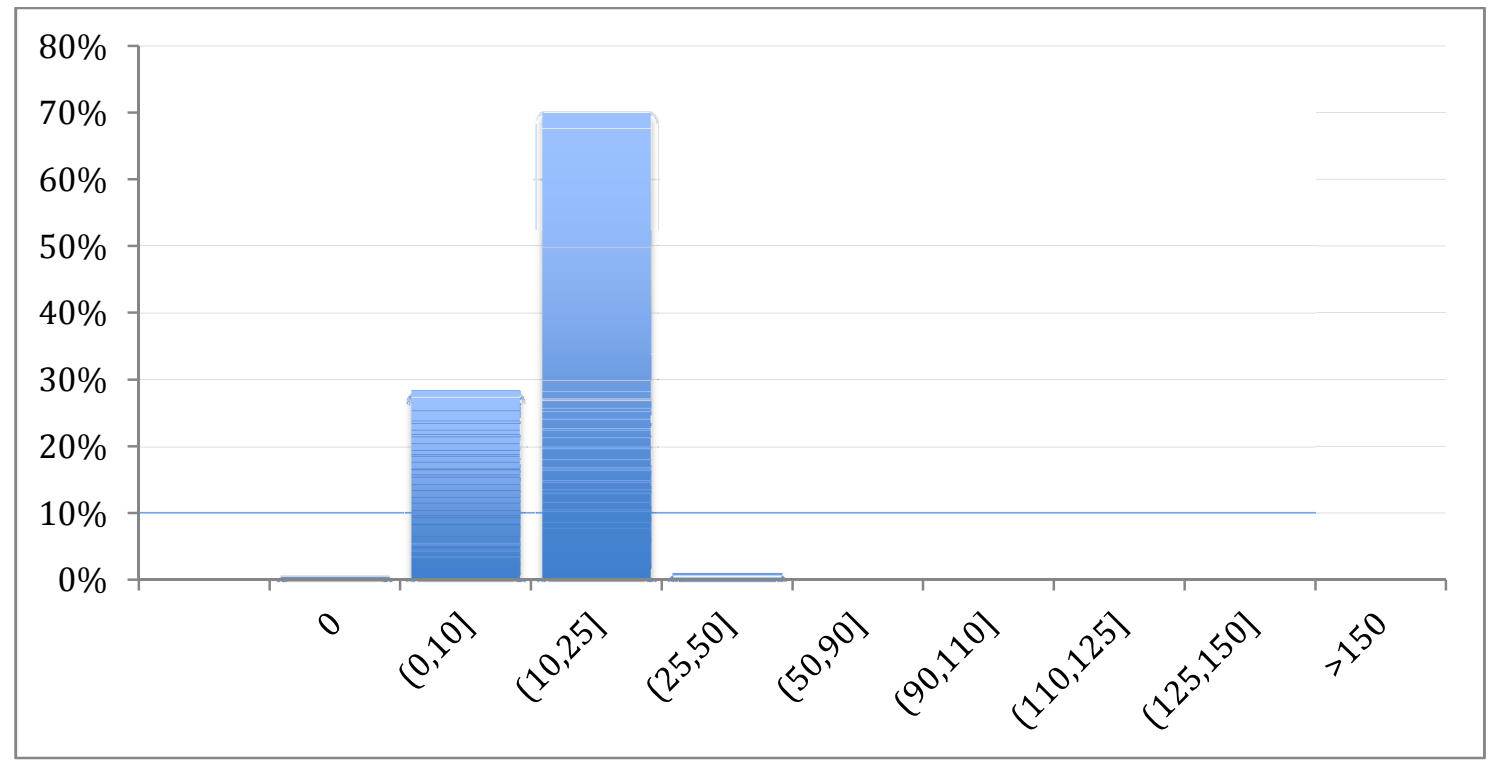


Figure 4

\section{International Diversification over Time}

Panel A shows the time fixed effects from an individual level regression of international diversification on quarterly time dummy variables. Panel B plots the same time effects together with the international diversification benchmark. Panel $\mathrm{C}$ shows the time fixed effects from an individual level regression of relative international diversification (the ratio of international diversification to the benchmark) on quarterly time dummy variables. The sample in all figures is restricted to stock market participants (individuals with positive total equity allocations). All variables are defined in the Appendix.

\section{Panel A: Trends in International Diversification}

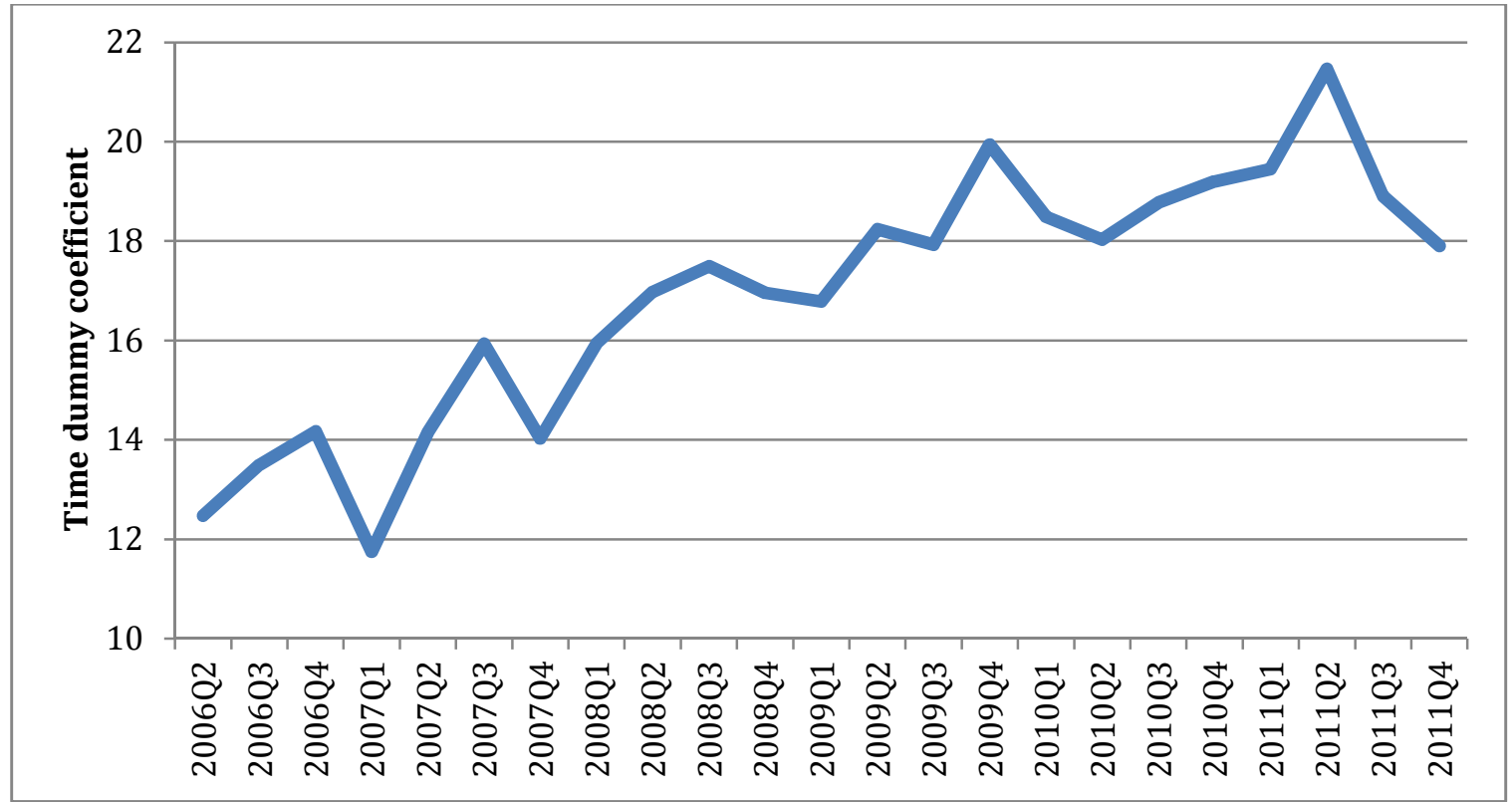

\section{Panel B: International Diversification versus Benchmark}

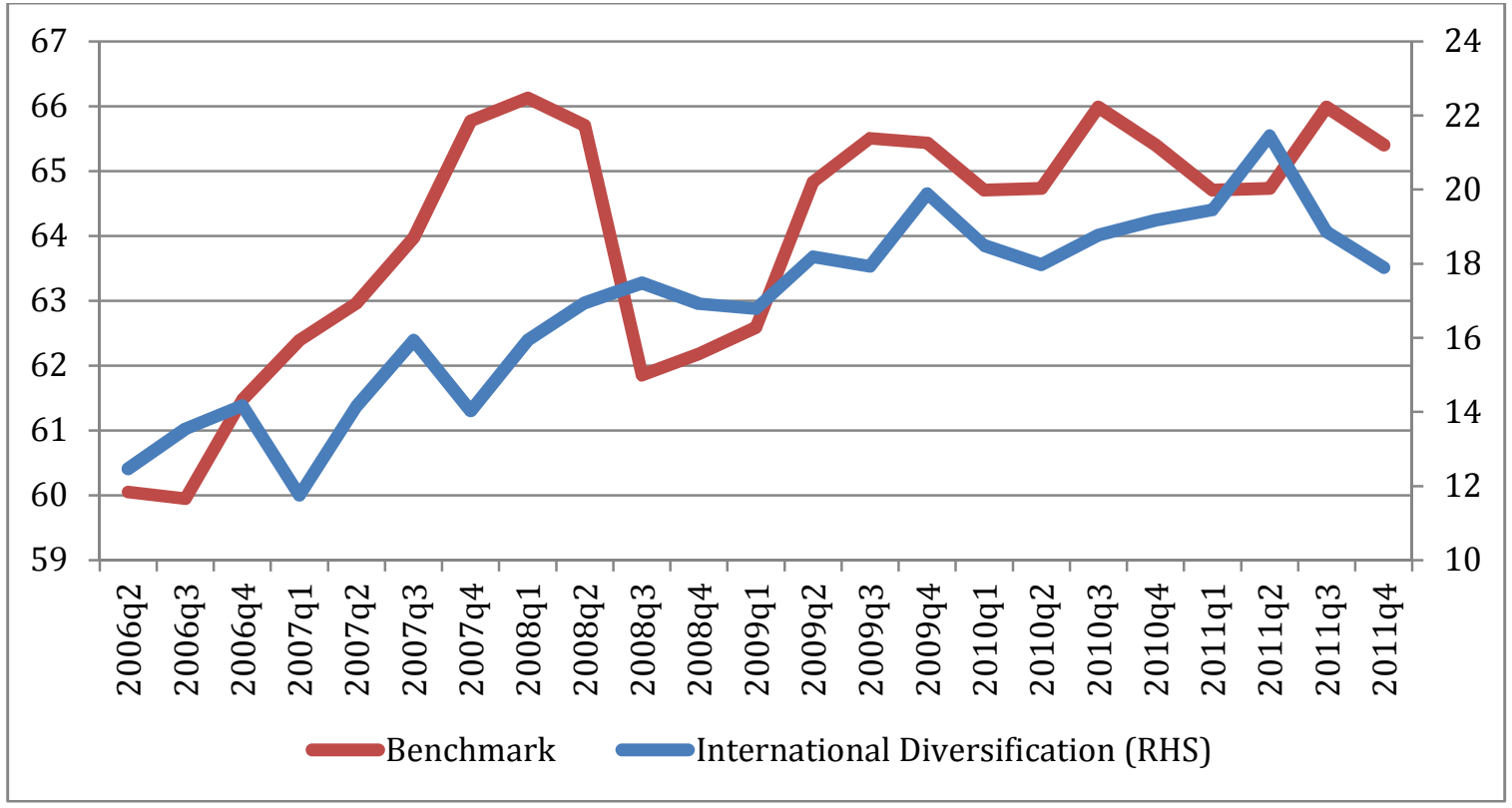




\section{Panel C: Trends in Relative International Diversification}

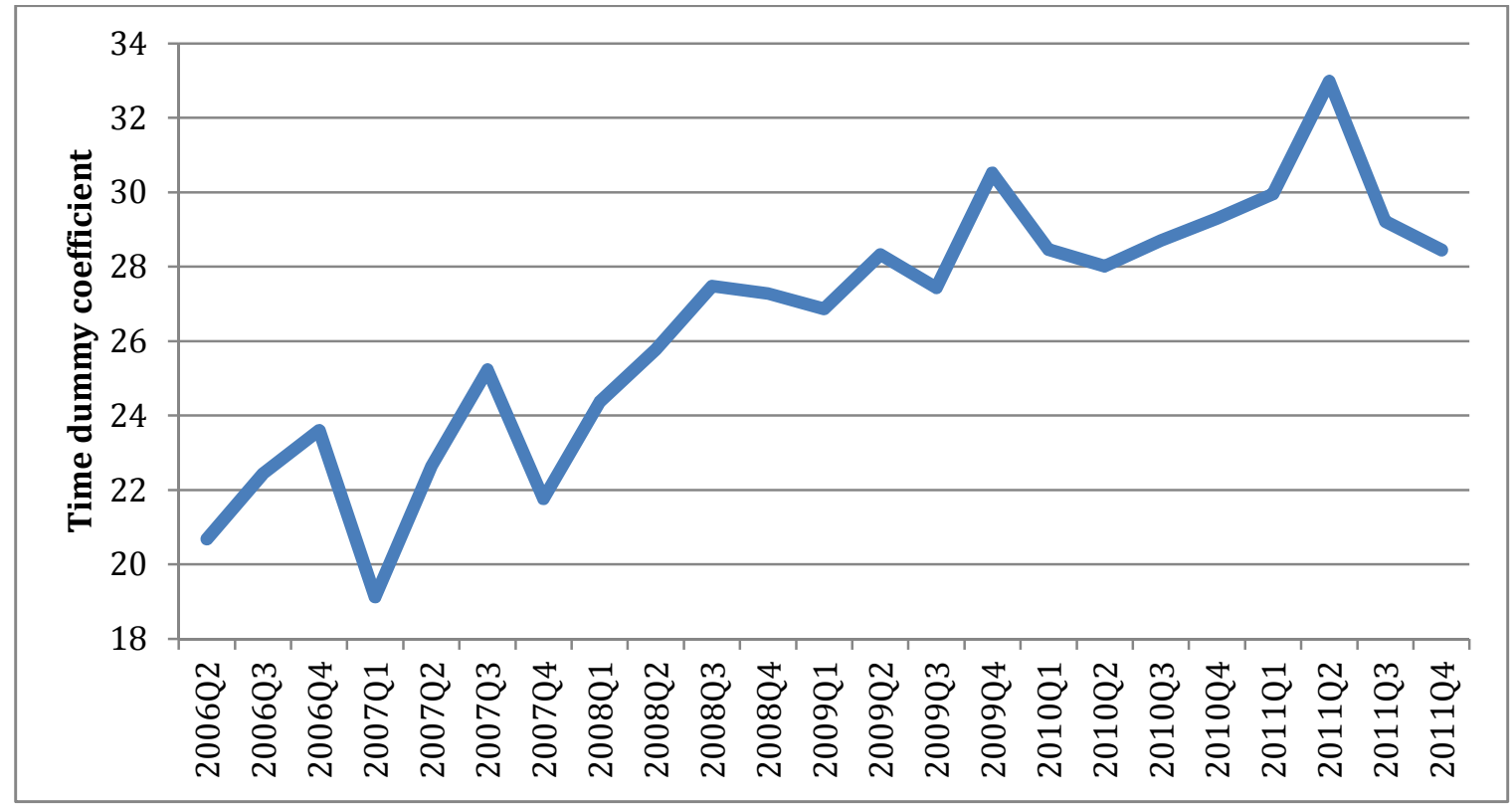

Figure 5

Cohorts and International Diversification

The graph shows international diversification allocations over time by cohort group (people born before 1950, between 1950 and 1959, between 1960 and 1969, between 1970 and 1979 and 1980 or later). The sample is restricted to stock market participants (individuals with positive total equity allocations).

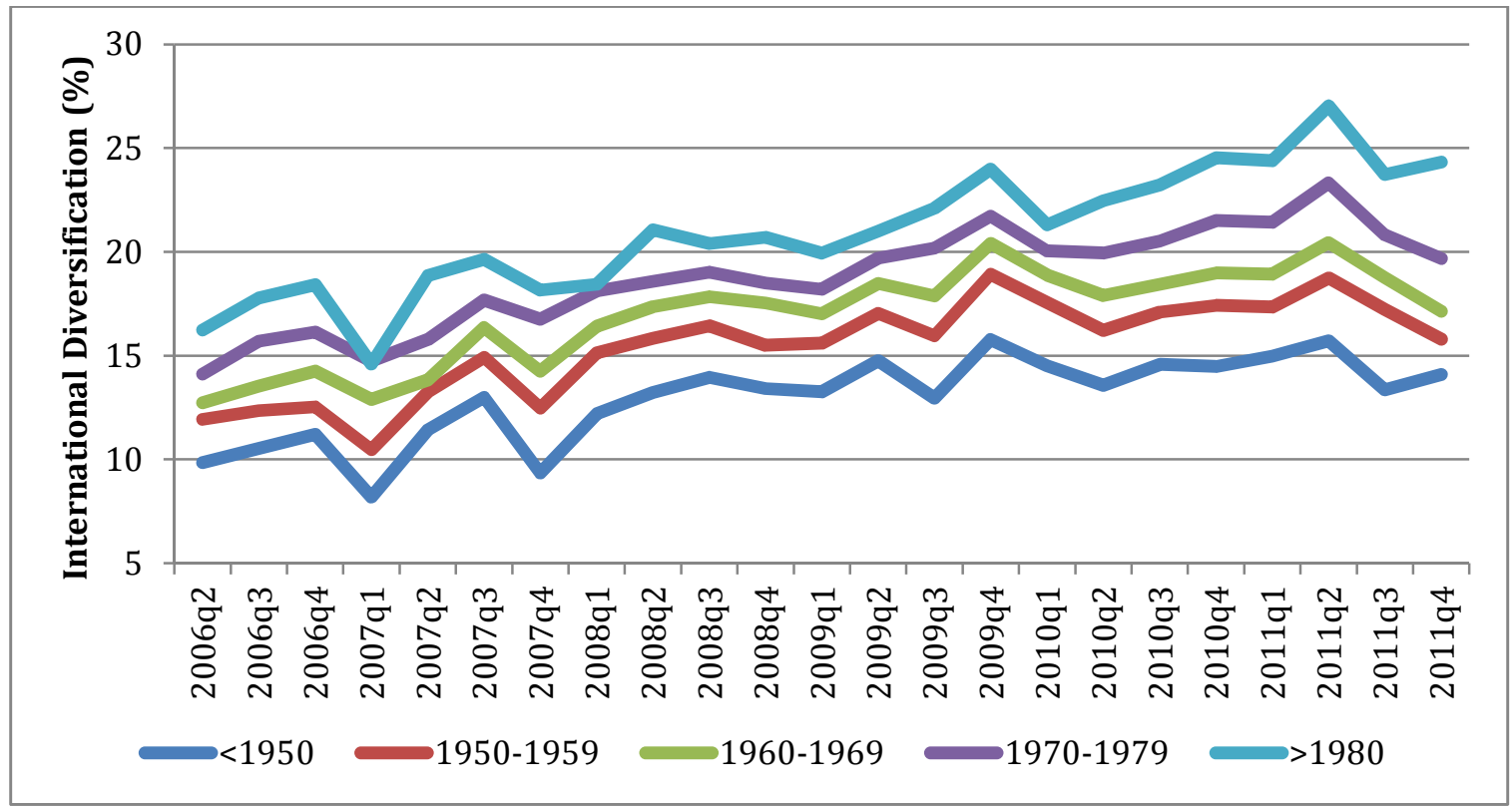


Figure 6

Malmendier and Nagel Experienced Returns

Following Malmendier and Nagel (2011), the experienced returns variable is the weighted average of past returns with weights that depend on an individual's age at time t, how many years ago the return was realized and a parameter lambda that controls for the shape of the weighting function. This paper defines past returns using international stock returns in excess of US stock returns. Panel A shows experienced returns with $\lambda=4.2$, while Panel B shows the variable with $\lambda=1.1$.

Panel $\mathrm{A}-\lambda=4.2$

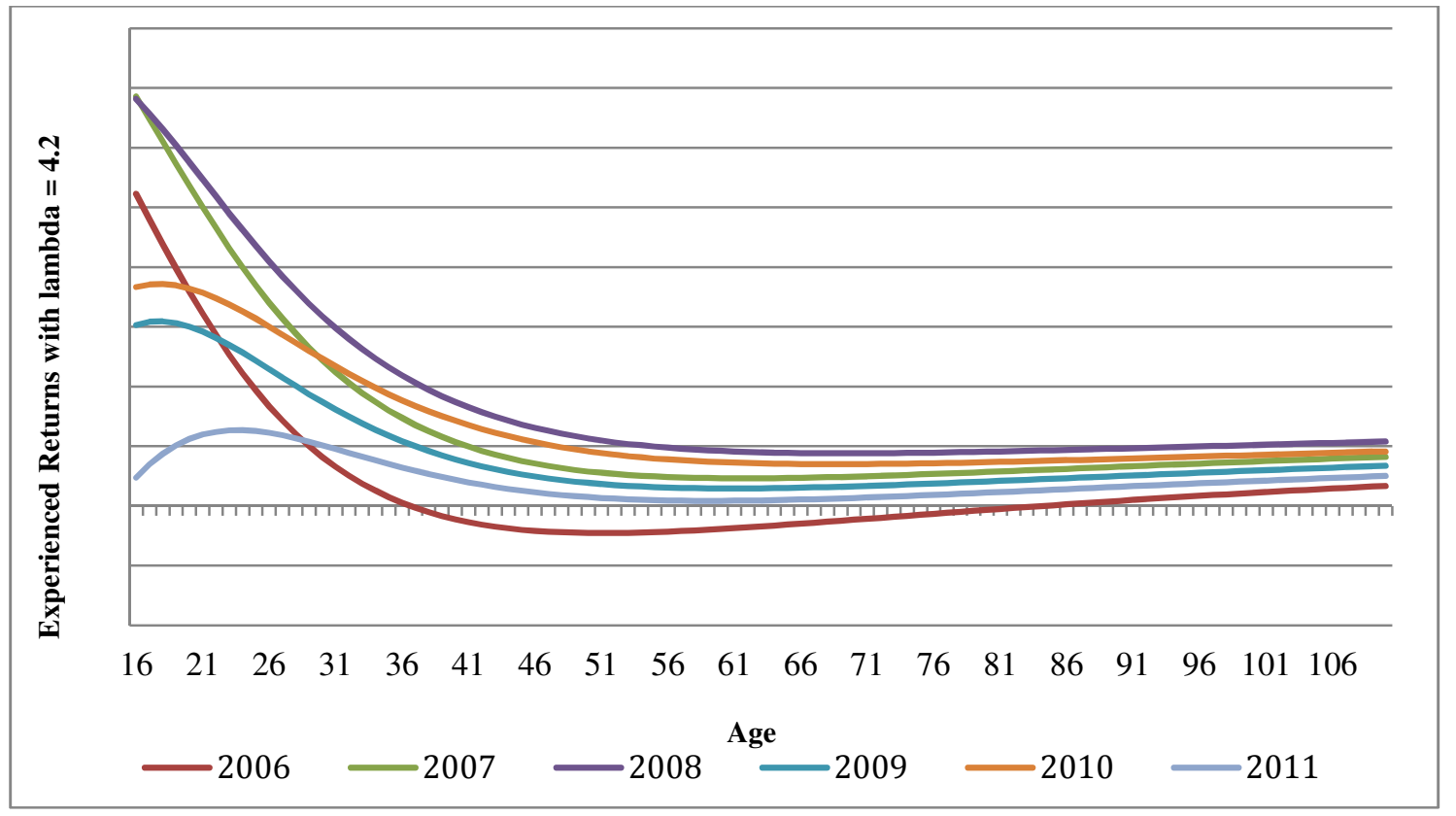

Panel B $-\lambda=1.1$

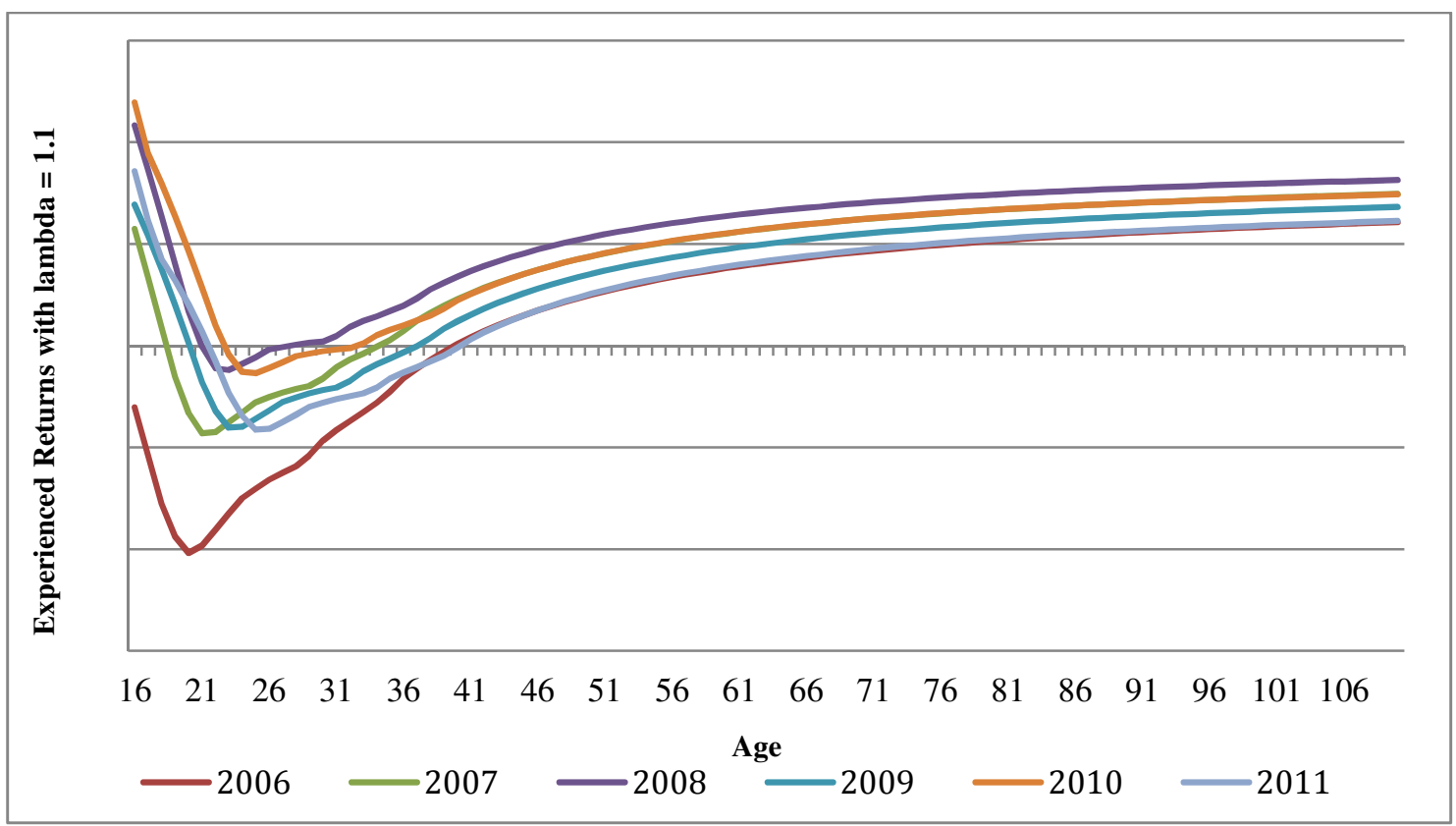




\section{Table 1}

\section{International Under-Diversification in the US}

This table presents statistics for the degree of international diversification, i.e. the international equity allocations as a percent of total stock allocations in individuals' 401(k) portfolios. Firms (states) are ranked according to the average international diversification: diversified firms (state) represent the 5 firms ( 1 state) with the highest average diversification and under-diversified firms represent the bottom 5 firms ( 1 state). This subsample is then split into older people (born in 1960 or earlier) and younger people (born 1980 or later). Finally, within each cohort, individuals are split in three groups (low salary, intermediate salary and high salary). The reported numbers are the average international diversification for each subset.

\begin{tabular}{|c|c|c|c|c|c|}
\hline & $\begin{array}{l}\text { Diversified } \\
\text { Firms }\end{array}$ & $\begin{array}{l}\text { Under-diversified } \\
\text { Firms }\end{array}$ & & $\begin{array}{l}\text { Diversified } \\
\text { State }\end{array}$ & $\begin{array}{l}\text { Under- } \\
\text { diversified State }\end{array}$ \\
\hline Cohort 1960 & & & Cohort 1960 & & \\
\hline Low salary & 33.1 & 3.70 & Low salary & 22.2 & 13.3 \\
\hline $\begin{array}{l}\text { Intermediate } \\
\text { salary }\end{array}$ & 30.7 & 4.86 & $\begin{array}{l}\text { Intermediate } \\
\text { salary }\end{array}$ & 19.7 & 11.2 \\
\hline High salary & 33.7 & 6.76 & High salary & 19.1 & 13.6 \\
\hline Cohort 1980 & & & Cohort 1980 & & \\
\hline Low salary & 39.0 & 10.2 & Low salary & 31.2 & 21.0 \\
\hline $\begin{array}{l}\text { Intermediate } \\
\text { salary }\end{array}$ & 36.3 & 11.8 & $\begin{array}{l}\text { Intermediate } \\
\text { salary }\end{array}$ & 27.7 & 19.1 \\
\hline High salary & 37.4 & 13.7 & High salary & 25.8 & 19.3 \\
\hline
\end{tabular}

Table 2

Summary statistics for stock market participants

This table presents the mean, median, standard deviation, $5^{\text {th }}$ and $95^{\text {th }}$ percentiles and number of observations for the individual level data. The stock market participant sample includes individuals with a positive equity allocation in their 401(k) portfolio. All variables are defined in the Appendix. The sample period is 2006 to 2011.

\begin{tabular}{lcccccc}
\hline Variable & mean & median & sd & p5 & p95 & \# obs \\
\hline International Diversification & 17.8 & 17.2 & 15.9 & 0.0 & 44.4 & $17,426,447$ \\
\% in Target Date Fund & 16.0 & 0.0 & 33.8 & 0.0 & 100.0 & $17,426,447$ \\
International Diversification & 64.4 & 64.8 & 1.5 & 61.4 & 66.0 & $17,426,447$ \\
Benchmark & 1963.7 & 1963 & 11.7 & 1940 & 1983 & $17,426,447$ \\
Cohort & 45.4 & 46.0 & 11.7 & 27.0 & 64.0 & $17,426,447$ \\
Age & 57,962 & 47,624 & 47,531 & 15,265 & 127,216 & $13,373,609$ \\
Annual Salary & 63,832 & 23,387 & 113,594 & 370 & 257,949 & $17,398,644$ \\
Total Account Value & 247,414 & 189,271 & 186,546 & 77,664 & 607,484 & $11,159,024$ \\
House Value & 1.07 & 0.88 & 0.89 & 0.08 & 2.90 & $17,426,447$ \\
MN Experienced Returns & 0.12 & 0.00 & 6.09 & -9.19 & 11.72 & $14,066,672$ \\
Relative Returns & 0.06 & 0.00 & 0.12 & 0.00 & 0.41 & $17,426,447$ \\
Flight to Safety Dummy & & & & & & \\
\hline
\end{tabular}


Table 3

On Time, Cohorts and Age

\section{Panel A - Trends Cohorts and Age Effects}

Panel A reports the results for individual level regressions of international diversification on a quadratic time trend, birth year cohort and age, all controlling for the percent invested in a target date fund and the international diversification benchmark. Columns (2), (5) and (8) control for firm fixed effects, while columns (3), (6) and (9) control for zip code fixed effects. All variables are defined in the Appendix. T-statistics are in brackets. The superscript *** denotes significance at the $1 \%$ level, $* *$ at the $5 \%$ level and $*$ at the $10 \%$ level. Standard errors clustered at the firm level significant at the $5 \%$ level are denoted by bold and underlined t-statistics, while significance at the $10 \%$ level is denoted by underlined t-statistics. The sample period is 2006 to 2011.

\begin{tabular}{|c|c|c|c|c|c|c|c|c|c|}
\hline Variables & $\begin{array}{l}(1) \\
\text { idiv }\end{array}$ & $\begin{array}{l}(2) \\
\text { idiv }\end{array}$ & $\begin{array}{l}(3) \\
\text { idiv } \\
\end{array}$ & $\begin{array}{c}(4) \\
\text { Idiv } \\
\end{array}$ & $\begin{array}{l}(5) \\
\text { idiv } \\
\end{array}$ & $\begin{array}{l}(6) \\
\text { idiv } \\
\end{array}$ & $\begin{array}{l}(7) \\
\text { idiv } \\
\end{array}$ & $\begin{array}{l}(8) \\
\text { idiv } \\
\end{array}$ & $\begin{array}{l}(9) \\
\text { idiv } \\
\end{array}$ \\
\hline$\%$ target date fund & $\begin{array}{c}0.080 * * * \\
{[703]}\end{array}$ & $\begin{array}{c}0.070 * * * \\
{[\mathbf{5 8 6}]}\end{array}$ & $\begin{array}{c}0.078 * * * \\
{[682]}\end{array}$ & $\begin{array}{c}0.068 * * * \\
{[\mathbf{5 9 8}]}\end{array}$ & $\begin{array}{c}0.059 * * * \\
{[491]}\end{array}$ & $\begin{array}{c}0.068 * * * \\
{[\mathbf{5 8 9}]}\end{array}$ & $\begin{array}{c}0.068 * * * \\
{[\mathbf{5 9 7}]}\end{array}$ & $\begin{array}{c}0.059 * * * \\
{[490]}\end{array}$ & $\begin{array}{c}0.068 * * * \\
{[\mathbf{5 8 8}]}\end{array}$ \\
\hline Int'l divers. bmk & $\begin{array}{c}0.20 * * * \\
{[61.7]}\end{array}$ & $\begin{array}{c}0.20 * * * \\
{[\mathbf{6 2 . 0}]}\end{array}$ & $\begin{array}{c}0.19 * * * \\
{[60.0]}\end{array}$ & $\begin{array}{c}0.21 * * * \\
{[66.3]}\end{array}$ & $\begin{array}{c}0.20 * * * \\
{[62.4]}\end{array}$ & $\begin{array}{c}0.20 * * * \\
{[64.2]}\end{array}$ & $\begin{array}{c}0.21 * * * \\
{[65.9]}\end{array}$ & $\begin{array}{c}0.20 * * * \\
{[61.7]}\end{array}$ & $\begin{array}{c}0.20 * * * \\
{[63.7]}\end{array}$ \\
\hline Trend & $\begin{array}{c}0.033 * * * \\
{[7.90]}\end{array}$ & $\begin{array}{c}0.044 * * * \\
{[10.5]}\end{array}$ & $\begin{array}{c}-0.030 * * * \\
{[-7.31]}\end{array}$ & $\begin{array}{c}0.066^{* * *} * \\
{[15.9]}\end{array}$ & $\begin{array}{c}0.056^{* * *} * \\
{[13.5]}\end{array}$ & $\begin{array}{c}-0.0013 \\
{[-0.31]}\end{array}$ & $\begin{array}{c}0.11 * * * \\
{[27.5]}\end{array}$ & $\begin{array}{c}0.10 * * * \\
{[23.9]}\end{array}$ & $\begin{array}{c}0.044 * * * \\
{[10.8]}\end{array}$ \\
\hline Trend $^{2}$ & $\begin{array}{c}0.0077 * * * \\
{[55.3]}\end{array}$ & $\begin{array}{c}0.0044 * * * \\
{[30.7]}\end{array}$ & $\begin{array}{c}0.0093 * * * \\
{[66.8]}\end{array}$ & $\begin{array}{c}0.0056^{* * * *} \\
{[40.4]}\end{array}$ & $\begin{array}{c}0.0033^{* * * *} \\
{[23.5]}\end{array}$ & $\begin{array}{c}0.0074 * * * \\
{[53.3]}\end{array}$ & $\begin{array}{c}0.0054 * * * \\
{[39.0]}\end{array}$ & $\begin{array}{c}0.0032 * * * \\
{[22.5]}\end{array}$ & $\begin{array}{c}0.0072 * * * \\
{[51.9]}\end{array}$ \\
\hline Cohort & & & & $\begin{array}{c}0.17 * * * \\
{[510]}\end{array}$ & $\begin{array}{c}0.16 * * * \\
{[\mathbf{4 8 1}}\end{array}$ & $\begin{array}{c}0.16 * * * \\
{[\mathbf{4 8 0}}\end{array}$ & & & \\
\hline Age & & & & & & & $\begin{array}{c}-0.17 * * * \\
{[-518]}\end{array}$ & $\begin{array}{c}-0.16^{* * *} * \\
{[-488]}\end{array}$ & $\begin{array}{c}-0.16^{* * *} * \\
{[-\mathbf{4 8 8}]}\end{array}$ \\
\hline Constant & $\begin{array}{c}1.15 * * * \\
{[5.86]}\end{array}$ & $\begin{array}{c}2.12 * * * \\
{[11.0]}\end{array}$ & $\begin{array}{c}2.25 * * * \\
{[11.6]}\end{array}$ & $\begin{array}{c}-10.0 * * * \\
{[-51.3]}\end{array}$ & $\begin{array}{c}-7.53 * * * \\
{[-39.1]}\end{array}$ & $\begin{array}{c}-8.44 * * * \\
{[-43.6]}\end{array}$ & $\begin{array}{c}7.47 * * * \\
{[38.3]}\end{array}$ & $\begin{array}{c}9.00 * * * \\
{[46.9]}\end{array}$ & $\begin{array}{c}8.38 * * * \\
{[43.5]}\end{array}$ \\
\hline Observations & $17,426,447$ & $17,426,447$ & $17,412,265$ & $17,426,447$ & $17,426,447$ & $17,412,265$ & $17,426,447$ & $17,426,447$ & $17,412,265$ \\
\hline Adjusted R-squared & 0.039 & 0.119 & 0.073 & 0.054 & 0.131 & 0.086 & 0.054 & 0.131 & 0.086 \\
\hline Firm Fixed Effects & $\mathrm{N}$ & $\mathrm{Y}$ & $\mathrm{N}$ & $\mathrm{N}$ & $\mathrm{Y}$ & $\mathrm{N}$ & $\mathrm{N}$ & $\mathrm{Y}$ & $\mathrm{N}$ \\
\hline $\begin{array}{l}\text { Zip Code Fixed } \\
\text { Effects }\end{array}$ & $\mathrm{N}$ & $\mathrm{N}$ & $\mathrm{Y}$ & $\mathrm{N}$ & $\mathrm{N}$ & $\mathrm{Y}$ & $\mathrm{N}$ & $\mathrm{N}$ & $\mathrm{Y}$ \\
\hline
\end{tabular}




\section{Panel B - Quadratic Function Specifications}

Panel B reports the results for individual level regressions of international diversification on a quadratic time trend, quadratic birth year cohort and quadratic age, controlling for the percent invested in a target date fund and the international diversification benchmark. Columns (2) and (5) control for firm fixed effects, while columns (3) and (6) control for zip code fixed effects. All variables are defined in the Appendix. T-statistics are in brackets. The superscript $* * *$ denotes significance at the $1 \%$ level, ** at the $5 \%$ level and $*$ at the $10 \%$ level. Standard errors clustered at the firm level significant at the 5\% level are denoted by bold and underlined t-statistics, while significance at the $10 \%$ level is denoted by underlined t-statistics. The sample period is 2006 to 2011.

\begin{tabular}{|c|c|c|c|c|c|c|}
\hline Variables & $\begin{array}{l}\text { (1) } \\
\text { idiv }\end{array}$ & $\begin{array}{l}(2) \\
\text { Idiv }\end{array}$ & $\begin{array}{l}(3) \\
\text { idiv } \\
\end{array}$ & $\begin{array}{l}\text { (4) } \\
\text { idiv } \\
\end{array}$ & $\begin{array}{l}(5) \\
\text { idiv } \\
\end{array}$ & $\begin{array}{l}\text { (6) } \\
\text { idiv }\end{array}$ \\
\hline$\%$ target date fund & $\begin{array}{c}0.069 * * * \\
{[601]}\end{array}$ & $\begin{array}{c}0.059 * * * \\
{[490]}\end{array}$ & $\begin{array}{c}0.069 * * * \\
{[\mathbf{5 9 1}]}\end{array}$ & $\begin{array}{c}0.069 * * * \\
{[601]}\end{array}$ & $\begin{array}{c}0.060 * * * \\
{[492]}\end{array}$ & $\begin{array}{c}0.069 * * * \\
{[\mathbf{5 9 1}]}\end{array}$ \\
\hline Int'l divers. benchmark & $\begin{array}{c}0.22 * * * \\
{[66.7]}\end{array}$ & $\begin{array}{c}0.20 * * * \\
{[62.5]}\end{array}$ & $\begin{array}{c}0.21 * * * \\
{[64.5]}\end{array}$ & $\begin{array}{c}0.21 * * * \\
{[66.4]}\end{array}$ & $\begin{array}{c}0.20 * * * \\
{[61.7]}\end{array}$ & $\begin{array}{c}0.20 * * * \\
{[64.2]}\end{array}$ \\
\hline Trend & $\begin{array}{c}0.061 * * * \\
{[14.9]}\end{array}$ & $\begin{array}{c}0.055^{* * *} * \\
{[13.2]}\end{array}$ & $\begin{array}{c}-0.0046 \\
{[-1.12]}\end{array}$ & $\begin{array}{c}0.11 * * * \\
{[26.5]}\end{array}$ & $\begin{array}{c}0.098 * * * \\
{[23.4]}\end{array}$ & $\begin{array}{c}0.041 * * * \\
{[9.91]}\end{array}$ \\
\hline Trend $^{2}$ & $\begin{array}{c}0.0058 * * * \\
{[41.7]}\end{array}$ & $\begin{array}{c}0.0034 * * * \\
{[23.7]}\end{array}$ & $\begin{array}{c}0.0075 * * * \\
{[54.3]}\end{array}$ & $\begin{array}{c}0.0056 * * * \\
{[40.3]}\end{array}$ & $\begin{array}{c}0.0033 * * * \\
{[23.0]}\end{array}$ & $\begin{array}{c}0.0073 * * * \\
{[53.1]}\end{array}$ \\
\hline Cohort & $\begin{array}{c}0.33 * * * \\
{[109]}\end{array}$ & $\begin{array}{c}0.19 * * * \\
{[65.6]}\end{array}$ & $\begin{array}{c}0.28 * * * \\
{[93.0]}\end{array}$ & & & \\
\hline Cohort $^{2}$ & $\begin{array}{c}-0.0013 * * * \\
{[-54.1]}\end{array}$ & $\begin{array}{c}-0.00029 * * * \\
{[-12.5]}\end{array}$ & $\begin{array}{c}-0.00096 * * * \\
{[-40.4]}\end{array}$ & & & \\
\hline Age & & & & $\begin{array}{c}0.00034 \\
{[0.17]}\end{array}$ & $\begin{array}{c}-0.076 * * * \\
{[-38.1]}\end{array}$ & $\begin{array}{c}-0.015 * * * \\
{[-7.25]}\end{array}$ \\
\hline $\mathrm{Age}^{2}$ & & & & $\begin{array}{c}-0.0018 * * * \\
{[\mathbf{- 8 3 . 1}}\end{array}$ & $\begin{array}{c}-0.00089 * * * \\
{[-41.3]}\end{array}$ & $\begin{array}{c}-0.0016 * * * \\
{[-72.1]}\end{array}$ \\
\hline Constant & $\begin{array}{c}-15.0 * * * \\
{[-69.5]}\end{array}$ & $\begin{array}{c}-8.64 * * * \\
{[-40.7]}\end{array}$ & $\begin{array}{c}-12.2 * * * \\
{[-56.8]}\end{array}$ & $\begin{array}{c}3.78 * * * \\
{[18.9]}\end{array}$ & $\begin{array}{c}7.25 * * * \\
{[36.9]}\end{array}$ & $\begin{array}{c}5.17 * * * \\
{[26.2]}\end{array}$ \\
\hline $\begin{array}{l}\text { Observations } \\
\text { Adjusted R-squared } \\
\text { Firm Fixed Effects } \\
\text { Zip Code Fixed Effects }\end{array}$ & $\begin{array}{c}17,426,447 \\
0.054 \\
\mathrm{~N} \\
\mathrm{~N}\end{array}$ & $\begin{array}{c}17,426,447 \\
0.131 \\
\mathrm{Y} \\
\mathrm{N}\end{array}$ & $\begin{array}{c}17,412,265 \\
0.086 \\
\mathrm{~N} \\
\mathrm{Y}\end{array}$ & $\begin{array}{c}17,426,447 \\
0.054 \\
\mathrm{~N} \\
\mathrm{~N}\end{array}$ & $\begin{array}{c}17,426,447 \\
0.131 \\
\mathrm{Y} \\
\mathrm{N}\end{array}$ & $\begin{array}{c}17,412,265 \\
0.086 \\
\mathrm{~N} \\
\mathrm{Y}\end{array}$ \\
\hline
\end{tabular}




\section{Table 4}

\section{The Effect of Return Sensitive Variables}

This table reports the results for individual level regressions of international diversification on a quadratic time trend, birth year cohort and return sensitive variables (experienced returns, international stock returns relative to U.S. stock returns and a flight to safety dummy), all controlling for the percent invested in a target date fund and the international diversification benchmark. The specifications with the MN experienced return and return chasing variables were run using non-linear least squares, leading to an estimate of the parameter lambda measuring how the effect of past returns decay with time. Columns (5) and (8) control for firm fixed effects, while columns (6) and (9) control for zip code fixed effects. All variables are defined in the Appendix. T-statistics are in brackets. The superscript $* * *$ denotes significance at the $1 \%$ level, $* *$ at the $5 \%$ level and $*$ at the $10 \%$ level. Standard errors clustered at the firm level significant at the 5\% level are denoted by bold and underlined t-statistics, while significance at the $10 \%$ level is denoted by underlined tstatistics. The standard errors clustered at the firm level for columns (1) and (2) were calculated using OLS with the optimal $\lambda$. The sample period is 2006 to 2011.

\begin{tabular}{|c|c|c|c|c|c|c|c|c|}
\hline Variables & $\begin{array}{l}(1) \\
\text { idiv }\end{array}$ & $\begin{array}{l}(2) \\
\text { idiv } \\
\end{array}$ & $\begin{array}{l}(3) \\
\text { idiv } \\
\end{array}$ & $\begin{array}{l}(4) \\
\text { idiv } \\
\end{array}$ & $\begin{array}{l}(5) \\
\text { idiv } \\
\end{array}$ & $\begin{array}{l}(6) \\
\text { idiv } \\
\end{array}$ & $\begin{array}{l}(7) \\
\text { idiv } \\
\end{array}$ & $\begin{array}{c}(8) \\
\text { Idiv } \\
\end{array}$ \\
\hline$\%$ target date fund & $\begin{array}{c}0.069 * * * \\
{[599]}\end{array}$ & $\begin{array}{c}0.069 * * * \\
{[599]}\end{array}$ & $\begin{array}{c}0.069 * * * \\
{[539]}\end{array}$ & $\begin{array}{c}0.061 * * * \\
{[454]}\end{array}$ & $\begin{array}{c}0.069 * * * \\
{[534]}\end{array}$ & $\begin{array}{c}0.068 * * * \\
{[597]}\end{array}$ & $\begin{array}{c}0.059 * * * \\
{[492]}\end{array}$ & $\begin{array}{c}0.068 * * * \\
{[587]}\end{array}$ \\
\hline Int'l divers. benchmark & $\begin{array}{c}0.26 * * * \\
{[79.2]}\end{array}$ & $\begin{array}{c}0.19 * * * \\
{[56.8]}\end{array}$ & $\begin{array}{c}0.16^{* * * *} \\
{[38.2]}\end{array}$ & $\begin{array}{c}0.26 * * * \\
{[62.1]}\end{array}$ & $\begin{array}{c}0.18 * * * \\
{[42.4]}\end{array}$ & $\begin{array}{c}0.16^{* * * *} \\
{[38.5]}\end{array}$ & $\begin{array}{c}0.23 * * * \\
{[\mathbf{5 5 . 7}}\end{array}$ & $\begin{array}{c}0.14 * * * \\
{[34.0]}\end{array}$ \\
\hline Trend & $\begin{array}{c}0.16 * * * \\
{[36.9]}\end{array}$ & $\begin{array}{c}0.13 * * * \\
{[29.7]}\end{array}$ & $\begin{array}{c}0.064 * * * \\
{[11.7]}\end{array}$ & $\begin{array}{c}-0.075^{*} * * \\
{[-13.4]}\end{array}$ & $\begin{array}{c}-0.049 * * * \\
{[-9.12]}\end{array}$ & $\begin{array}{c}0.12 * * * \\
{[25.0]}\end{array}$ & $\begin{array}{c}0.026^{* * *} * \\
{[5.19]}\end{array}$ & $\begin{array}{c}0.064 * * * \\
{[13.4]}\end{array}$ \\
\hline Trend $^{2}$ & $\begin{array}{c}0.0013 * * * \\
{[8.97]}\end{array}$ & $\begin{array}{c}0.0039 * * * \\
{[26.96]}\end{array}$ & $\begin{array}{c}0.0058 * * * \\
{[32.5]}\end{array}$ & $\begin{array}{c}0.0067 * * * \\
{[36.7]}\end{array}$ & $\begin{array}{c}0.0086 * * * \\
{[48.6]}\end{array}$ & $\begin{array}{c}0.0039 * * * \\
{[24.3]}\end{array}$ & $\begin{array}{c}0.0043 * * * \\
{[26.1]}\end{array}$ & $\begin{array}{c}0.0053 * * * \\
{[33.4]}\end{array}$ \\
\hline Cohort & $\begin{array}{c}0.19 * * * \\
{[365}\end{array}$ & $\begin{array}{c}0.17 * * * \\
{[442]}\end{array}$ & $\begin{array}{c}0.17 * * * \\
{[456]}\end{array}$ & $\begin{array}{c}0.15 * * * \\
{[422]}\end{array}$ & $\begin{array}{c}0.16^{* * *} \\
{[426]}\end{array}$ & $\begin{array}{c}0.17 * * * \\
{[\mathbf{5 1 0}]}\end{array}$ & $\begin{array}{c}0.16 * * * \\
{[481]}\end{array}$ & $\begin{array}{c}0.16 * * * \\
{[480]}\end{array}$ \\
\hline MN Experienced Ret & $\begin{array}{c}-0.53 * * * \\
{[-73.0]}\end{array}$ & & & & & & & \\
\hline Return Chasing & & $\begin{array}{c}0.16^{* * * *} \\
{[37.5]}\end{array}$ & & & & & & \\
\hline Relative returns & & & $\begin{array}{c}-0.0045 * * * \\
{[-5.53]}\end{array}$ & $\begin{array}{c}-0.0097 * * * \\
{[-12.2]}\end{array}$ & $\begin{array}{c}-0.0053 * * * \\
{[-6.72]}\end{array}$ & & & \\
\hline Flight to Safety & & & & & & $\begin{array}{c}-0.90 * * * \\
{[-21.9]}\end{array}$ & $\begin{array}{c}0.49 * * * \\
{[11.6]}\end{array}$ & $\begin{array}{c}-1.07 * * * \\
{[-26.3]}\end{array}$ \\
\hline$\lambda$ & $\begin{array}{c}4.13 * * * \\
{[104]}\end{array}$ & $\begin{array}{l}1.05 * * * \\
{[52.29]}\end{array}$ & & & & & & \\
\hline Constant & $\begin{array}{c}-14.5 * * * \\
{[-71.1]}\end{array}$ & $\begin{array}{c}-10.8 * * * \\
{[-54.8]}\end{array}$ & $\begin{array}{c}-6.85 * * * \\
{[-26.4]}\end{array}$ & $\begin{array}{c}-10.5 * * * \\
{[-40.8]}\end{array}$ & $\begin{array}{c}-6.39 * * * \\
{[-24.9]}\end{array}$ & $\begin{array}{c}-6.78 * * * \\
{[-27.5]}\end{array}$ & $\begin{array}{c}-9.27 * * * \\
{[-38.0]}\end{array}$ & $\begin{array}{c}-4.56 * * * \\
{[-18.8]}\end{array}$ \\
\hline Observations & $17,426,447$ & $17,426,477$ & $14,066,672$ & $14,066,672$ & $14,055,507$ & $17,426,447$ & $17,426,447$ & $17,412,265$ \\
\hline Adjusted R-squared & 0.054 & 0.054 & 0.051 & 0.127 & 0.086 & 0.054 & 0.131 & 0.086 \\
\hline Firm Fixed Effects & $\mathrm{N}$ & $\mathrm{N}$ & $\mathrm{N}$ & $\mathrm{Y}$ & $\mathrm{N}$ & $\mathrm{N}$ & $\mathrm{Y}$ & $\mathrm{N}$ \\
\hline Zip Code Fixed Effects & $\mathrm{N}$ & $\mathrm{N}$ & $\mathrm{N}$ & $\mathrm{N}$ & $\mathrm{Y}$ & $\mathrm{N}$ & $\mathrm{N}$ & $\mathrm{Y}$ \\
\hline
\end{tabular}




\section{Table 5}

\section{Income, Wealth and International Diversification}

This table reports the results for individual level regressions of international diversification on a quadratic time trend, birth year cohort and wealth variables (annual salary, 401(k) account value and the house value corresponding to the individual's zip code), all controlling for the percent invested in a target date fund and the international diversification benchmark. House values are either from Zillow (columns (1) and (2), or from the Census (Columns (4) and (5)). Columns (2) and (5) control for firm fixed effects, while column (3) controls for zip code fixed effects. All variables are defined in the Appendix. T-statistics are in brackets. The superscript *** denotes significance at the $1 \%$ level, $* *$ at the $5 \%$ level and $*$ at the $10 \%$ level. Standard errors clustered at the firm level significant at the $5 \%$ level are denoted by bold and underlined t-statistics, while significance at the $10 \%$ level is denoted by underlined t-statistics. The sample period is 2006 to 2011.

\begin{tabular}{|c|c|c|c|c|c|}
\hline Variables & $\begin{array}{l}\text { (1) } \\
\text { idiv } \\
\end{array}$ & $\begin{array}{l}\text { (2) } \\
\text { idiv } \\
\end{array}$ & $\begin{array}{l}\text { (3) } \\
\text { Idiv }\end{array}$ & $\begin{array}{c}(4) \\
\text { Idiv }\end{array}$ & $\begin{array}{l}(5) \\
\text { Idiv } \\
\end{array}$ \\
\hline$\%$ target date fund & $\begin{array}{c}0.066 * * * \\
{[394]}\end{array}$ & $\begin{array}{c}0.056 * * * \\
{[314]}\end{array}$ & $\begin{array}{c}0.065 * * * \\
{[494]}\end{array}$ & $\begin{array}{c}0.069 * * * \\
{[\mathbf{5 2 5}]}\end{array}$ & $\begin{array}{c}0.057 * * * \\
{[408]}\end{array}$ \\
\hline Int'l diversification benchmark & $\begin{array}{c}0.36 * * * \\
{[77.6]}\end{array}$ & $\begin{array}{c}0.31 * * * \\
{[67.5]}\end{array}$ & $\begin{array}{c}0.33 * * * \\
{[\mathbf{9 0 . 4}]}\end{array}$ & $\begin{array}{c}0.34 * * * \\
{[91.1]}\end{array}$ & $\begin{array}{c}0.28 * * * \\
{[77.4]}\end{array}$ \\
\hline Trend & $\begin{array}{c}-0.054 * * * \\
{[-9.35]}\end{array}$ & $\begin{array}{c}0.063 * * * \\
{[10.6]}\end{array}$ & $\begin{array}{c}-0.10 * * * \\
{[-22.9]}\end{array}$ & $\begin{array}{c}-0.081 * * * \\
{[-17.4]}\end{array}$ & $\begin{array}{c}0.019 * * * \\
{[4.03]}\end{array}$ \\
\hline Trend $^{2}$ & $\begin{array}{c}0.0084 * * * \\
{[42.8]}\end{array}$ & $\begin{array}{c}0.0028^{* * * *} \\
{[14.0]}\end{array}$ & $\begin{array}{c}0.0099 * * * \\
{[64.4]}\end{array}$ & $\begin{array}{c}0.0095 * * * \\
{[60.7]}\end{array}$ & $\begin{array}{c}0.0043 * * * \\
{[26.6]}\end{array}$ \\
\hline Cohort & $\begin{array}{c}0.14 * * * \\
{[276]}\end{array}$ & $\begin{array}{c}0.14 * * * \\
{[276]}\end{array}$ & $\begin{array}{c}0.14 * * * \\
{[328]}\end{array}$ & $\begin{array}{c}0.15 * * * \\
{[352]}\end{array}$ & $\begin{array}{c}0.14 * * * \\
{[349]}\end{array}$ \\
\hline $\ln$ (annual salary) & $\begin{array}{c}-2.73 * * * \\
{[-83.5]}\end{array}$ & $\begin{array}{c}-2.51 * * * \\
{[-78.5]}\end{array}$ & $\begin{array}{c}-1.93 * * * \\
{[-78.9]}\end{array}$ & $\begin{array}{c}-2.50 * * * \\
{[-101]}\end{array}$ & $\begin{array}{c}-2.32 * * * \\
{[-96.7]}\end{array}$ \\
\hline $\ln (\text { annual salary })^{2}$ & $\begin{array}{c}0.20 * * * \\
{[112]}\end{array}$ & $\begin{array}{c}0.19 * * * \\
{[109]}\end{array}$ & $\begin{array}{c}0.15^{* * * *} \\
{[114]}\end{array}$ & $\begin{array}{c}0.19 * * * \\
{[\mathbf{1 4 0}]}\end{array}$ & $\begin{array}{c}0.18 * * * \\
{[\mathbf{1 3 8}]}\end{array}$ \\
\hline $\ln ($ account value $)$ & $\begin{array}{c}0.80 * * * \\
{[\mathbf{5 0 . 9}}\end{array}$ & $\begin{array}{c}0.47 * * * \\
{[30.6]}\end{array}$ & $\begin{array}{c}0.76 * * * \\
{[61.7]}\end{array}$ & $\begin{array}{c}0.74 * * * \\
{[59.2]}\end{array}$ & $\begin{array}{c}0.41 * * * \\
{[33.9]}\end{array}$ \\
\hline $\ln (\text { account value })^{2}$ & $\begin{array}{c}-0.051 * * * \\
{[-57.1]}\end{array}$ & $\begin{array}{c}-0.032 * * * \\
{[-36.9]}\end{array}$ & $\begin{array}{c}-0.049 * * * \\
{[-70.3]}\end{array}$ & $\begin{array}{c}-0.046 * * * \\
{[-65.6]}\end{array}$ & $\begin{array}{c}-0.029 * * * \\
{[-42.8]}\end{array}$ \\
\hline $\ln$ (house value Zillow) & $\begin{array}{c}0.63 * * * \\
{[71.9]}\end{array}$ & $\begin{array}{c}0.57 * * * \\
{[57.2]}\end{array}$ & & & \\
\hline $\ln$ (house value census) & & & & $\begin{array}{c}0.96^{* * * *} \\
{[132]}\end{array}$ & $\begin{array}{c}0.82 * * * \\
{[\mathbf{9 8 . 7}}\end{array}$ \\
\hline Constant & $\begin{array}{c}-20.5 * * * \\
{[-58.8]}\end{array}$ & $\begin{array}{c}-16.7 * * * \\
{[-48.1]}\end{array}$ & $\begin{array}{c}-13.2 * * * \\
{[-51.9]}\end{array}$ & $\begin{array}{c}-24.3 * * * \\
{[-88.7]}\end{array}$ & $\begin{array}{c}-18.6 * * * \\
{[-67.9]}\end{array}$ \\
\hline $\begin{array}{l}\text { Observations } \\
\text { Adjusted R-squared } \\
\text { Firm Fixed Effects } \\
\text { Zip Code Fixed Effects } \\
\end{array}$ & $\begin{array}{c}8,553,859 \\
0.047 \\
\mathrm{~N} \\
\mathrm{~N} \\
\end{array}$ & $\begin{array}{c}8,553,859 \\
0.118 \\
\mathrm{Y} \\
\mathrm{N} \\
\end{array}$ & $\begin{array}{c}13,338,002 \\
0.086 \\
\mathrm{~N} \\
\mathrm{Y} \\
\end{array}$ & $\begin{array}{c}13,149,891 \\
0.053 \\
\mathrm{~N} \\
\mathrm{~N} \\
\end{array}$ & $\begin{array}{c}13,149,891 \\
0.130 \\
\mathrm{Y} \\
\mathrm{N} \\
\end{array}$ \\
\hline
\end{tabular}


Table 6

The Geography of International Diversification

\section{Panel A - Summary statistics}

Panel A presents the mean, median, standard deviation, $5^{\text {th }}$ and $95^{\text {th }}$ percentiles and number of observations for the zip code level data. All variables are defined in the Appendix.

\begin{tabular}{|c|c|c|c|c|c|c|}
\hline Variables & mean & median & $\mathrm{sd}$ & $\mathrm{p} 5$ & p95 & \# obs \\
\hline Bachelor's Degree or Higher & 21.8 & 17.4 & 16.0 & 3.1 & 55.4 & 32,746 \\
\hline Less than College Degree & 63.4 & 65.6 & 14.2 & 36.7 & 81.9 & 32,746 \\
\hline College Degree & 14.0 & 11.9 & 9.8 & 0.0 & 32.5 & 32,746 \\
\hline Advanced Degree & 7.8 & 5.4 & 8.4 & 0.0 & 24.0 & 32,746 \\
\hline Financial Literacy & 2.9 & 2.9 & 0.1 & 2.7 & 3.1 & 42,107 \\
\hline Foreign Born Population & 5.8 & 2.2 & 9.2 & 0.0 & 26.0 & 32,751 \\
\hline Foreign Born Population - Latin America & 2.9 & 0.4 & 6.6 & 0.0 & 15.4 & 32,751 \\
\hline Foreign Born Population - Europe & 1.0 & 0.3 & 2.1 & 0.0 & 4.0 & 32,751 \\
\hline Foreign Born Population - Asia & 1.5 & 0.2 & 3.8 & 0.0 & 6.9 & 32,751 \\
\hline Foreign Born Population - Other & 0.5 & 0.0 & 1.2 & 0.0 & 2.0 & 32,751 \\
\hline Distance to International Cities & 13,070 & 12,801 & 790 & 12,272 & 14,565 & 41,631 \\
\hline Distance to Tokyo & 6,323 & 6,515 & 624 & 5,121 & 6,987 & 41,631 \\
\hline Distance to London & 4,210 & 4,143 & 596 & 3,350 & 5,322 & 41,631 \\
\hline Distance to Mexico City & 1,647 & 1,655 & 451 & 924 & 2,273 & 41,631 \\
\hline Distance to Toronto & 890 & 705 & 647 & 223 & 2,165 & 41,631 \\
\hline Rural & 2.0 & 1.0 & 1.2 & 1.0 & 4.0 & 41,982 \\
\hline Long Distance Minutes & 47 & 46 & 7 & 42 & 57 & 42,107 \\
\hline State Exports/GDP & 7.2 & 6.6 & 3.2 & 3.0 & 14.4 & 42,107 \\
\hline State Openness & 20.4 & 17.8 & 9.2 & 8.7 & 38.6 & 42,107 \\
\hline GDP per capita & 41,861 & 40,451 & 10,525 & 31,715 & 51,714 & 42,107 \\
\hline GDP Growth 2000-2005 & 11.4 & 11.3 & 5.4 & 3.5 & 24.0 & 42,107 \\
\hline GDP Growth 2006-2011 & 2.9 & 2.6 & 6.2 & -7.1 & 13.7 & 42,107 \\
\hline House Value - Zillow & 212,646 & 160,583 & 175,942 & 67,808 & 518,252 & 8,868 \\
\hline House Value - Census & 172,967 & 125,900 & 145,372 & 52,100 & 454,800 & 31,921 \\
\hline
\end{tabular}




\section{Panel B - International Diversification Results}

The regressions in this table examine the zip code fixed effects extracted from an individual level regression of international diversification on the percent invested in a target date fund, the international diversification benchmark, a quadratic time trend, birth year cohort, quadratic annual salary and quadratic account value. Columns (2) and (4) include house values from the Zillow sample; Column (5) replicates Column (4) including house values from the 2010 Census, Columns (1), (3) and (6) do not include house values and are based on all the zip codes in our sample. All variables are defined in the Appendix. T-statistics are in brackets. The superscript $* * *$ denotes significance at the $1 \%$ level, ** at the $5 \%$ level and $*$ at the $10 \%$ level.

\begin{tabular}{|c|c|c|c|c|c|c|}
\hline Variables & $\begin{array}{c}(1) \\
\text { Zip Code FE }\end{array}$ & $\begin{array}{c}(2) \\
\text { Zip Code FE }\end{array}$ & $\begin{array}{c}(3) \\
\text { Zip Code FE }\end{array}$ & $\begin{array}{c}(4) \\
\text { Zip Code FE }\end{array}$ & $\begin{array}{c}(5) \\
\text { Zip Code FE }\end{array}$ & $\begin{array}{c}(6) \\
\text { Zip Code FE }\end{array}$ \\
\hline Bachelor's or Higher & $\begin{array}{c}0.048 * * * \\
{[16.0]}\end{array}$ & $\begin{array}{c}0.050 * * * \\
{[15.2]}\end{array}$ & & & & \\
\hline High School Degree & & & $\begin{array}{c}0.037 * * * \\
{[6.27]}\end{array}$ & $\begin{array}{c}0.064 * * * \\
{[7.98]}\end{array}$ & $\begin{array}{c}0.042 * * * \\
{[6.65]}\end{array}$ & $\begin{array}{c}0.037 * * * \\
{[6.26]}\end{array}$ \\
\hline Bachelor's Degree & & & $\begin{array}{c}0.068 * * * \\
{[9.61]}\end{array}$ & $\begin{array}{c}0.091 * * * \\
{[10.4]}\end{array}$ & $\begin{array}{c}0.071 * * * \\
{[8.51]}\end{array}$ & $\begin{array}{c}0.067 * * * \\
{[9.47]}\end{array}$ \\
\hline Advanced Degree & & & $\begin{array}{c}0.067 * * * \\
{[7.58]}\end{array}$ & $\begin{array}{c}0.10 * * * \\
{[9.27]}\end{array}$ & $\begin{array}{c}0.081 * * * \\
{[7.82]}\end{array}$ & $\begin{array}{c}0.068 * * * \\
{[7.66]}\end{array}$ \\
\hline Financial Literacy & $\begin{array}{c}3.50 * * * \\
{[9.71]}\end{array}$ & $\begin{array}{c}0.36 \\
{[1.00]}\end{array}$ & $\begin{array}{c}2.05 * * * \\
{[4.14]}\end{array}$ & $\begin{array}{c}0.82 \\
{[1.61]}\end{array}$ & $\begin{array}{c}1.81 * * * \\
{[3.64]}\end{array}$ & $\begin{array}{c}2.00 * * * \\
{[3.96]}\end{array}$ \\
\hline Foreign Born Population & $\begin{array}{c}0.031 * * * \\
{[5.78]}\end{array}$ & $\begin{array}{c}0.028 * * * \\
{[7.05]}\end{array}$ & & & & \\
\hline Foreign Born - LatAm & & & $\begin{array}{c}0.039 * * * \\
{[4.99]}\end{array}$ & $\begin{array}{c}0.071 * * * \\
{[10.3]}\end{array}$ & $\begin{array}{c}0.049 * * * \\
{[5.96]}\end{array}$ & $\begin{array}{c}0.039 * * * \\
{[4.96]}\end{array}$ \\
\hline Foreign Born - Europe & & & $\begin{array}{c}0.11 * * * \\
{[4.20]}\end{array}$ & $\begin{array}{c}0.15^{* * * *} \\
{[6.63]}\end{array}$ & $\begin{array}{c}0.11 * * * \\
{[3.90]}\end{array}$ & $\begin{array}{c}0.11 * * * \\
{[4.14]}\end{array}$ \\
\hline Foreign Born - Asia & & & $\begin{array}{c}0.049 * * * \\
{[3.74]}\end{array}$ & $\begin{array}{c}0.018 * * \\
{[2.10]}\end{array}$ & $\begin{array}{c}0.027 * * \\
{[1.98]}\end{array}$ & $\begin{array}{c}0.046 * * * \\
{[3.53]}\end{array}$ \\
\hline Foreign Born - Other & & & $\begin{array}{c}0.057 \\
{[1.35]}\end{array}$ & $\begin{array}{c}-0.0045 \\
{[-0.12]}\end{array}$ & $\begin{array}{c}0.064 \\
{[1.51]}\end{array}$ & $\begin{array}{c}0.062 \\
{[1.47]}\end{array}$ \\
\hline Distance to International Cities & $\begin{array}{c}-1.19 \\
{[-1.24]}\end{array}$ & $\begin{array}{c}-0.015 \\
{[-0.020]}\end{array}$ & & & & \\
\hline Distance to Tokyo & & & $\begin{array}{c}-4.34 * * * \\
{[-3.21]}\end{array}$ & $\begin{array}{l}2.36 * * \\
{[2.07]}\end{array}$ & $\begin{array}{c}-4.94 * * * \\
{[-3.60]}\end{array}$ & $\begin{array}{c}-4.81 * * * \\
{[-3.56]}\end{array}$ \\
\hline Distance to London & & & $\begin{array}{c}-4.54 * * \\
{[-2.42]}\end{array}$ & $\begin{array}{c}10.3 * * * \\
{[6.05]}\end{array}$ & $\begin{array}{l}-4.92 * * * \\
{[-2.60]}\end{array}$ & $\begin{array}{c}-5.94 * * * \\
{[-3.24]}\end{array}$ \\
\hline Distance to Mexico City & & & $\begin{array}{c}-1.29 * * * \\
{[-2.74]}\end{array}$ & $\begin{array}{c}2.40 * * * \\
{[6.30]}\end{array}$ & $\begin{array}{l}-1.39 * * * \\
{[-2.88]}\end{array}$ & $\begin{array}{c}-1.61 * * * \\
{[-3.49]}\end{array}$ \\
\hline Distance to Toronto & & & $\begin{array}{c}0.44 \\
{[1.34]}\end{array}$ & $\begin{array}{c}-1.76 * * * \\
{[-5.43]}\end{array}$ & $\begin{array}{c}0.48 \\
{[1.43]}\end{array}$ & $\begin{array}{l}0.70 * * \\
{[2.16]}\end{array}$ \\
\hline
\end{tabular}


Urban

Large Rural

Small Rural

Long Distance Minutes

State Exports/GDP

State Openness

GDP per capita

GDP Growth 2000-2005

GDP Growth 2006-2011

$\ln$ (House Value Zillow)

$\ln$ (House Value Census)

Constant

Observations

R-squared

$\begin{array}{ccc}-0.31 * * * & -0.97 * * * & -0.33 * * * \\ {[-2.60]} & {[-4.00]} & {[-2.69]} \\ -0.40 * * * & -1.26 * * * & -0.40 * * * \\ {[-2.73]} & {[-4.63]} & {[-2.70]} \\ -0.090 & -1.16 * * * & -0.053 \\ {[-0.57]} & {[-3.78]} & {[-0.33]} \\ -0.036 * * * & 0.029 * * * & -0.015 \\ {[-3.07]} & {[2.81]} & {[-1.11]} \\ 0.091 * * * & 0.087 * * * & 0.082 * * * \\ {[5.71]} & {[6.02]} & {[4.84]}\end{array}$

\section{$-0.000017 * *$}

[-2.33]

0.0045

[0.43]

0.0075

[0.97]

$-0.000030 * * *$
$[-4.74]$
0.010
$[1.09]$
$0.033 * * *$
$[4.31]$
0.041
$[0.39]$

$-0.000031 * * *$

[-3.84]

0.0054

[0.48]

0.0070

[0.84]

[0.39]

$-16.7 * * *$

[-12.5]

[-15.9]

28,547

0.018

$[-3.36]$

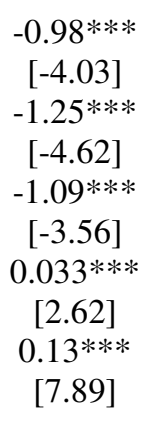

$-0.37 * * *$

[-2.96]

$-0.40 * * *$

[-2.70]

$-0.075$

[-0.48]

$-0.015$

[-1.07]

$0.082 * * *$

[4.84]
$-0.000034 * * *$
[-4.47]
$0.032 * * *$
[3.00]
$0.055^{* * * *}$
[6.80]
$-0.13$
[-1.21]

$-0.000034 * * *$

[-4.25]

0.0063

[0.56]

0.0065

[0.77]

$-0.030$

[-0.25]

$-10.8 * * *$

[-2.81]

$-9.85 * * *$

$-35.4 * * *$

28,156

0.021

$-0.31 * * *$

[-2.58]

$-0.40 * * *$

[-2.72]

$-0.048$

[-0.30]

$-0.023 *$

[-1.67]

$0.020 * * *$

[3.32]

$-0.000032 * * *$

[-4.00]

0.0044

[0.39]

0.012

[1.44]

8,773

0.091 
Table 7

\section{The Firm and International Diversification}

\section{Panel A - Summary statistics on firm characteristics}

Panel A presents the mean, median, standard deviation, $5^{\text {th }}$ and $95^{\text {th }}$ percentiles and number of observations for the firm level data. For the private, foreign headquarter, foreign subsidiary dummies and the $\%$ of foreign subsidiaries variable, we substitute the median with the average of the $49^{\text {th }}$ $51^{\text {st }}$ percentiles, the $5^{\text {th }}$ percentile with the average of the $4^{\text {th }}-6^{\text {th }}$ percentiles, and the $95^{\text {th }}$ percentile with the average of the $94^{\text {th }}-96^{\text {th }}$ percentiles. All variables are defined in the Appendix.

\begin{tabular}{|c|c|c|c|c|c|c|}
\hline Variables & mean & median & sd & p5 & p95 & \# obs \\
\hline Private Dummy & 0.62 & 1.00 & 0.48 & 0.00 & 1.00 & 290 \\
\hline Foreign Headquarter Dummy & 0.16 & 0.00 & 0.37 & 0.00 & 1.00 & 290 \\
\hline Foreign Subsidiary Dummy & 0.56 & 1.00 & 0.50 & 0.00 & 1.00 & 289 \\
\hline Foreign Subsidiaries (\%) & 28.6 & 10.5 & 33.5 & 0.0 & 87.3 & 289 \\
\hline Industry Openness & 24.0 & 0.0 & 35.9 & 0.0 & 118 & 264 \\
\hline Firm Age & 69 & 65 & 45 & 9 & 147 & 268 \\
\hline \# Employees & 18,623 & 4,650 & 48,093 & 220 & 70,000 & 265 \\
\hline Assets (USD mn) & 38,693 & 3,674 & 200,300 & 48 & 79,980 & 156 \\
\hline Leverage $(\%)$ & 30.6 & 27.9 & 20.6 & 4.9 & 65.3 & 126 \\
\hline Sales/Assets (\%) & 106 & 78.3 & 120 & 8.05 & 293 & 152 \\
\hline Profitability $(\%)$ & 2.84 & 2.74 & 9.67 & -14.30 & 14.7 & 156 \\
\hline Investment Intensity (\%) & 4.18 & 3.53 & 3.28 & 0.12 & 10.6 & 125 \\
\hline Plan Assets - Total per firm (USD mn) & 871 & 250 & 2298 & 20 & 3439 & 253 \\
\hline Plan Assets - Average per plan within firm (USD mn) & 602 & 202 & 1218 & 20 & 2695 & 253 \\
\hline
\end{tabular}




\section{Panel B - Firm characteristics and diversification}

The regressions in this table examine the firm fixed effects extracted from an individual level regression of international diversification on the percent invested in a target dated fund, the international diversification benchmark, a quadratic time trend, birth year cohort, quadratic annual salary, quadratic account value, and the house value corresponding to the individual's zip code. All variables are defined in the Appendix. Tstatistics are in brackets. The superscript $* * *$ denotes significance at the $1 \%$ level, $* *$ at the $5 \%$ level and * at the $10 \%$ level.

\begin{tabular}{|c|c|c|c|c|c|c|c|}
\hline Variables & $\begin{array}{c}(1) \\
\text { Firm FE }\end{array}$ & $\begin{array}{c}(2) \\
\text { Firm FE } \\
\end{array}$ & $\begin{array}{c}(3) \\
\text { Firm FE } \\
\end{array}$ & $\begin{array}{c}(4) \\
\text { Firm FE } \\
\end{array}$ & $\begin{array}{c}5) \\
\text { Firm FE } \\
\end{array}$ & $\begin{array}{c}(6) \\
\text { Firm FE }\end{array}$ & $\begin{array}{c}(7) \\
\text { Firm FE }\end{array}$ \\
\hline $\ln ($ Firm Age) & & & $\begin{array}{c}0.13 \\
{[0.23]}\end{array}$ & $\begin{array}{c}0.36 \\
{[0.60]}\end{array}$ & $\begin{array}{c}0.33 \\
{[0.56]}\end{array}$ & $\begin{array}{c}0.37 \\
{[0.62]}\end{array}$ & $\begin{array}{c}0.25 \\
{[0.42]}\end{array}$ \\
\hline $\ln$ (Total Employees) & & & $\begin{array}{c}0.073 \\
{[0.13]}\end{array}$ & $\begin{array}{c}0.21 \\
{[0.37]}\end{array}$ & $\begin{array}{c}0.12 \\
{[0.21]}\end{array}$ & $\begin{array}{c}0.39 \\
{[0.62]}\end{array}$ & $\begin{array}{c}0.20 \\
{[0.33]}\end{array}$ \\
\hline $\ln$ (Assets) & & & $\begin{array}{c}-0.038 \\
{[-0.076]}\end{array}$ & $\begin{array}{c}0.0037 \\
{[0.0069]}\end{array}$ & $\begin{array}{c}0.0014 \\
{[0.0027]}\end{array}$ & $\begin{array}{c}0.72 \\
{[1.20]}\end{array}$ & $\begin{array}{c}0.60 \\
{[1.00]}\end{array}$ \\
\hline Leverage & & & $\begin{array}{c}-0.0042 \\
{[-0.16]}\end{array}$ & $\begin{array}{c}-0.0077 \\
{[-0.29]}\end{array}$ & $\begin{array}{c}-0.0049 \\
{[-0.19]}\end{array}$ & $\begin{array}{c}0.0046 \\
{[0.14]}\end{array}$ & $\begin{array}{c}0.0053 \\
{[0.16]}\end{array}$ \\
\hline Sales/Assets & & & $\begin{array}{c}0.0026 \\
{[0.19]}\end{array}$ & $\begin{array}{c}-0.00098 \\
{[-0.072]}\end{array}$ & $\begin{array}{c}-0.0021 \\
{[-0.15]}\end{array}$ & $\begin{array}{c}0.0072 \\
{[0.51]}\end{array}$ & $\begin{array}{c}0.0053 \\
{[0.38]}\end{array}$ \\
\hline Profitability & & & $\begin{array}{l}-0.15^{* *} \\
{[-2.12]}\end{array}$ & $\begin{array}{l}-0.16^{* *} \\
{[-2.19]}\end{array}$ & $\begin{array}{l}-0.15^{* *} \\
{[-2.08]}\end{array}$ & $\begin{array}{l}-0.13^{*} \\
{[-1.78]}\end{array}$ & $\begin{array}{c}-0.13^{*} \\
{[-1.73]}\end{array}$ \\
\hline Investment Intensity & & & $\begin{array}{l}-0.100 \\
{[-0.66]}\end{array}$ & $\begin{array}{l}-0.034 \\
{[-0.21]}\end{array}$ & $\begin{array}{l}0.0036 \\
{[0.023]}\end{array}$ & $\begin{array}{l}-0.063 \\
{[-0.38]}\end{array}$ & $\begin{array}{l}-0.040 \\
{[-0.24]}\end{array}$ \\
\hline Industry Openness & $\begin{array}{c}0.0040 \\
{[0.43]}\end{array}$ & $\begin{array}{c}0.0041 \\
{[0.46]}\end{array}$ & & $\begin{array}{c}0.00043 \\
{[0.031]}\end{array}$ & $\begin{array}{c}-0.00056 \\
{[-0.043]}\end{array}$ & $\begin{array}{c}0.0041 \\
{[0.29]}\end{array}$ & $\begin{array}{c}0.0019 \\
{[0.14]}\end{array}$ \\
\hline Private & $\begin{array}{c}3.17^{* * *} \\
{[4.67]}\end{array}$ & $\begin{array}{c}3.01^{* * *} \\
{[4.24]}\end{array}$ & & $\begin{array}{l}3.54^{* *} \\
{[2.05]}\end{array}$ & $\begin{array}{l}3.53^{* *} \\
{[2.06]}\end{array}$ & $\begin{array}{l}3.50^{* *} \\
{[2.00]}\end{array}$ & $\begin{array}{l}3.53^{* *} \\
{[1.99]}\end{array}$ \\
\hline Foreign Headq. Dummy & $\begin{array}{c}0.29 \\
{[0.34]}\end{array}$ & $\begin{array}{c}0.37 \\
{[0.44]}\end{array}$ & & $\begin{array}{c}3.66 \\
{[0.96]}\end{array}$ & $\begin{array}{c}3.49 \\
{[0.93]}\end{array}$ & $\begin{array}{c}-1.68 \\
{[-0.32]}\end{array}$ & $\begin{array}{c}-1.24 \\
{[-0.23]}\end{array}$ \\
\hline$\%$ Foreign Subsidiaries & $\begin{array}{c}-0.0062 \\
{[-0.62]}\end{array}$ & & & $\begin{array}{l}0.015 \\
{[0.80]}\end{array}$ & & & \\
\hline Foreign Subs. Dummy & & $\begin{array}{c}-0.67 \\
{[-0.96]}\end{array}$ & & & $\begin{array}{c}2.46 \\
{[1.60]}\end{array}$ & $\begin{array}{c}2.30 \\
{[1.35]}\end{array}$ & $\begin{array}{c}2.58 \\
{[1.52]}\end{array}$ \\
\hline $\ln$ (Plan Assets - Total) & & & & & & $\begin{array}{l}-1.14^{*} \\
{[-1.97]}\end{array}$ & \\
\hline $\ln$ (Plan Assets - Average) & & & & & & & $\begin{array}{c}-0.87 \\
{[-1.53]}\end{array}$ \\
\hline Constant & $\begin{array}{c}-17.5^{* * *} \\
{[-27.4]}\end{array}$ & $\begin{array}{c}-17.2^{* * *} \\
{[-23.1]}\end{array}$ & $\begin{array}{c}-17.7 * * * \\
{[-4.36]}\end{array}$ & $\begin{array}{c}-21.2^{* * *} \\
{[-4.59]}\end{array}$ & $\begin{array}{c}-21.8^{* * *} \\
{[-4.76]}\end{array}$ & $\begin{array}{c}-8.47 \\
{[-0.96]}\end{array}$ & $\begin{array}{c}-11.0 \\
{[-1.21]}\end{array}$ \\
\hline $\begin{array}{l}\text { Observations } \\
\text { R-squared }\end{array}$ & $\begin{array}{c}257 \\
0.110\end{array}$ & $\begin{array}{c}257 \\
0.112\end{array}$ & $\begin{array}{c}114 \\
0.057\end{array}$ & $\begin{array}{c}113 \\
0.103\end{array}$ & $\begin{array}{c}113 \\
0.120\end{array}$ & $\begin{array}{c}104 \\
0.162\end{array}$ & $\begin{array}{c}104 \\
0.148\end{array}$ \\
\hline
\end{tabular}


Table 8

Subsamples

\section{Panel A - Trend and Cohort Effects}

Panel A reports the results for individual level regressions of international diversification on the percent invested in a target dated fund, the international diversification benchmark, a quadratic time trend and birth year cohort for different subsamples. Panel B reports the results of these same regressions, controlling for wealth effects. Column (2) excludes observations with (a) tenure $0-3$, age $>35$, (b) tenure 4-5, age $>40$, (c) tenure 6-10, age $>45$, (d) tenure 11-15, age $>50$, (e) tenure 16-20, age $>55$, (f) those with missing tenure. Column (3) excludes observations with salaries $>=100,000$ and account balances $>=200,000$, along with those that have missing information for either variable. Column (4) is a combination of the exclusion rules specified in columns (2) and (3). Column (5) exclusions observations with bond allocations over 50\% and Column (6) uses international stocks as the dependent variable. All variables are defined in the Appendix. T-statistics are in brackets. The superscript $* * *$ denotes significance at the $1 \%$ level, $* *$ at the $5 \%$ level and * at the $10 \%$ level. Standard errors clustered at the firm level significant at the 5\% level are denoted by bold and underlined t-statistics, while significance at the $10 \%$ level is denoted by underlined t-statistics. The sample period is 2006 to 2011 .

\begin{tabular}{|c|c|c|c|c|c|c|}
\hline Variables & $\begin{array}{l}\text { (1) } \\
\text { Idiv }\end{array}$ & $\begin{array}{l}(2) \\
\text { idiv }\end{array}$ & $\begin{array}{l}\text { (3) } \\
\text { idiv }\end{array}$ & $\begin{array}{l}(4) \\
\text { idiv } \\
\end{array}$ & $\begin{array}{l}\text { (5) } \\
\text { idiv } \\
\end{array}$ & $\begin{array}{c}(6) \\
\text { Int'l Stock }\end{array}$ \\
\hline$\%$ target date fund & $\begin{array}{c}0.068^{* * *} \\
{[598]}\end{array}$ & $\begin{array}{c}0.039 * * * \\
{[199]}\end{array}$ & $\begin{array}{c}0.067^{* * *} \\
{[517]}\end{array}$ & $\begin{array}{c}0.037^{* * *} \\
{[169]}\end{array}$ & $\begin{array}{c}0.065^{* * *} \\
{[568]}\end{array}$ & $\begin{array}{c}0.077^{* * *} \\
{[850]}\end{array}$ \\
\hline Int'l diversif. benchmark & $\begin{array}{c}0.21^{* * *} \\
{[66.3]}\end{array}$ & $\begin{array}{c}0.18^{* * *} \\
{[30.5]}\end{array}$ & $\begin{array}{c}0.23 * * * \\
{[57.8]}\end{array}$ & $\begin{array}{c}0.12^{* * * *} \\
{[18.1]}\end{array}$ & $\begin{array}{c}0.21^{* * *} \\
{[62.5]}\end{array}$ & $\begin{array}{c}0.33^{* * *} \\
{[133]}\end{array}$ \\
\hline Trend & $\begin{array}{c}0.066^{* * *} \\
{[15.9]}\end{array}$ & $\begin{array}{c}0.20 * * * \\
{[21.3]}\end{array}$ & $\begin{array}{c}-0.073^{* * *} \\
{[-14.5]}\end{array}$ & $\begin{array}{c}-0.19 * * * \\
{[-16.3]}\end{array}$ & $\begin{array}{c}0.11^{* * *} \\
{[25.8]}\end{array}$ & $\begin{array}{c}-0.35^{* * *} \\
{[-113]}\end{array}$ \\
\hline Trend $^{2}$ & $\begin{array}{c}0.0056^{* * *} \\
{[40.4]}\end{array}$ & $\begin{array}{c}-0.00096^{* * *} \\
{[-3.15]}\end{array}$ & $\begin{array}{c}0.011^{* * *} \\
{[63.6]}\end{array}$ & $\begin{array}{c}0.013^{* * *} \\
{[33.3]}\end{array}$ & $\begin{array}{c}0.0041^{* * *} \\
{[28.5]}\end{array}$ & $\begin{array}{c}0.017^{* * *} \\
{[158]}\end{array}$ \\
\hline Cohort & $\begin{array}{c}0.17^{* * *} \\
{[510]}\end{array}$ & $\begin{array}{c}0.18^{* * *} \\
{[298]}\end{array}$ & $\begin{array}{c}0.16^{* * * *} \\
{[386]}\end{array}$ & $\begin{array}{c}0.19 * * * \\
{[250]}\end{array}$ & $\begin{array}{c}0.18^{* * * *} \\
{[523]}\end{array}$ & $\begin{array}{c}0.22^{* * *} \\
{[\mathbf{8 9 0 ]}}\end{array}$ \\
\hline Constant & $\begin{array}{c}-10.0 * * * \\
{[-51.3]}\end{array}$ & $\begin{array}{c}-7.10^{* * *} \\
{[-19.5]}\end{array}$ & $\begin{array}{c}-9.97^{* * *} \\
{[-41.3]}\end{array}$ & $\begin{array}{c}-2.38^{* * *} \\
{[-5.40]}\end{array}$ & $\begin{array}{c}-10.3^{* * *} \\
{[-51.3]}\end{array}$ & $\begin{array}{c}-22.9^{* * *} \\
{[-\mathbf{1 5 4 ]}}\end{array}$ \\
\hline $\begin{array}{l}\text { Observations } \\
\text { Adjusted R-squared }\end{array}$ & $\begin{array}{c}17,426,447 \\
0.054\end{array}$ & $\begin{array}{l}5,974,880 \\
0.033\end{array}$ & $\begin{array}{c}10,759,074 \\
0.059\end{array}$ & $\begin{array}{c}3,951,158 \\
0.036\end{array}$ & $\begin{array}{c}16,253,871 \\
0.056\end{array}$ & $\begin{array}{c}19,390,331 \\
0.097\end{array}$ \\
\hline Subsample & Whole Sample & $\begin{array}{l}\text { Age-Tenure } \\
\text { Screen }\end{array}$ & $\begin{array}{c}\text { Salary-Account } \\
\text { Screen }\end{array}$ & $\begin{array}{c}\text { Age/Tenure } \\
\text { and } \\
\text { Salary/Account }\end{array}$ & $\begin{array}{l}\text { Exclude High Bond } \\
\text { Allocations }\end{array}$ & $\begin{array}{c}\text { Int'l Stock as } \\
\text { dependent var. }\end{array}$ \\
\hline
\end{tabular}


Panel B - Income, Wealth and International Diversification

\begin{tabular}{|c|c|c|c|c|c|c|}
\hline Variables & $\begin{array}{l}\text { (1) } \\
\text { idiv } \\
\end{array}$ & $\begin{array}{l}\text { (2) } \\
\text { idiv } \\
\end{array}$ & $\begin{array}{l}\text { (3) } \\
\text { idiv } \\
\end{array}$ & $\begin{array}{l}\text { (4) } \\
\text { idiv } \\
\end{array}$ & $\begin{array}{l}(5) \\
\text { idiv } \\
\end{array}$ & $\begin{array}{c}(6) \\
\text { Int'l Stock } \\
\end{array}$ \\
\hline$\%$ target date fund & $\begin{array}{c}0.066^{* * *} \\
{[394]}\end{array}$ & $\begin{array}{c}0.038^{* * *} \\
{[138]}\end{array}$ & $\begin{array}{c}0.067^{* * *} \\
{[\mathbf{3 8 1}]}\end{array}$ & $\begin{array}{c}0.036^{* * *} \\
{[124]}\end{array}$ & $\begin{array}{c}0.062 * * * \\
{[369]}\end{array}$ & $\begin{array}{c}0.082^{* * *} \\
{[612]}\end{array}$ \\
\hline Int'l diversification benchmark & $\begin{array}{c}0.36^{* * *} \\
{[77.6]}\end{array}$ & $\begin{array}{c}0.27^{* * *} \\
{[34.4]}\end{array}$ & $\begin{array}{c}0.25^{* * *} \\
{[48.9]}\end{array}$ & $\begin{array}{c}0.15^{* * *} \\
{[17.4]}\end{array}$ & $\begin{array}{c}0.34^{* * *} \\
{[71.1]}\end{array}$ & $\begin{array}{c}0.44^{* * *} \\
{[122]}\end{array}$ \\
\hline Trend & $\begin{array}{c}-0.054^{* * *} \\
{[-9.35]}\end{array}$ & $\begin{array}{c}-0.18^{* * *} \\
{[-13.4]}\end{array}$ & $\begin{array}{c}-0.072 * * * \\
{[-11.3]}\end{array}$ & $\begin{array}{c}-0.20^{* * *} \\
{[-13.8]}\end{array}$ & $\begin{array}{c}0.0083 \\
{[1.38]}\end{array}$ & $\begin{array}{c}-0.48^{* * *} \\
{[-107]}\end{array}$ \\
\hline Trend $^{2}$ & $\begin{array}{c}0.0084^{* * *} \\
{[42.8]}\end{array}$ & $\begin{array}{c}0.0100^{* * *} \\
{[22.6]}\end{array}$ & $\begin{array}{c}0.011^{* * *} \\
{[50.0]}\end{array}$ & $\begin{array}{c}0.013^{* * *} \\
{[27.1]}\end{array}$ & $\begin{array}{c}0.0063^{* * *} \\
{[31.2]}\end{array}$ & $\begin{array}{c}0.020^{* * *} \\
{[133]}\end{array}$ \\
\hline Cohort & $\begin{array}{c}0.14^{* * *} \\
{[276]}\end{array}$ & $\begin{array}{c}0.17^{* * *} \\
{[168]}\end{array}$ & $\begin{array}{c}0.15^{* * *} \\
{[270]}\end{array}$ & $\begin{array}{c}0.18^{* * *} \\
{[164]}\end{array}$ & $\begin{array}{c}0.15^{* * *} \\
{[288]}\end{array}$ & $\begin{array}{c}0.23^{* * *} \\
{[568]}\end{array}$ \\
\hline ln(annual salary) & $\begin{array}{c}-2.73^{* * *} \\
{[-83.5]}\end{array}$ & $\begin{array}{c}-1.38^{* * *} \\
{[-19.8]}\end{array}$ & $\begin{array}{c}-2.17^{* * *} \\
{[-60.2]}\end{array}$ & $\begin{array}{l}-0.097 \\
{[-1.27]}\end{array}$ & $\begin{array}{c}-2.82^{* * *} \\
{[-84.9]}\end{array}$ & $\begin{array}{c}-2.34^{* * *} \\
{[-94.2]}\end{array}$ \\
\hline $\ln (\text { annual salary })^{2}$ & $\begin{array}{l}0.20^{* * *} \\
\lceil 112\rfloor\end{array}$ & $\begin{array}{l}0.13^{* * *} \\
{[34.5]}\end{array}$ & $\begin{array}{l}0.15^{* * *} \\
{[75.8]}\end{array}$ & $\begin{array}{c}0.040 * * * \\
{[9.39]}\end{array}$ & $\begin{array}{l}0.21^{* * *} \\
{[115]}\end{array}$ & $\begin{array}{l}0.18^{* * *} \\
{[133]}\end{array}$ \\
\hline $\ln ($ account value $)$ & $\begin{array}{c}0.80^{* * *} \\
{[50.9]}\end{array}$ & $\begin{array}{c}0.55^{* * *} \\
{[20.3]}\end{array}$ & $\begin{array}{l}1.17^{* * *} \\
{[63.4]}\end{array}$ & $\begin{array}{l}1.09 * * * \\
{[34.8]}\end{array}$ & $\begin{array}{c}0.96^{* * *} \\
{[60.1]}\end{array}$ & $\begin{array}{c}0.25^{* * *} \\
{[21.4]}\end{array}$ \\
\hline $\ln (\text { account value })^{2}$ & $\begin{array}{c}-0.051^{* * *} \\
{[-57.1]}\end{array}$ & $\begin{array}{c}-0.042^{* * *} \\
{[-27.9]}\end{array}$ & $\begin{array}{c}-0.074^{* * *} \\
{[-67.6]}\end{array}$ & $\begin{array}{c}-0.076^{* * *} \\
{[-41.0]}\end{array}$ & $\begin{array}{c}-0.061^{* * *} \\
{[-67.9]}\end{array}$ & $\begin{array}{c}-0.00063 \\
{[-0.95]}\end{array}$ \\
\hline $\ln ($ house value Zillow) & $\begin{array}{c}0.63^{* * *} \\
{[71.9]}\end{array}$ & $\begin{array}{c}0.50^{* * *} \\
{[32.3]}\end{array}$ & $\begin{array}{c}0.49^{* * *} \\
{[49.7]}\end{array}$ & $\begin{array}{c}0.47^{* * *} \\
{[27.6]}\end{array}$ & $\begin{array}{c}0.88^{* * *} \\
{[96.4]}\end{array}$ & $\begin{array}{c}0.30^{* * *} \\
{[43.7]}\end{array}$ \\
\hline Constant & $\begin{array}{c}-20.5^{* * *} \\
{[-58.8]}\end{array}$ & $\begin{array}{c}-16.8 * * * \\
{[-25.8]}\end{array}$ & $\begin{array}{c}-15.0 * * * \\
{[-39.5]}\end{array}$ & $\begin{array}{c}-15.4 * * * \\
{[-21.8]}\end{array}$ & $\begin{array}{l}-23.6 * * * \\
{[-66.1]}\end{array}$ & $\begin{array}{c}-31.3^{* * *} \\
{[-116]}\end{array}$ \\
\hline $\begin{array}{l}\text { Observations } \\
\text { Adjusted R-squared }\end{array}$ & $\begin{array}{c}8,553,859 \\
0.047\end{array}$ & $\begin{array}{c}3,112,021 \\
0.031\end{array}$ & $\begin{array}{c}6,777,252 \\
0.056\end{array}$ & $\begin{array}{c}2,514,651 \\
0.037\end{array}$ & $\begin{array}{c}7,949,148 \\
0.050\end{array}$ & $\begin{array}{c}9,371,372 \\
0.094\end{array}$ \\
\hline Subsample & Whole & $\begin{array}{c}\text { Age- } \\
\text { Tenure } \\
\text { Screen }\end{array}$ & $\begin{array}{l}\text { Salary- } \\
\text { Account } \\
\text { Screen }\end{array}$ & $\begin{array}{c}\text { Age/Tenure and } \\
\text { Salary/Account } \\
\text { Screen }\end{array}$ & $\begin{array}{l}\text { ex-High Bond } \\
\text { Allocations }\end{array}$ & $\begin{array}{c}\text { Int'l Stock as } \\
\text { dependent } \\
\text { variable }\end{array}$ \\
\hline
\end{tabular}




\section{Appendix 1: Firm Characteristics}

Panel A presents the mean, median, standard deviation and $5^{\text {th }}$ and $95^{\text {th }}$ percentiles for firms in our sample between 2006 and 2011. The $5^{\text {th }}$ percentile is an average of the $4^{\text {th }}, 5^{\text {th }}$ and $6^{\text {th }}$ percentiles, the median is the average of the $49^{\text {th }}, 50^{\text {th }}$, and $51^{\text {st }}$ percentiles and the $95^{\text {th }}$ percentile is the average of the $94^{\text {th }}, 95^{\text {th }}$, and $96^{\text {th }}$ percentile. Panels B and C present these same statistics for all firms in Compustat and the S\&P 500 between 2006 and 2011, respectively. Note that firm age in these two cases is calculated as number of years in Compustat.

\section{Panel A - Sample Firms}

\begin{tabular}{lccccc}
\hline Variables & mean & median & sd & p5 & p95 \\
\hline Assets (USD mn) & 46,286 & 4,378 & 254,441 & 152 & 88,847 \\
Debt (USD mn) & 26,376 & 1,616 & 227,237 & 32 & 16,042 \\
Net Income (USD mn) & 167 & 132 & 4,481 & -642 & 2,935 \\
Sales (USD mn) & 9,337 & 3,122 & 17,619 & 133 & 43,044 \\
Capex (USD mn) & 694 & 161 & 1,156 & 3 & 3,596 \\
Leverage (\%) & 31 & 29 & 21 & 5 & 66 \\
Sales/Assets (\%) & 95 & 77 & 87 & 11 & 234 \\
Profitability (\%) & 1.9 & 2.9 & 11.2 & -14.4 & 13.0 \\
Investment Intensity (\%) & 4.5 & 3.5 & 3.8 & 0.1 & 12.3 \\
ROA & 2.1 & 3.0 & 9.3 & -13.9 & 13.1 \\
ROE & -111.3 & 5.8 & 1405.9 & -52.2 & 13.8 \\
Annual Return (\%) & 14.9 & 5.6 & 104.9 & -61.6 & 79.6 \\
Number of Employees & 17,095 & 4,483 & 42,969 & 232 & 66,633 \\
Firm Age (years) & 69 & 65 & 45 & 9 & 148 \\
Plan Assets - & & & & & 4,342 \\
Total per firm (USD mn) & 925 & 297 & 2,055 & 22 & 3,164 \\
Plan Assets - Average per & & & & & 24 \\
plan within firm (USD mn) & 688 & 247 & 1,271 & & \\
\hline
\end{tabular}




\section{Panel B - Compustat Firms}

\begin{tabular}{lccccc}
\hline Variables & mean & median & $\mathrm{sd}$ & $\mathrm{p} 5$ & $\mathrm{p} 95$ \\
\hline Assets (USD mn) & 4,578 & 558 & 16,748 & 8 & 20,959 \\
Debt (USD mn) & 1,174 & 99 & 4,100 & 0 & 5,595 \\
Net Income (USD mn) & 150 & 6 & 595 & -96 & 912 \\
Sales (USD mn) & 2,275 & 254 & 6,508 & 3 & 11,622 \\
Capex (USD mn) & 171 & 11 & 549 & 0 & 890 \\
Leverage (\%) & 32 & 22 & 62 & 1 & 81 \\
Sales/Assets (\%) & 86 & 66 & 82 & 5 & 248 \\
Profitability (\%) & -12.6 & 1.4 & 91.0 & -70.5 & 15.3 \\
Investment Intensity (\%) & 5.3 & 2.8 & 7.5 & 0.1 & 20.6 \\
ROA & -9.4 & 1.6 & 68.3 & -62.2 & 16.4 \\
ROE & -8.4 & 3.9 & 45.4 & -71.1 & 15.9 \\
Annual Return (\%) & 5.6 & 0.0 & 51.5 & -68.3 & 94.2 \\
Number of Employees & 7,576 & 951 & 20,404 & 24 & 38,945 \\
Firm Age (years in Compustat) & 14 & 9 & 14 & 0 & 47 \\
\hline
\end{tabular}

\section{Panel C - S\&P 500 Firms}

\begin{tabular}{lccccc}
\hline Variables & mean & median & sd & p5 & p95 \\
\hline Assets (USD mn) & 53,556 & 12,524 & 186,742 & 2,145 & 176,675 \\
Debt (USD mn) & 16,236 & 2,921 & 74,226 & 6 & 34,558 \\
Net Income (USD mn) & 1,281 & 573 & 3,976 & -617 & 5,768 \\
Sales (USD mn) & 18,365 & 7,819 & 35,079 & 1,336 & 71,725 \\
Capex (USD mn) & 1,034 & 285 & 2,396 & 4 & 3,946 \\
Leverage (\%) & 25 & 23 & 18 & 0 & 56 \\
Sales/Assets (\%) & 84 & 67 & 73 & 7 & 234 \\
Profitability (\%) & 5.8 & 5.5 & 8.1 & -3.5 & 17.2 \\
Investment Intensity (\%) & 4.3 & 3.1 & 4.6 & 0.0 & 12.2 \\
ROA & 5.8 & 5.5 & 8.1 & -4.3 & 18.0 \\
ROE & 3.4 & 6.0 & 16.3 & -11.9 & 12.1 \\
Annual Return (\%) & 8.3 & 7.5 & 41.5 & -54.5 & 71.1 \\
Number of Employees & 48,038 & 19,283 & 113,816 & 2,115 & 194,120 \\
Firm Age (years in Compustat) & 35 & 35 & 19 & 8 & 60 \\
\hline
\end{tabular}




\section{Panel D Sample Firms - Private versus Public}

Panel D presents the mean, median, standard deviation, $5^{\text {th }}$ and $95^{\text {th }}$ percentiles and number of firm-year observations in our sample between 2006 and 2011. The $5^{\text {th }}$ percentile is an average of the $4^{\text {th }}, 5^{\text {th }}$ and $6^{\text {th }}$ percentiles, the median is the average of the $49^{\text {th }}, 50^{\text {th }}$, and $51^{\text {st }}$ percentiles and the $95^{\text {th }}$ percentile is the average of the $94^{\text {th }}, 95^{\text {th }}$, and $96^{\text {th }}$ percentile. Summary statistics are decomposed into private firms and public firms. There are 178 private firms, 108 public firms and 4 firms who switch from public to private or private to public in the sample.

\section{Public Firms}

\begin{tabular}{lcccccc}
\hline Variable & \# Obs & mean & median & sd & p5 & p95 \\
\hline Assets (USD mn) & 403 & 50,464 & 5,895 & 282,944 & 439 & 70,368 \\
Debt (USD mn) & 403 & 28,513 & 1,627 & 237,620 & 31 & 16,509 \\
Net Income (USD mn) & 403 & 255 & 200 & 5,010 & -515 & 3,112 \\
Sales (USD mn) & 403 & 10,923 & 3,730 & 19,154 & 551 & 50,853 \\
Capex (USD mn) & 403 & 700 & 166 & 1,178 & 3 & 3,651 \\
Leverage (\%) & 403 & 30 & 28 & 21 & 4 & 59 \\
Sales/Assets (\%) & 403 & 82 & 72 & 52 & 14 & 183 \\
Profitability (\%) & 403 & 1.9 & 3.2 & 11.0 & -15.1 & 12.7 \\
Investment Intensity (\%) & 403 & 4.4 & 3.4 & 3.8 & 0.1 & 11.7 \\
ROA & 401 & 2.4 & 3.3 & 9.4 & -14.7 & 13.4 \\
ROE & 399 & -111.3 & 5.8 & 1405.9 & -52.2 & 13.8 \\
Annual Return (\%) & 397 & 15.8 & 6.8 & 105.8 & -61.6 & 82.8 \\
Number of Employees & 406 & 30,394 & 10,204 & 61,706 & 1,400 & 142,833 \\
Firm Age (years) & 388 & 76 & 74 & 47 & 9 & 152 \\
Plan Assets - & & & & & & 5,207 \\
Total per firm (USD mn) & 271 & 1,284 & 457 & 2,760 & 44 & 4,437 \\
Plan Assets - Average per & & & & & & \\
plan within firm (USD mn) & 270 & 911 & 395 & 1,549 & 46 & \\
\hline
\end{tabular}

\section{Private Firms}

\begin{tabular}{|c|c|c|c|c|c|c|}
\hline Variable & $\#$ Obs & mean & median & $\mathrm{sd}$ & p5 & p95 \\
\hline Assets (USD mn) & 111 & 31,117 & 1,176 & 95,164 & 15 & 263,255 \\
\hline Debt (USD mn) & 38 & 3,712 & 1,448 & 4,312 & 282 & 13,668 \\
\hline Net Income (USD mn) & 109 & -159 & 10 & 1,208 & $-1,990$ & 735 \\
\hline Sales (USD mn) & 98 & 2,814 & 1,225 & 5,131 & 13 & 18,048 \\
\hline Capex (USD mn) & 37 & 622 & 68 & 889 & 9 & 2,416 \\
\hline Leverage $(\%)$ & 38 & 45 & 45 & 22 & 6 & 84 \\
\hline Sales/Assets (\%) & 96 & 152 & 106 & 156 & 5 & 384 \\
\hline Profitability $(\%)$ & 107 & 2.0 & 1.4 & 11.8 & -12.1 & 13.7 \\
\hline Investment Intensity (\%) & 35 & 5.2 & 4.1 & 3.9 & 0.2 & 12.9 \\
\hline ROA & 66 & 0.3 & 1.1 & 8.0 & -10.9 & 7.7 \\
\hline ROE & 0 & & & & & \\
\hline Annual Return (\%) & 9 & -22.2 & 0.0 & 33.3 & -95.5 & 0.8 \\
\hline Number of Employees & 549 & 7,260 & 2,433 & 13,122 & 151 & 31,826 \\
\hline $\begin{array}{l}\text { Firm Age (years) } \\
\text { Plan Assets - }\end{array}$ & 574 & 63 & 62 & 42 & 7 & 142 \\
\hline Total per firm (USD mn) & 370 & 672 & 217 & 1,277 & 19 & 3,663 \\
\hline $\begin{array}{l}\text { Plan Assets - Average per } \\
\text { plan within firm (USD mn) }\end{array}$ & 368 & 528 & 177 & 994 & 19 & 2,641 \\
\hline
\end{tabular}




\section{Appendix 2: Employee Characteristics}

\section{Panel A Employee Characteristics across Firms}

Panel A presents the mean, median, standard deviation and $5^{\text {th }}$ and $95^{\text {th }}$ percentiles for all individuals in the sample between 2006 and 2011 (the data include both stock market participants and non-stock market participants).

\begin{tabular}{lccccc}
\hline Variables & mean & median & $\mathrm{sd}$ & $\mathrm{p} 5$ & $\mathrm{p} 95$ \\
\hline Salary & 64,166 & 52,561 & 52,763 & 16,925 & 140,964 \\
Total Account Value & 70,581 & 25,786 & 125,899 & 389 & 285,507 \\
Contribution Rate & $6.0 \%$ & $5.0 \%$ & $6.1 \%$ & $0.0 \%$ & $17.0 \%$ \\
Tenure & 12.3 & 9.9 & 9.9 & 0.9 & 31.7 \\
Age & 45 & 46 & 12 & 27 & 64 \\
Cohort & 1959 & 1960 & 12 & 1940 & 1980 \\
\hline
\end{tabular}

\section{Panel B Current Population Survey (CPS)}

Panel B presents the mean, median, standard deviation and $5^{\text {th }}$ and $95^{\text {th }}$ percentiles for individual statistics in the Current Population Survey between 2006 and 2011. In order to extract tenure data, we use the January CPS Displaced Worker, Employee Tenure and Occupational Mobility Supplement for years 2006, 2008, and 2010, while 2007, 2009, and 2011 data come from the January CPS. The summary statistics reported in this table are the average of the annual statistics.

\begin{tabular}{lccccc}
\hline Variables & mean & median & sd & $\mathrm{p} 5$ & $\mathrm{p} 95$ \\
\hline Salary & 45,437 & 37,175 & 30,045 & 14,685 & 109,840 \\
Tenure & 7.7 & 5.0 & 8.2 & 0.3 & 25.7 \\
Age & 41 & 42 & 12 & 23 & 62 \\
\hline
\end{tabular}




\section{Appendix 3: Variable Description}

\begin{abstract}
Individual Level Variables Description
International Diversification Allocation to international equities over allocation to all (idiv)

Cohort

Age

Total Account Value (log)

House Value - Zillow (log) equities. The total equity allocation is defined as the combination of investments in Large Cap Stocks, Small and Mid Cap Stocks, Individual Stocks, Company Stock and International Stocks. This series is individual specific. Source: Financial Engines

The cohort variable is defined as the individual's birth year minus 1900. The cohort is set to 1993 if the individual is born after 1990 and to 1940 if the individual is born before 1945. This data is individual specific. Source: Financial Engines

Age is defined as the difference between the observation date and the individual's birth date. Source: Financial Engines

Total account values represent the dollar amount an individual has contributed to the 401(k) account in Financial Engines. This value is first deflated to 2005 prices using the Consumer Price Index for All Urban Consumers and then the natural logarithm is taken. Source: Financial Engines and U.S. Department of Labor: Bureau of Labor Statistics

The natural logarithm of house values deflated to 2005 prices using the Consumer Price Index for All Urban Consumers. We match the Zillow average house value in a zip code to each individual based on the zip code they live in according to Financial Engines. Source: Zillow, U.S. Department of Labor: Bureau of Labor Statistics, Financial Engines
\end{abstract}

House Value - Census (log)

Annual Salary (log)
The natural logarithm of median house values in dollars at the zip code level. This variable is matched to the individual data using the zip code where the user lives. Source: U.S. Census Bureau, 2008-2012 American Community Survey - Table B25077: Median Housing Value of Owner-Occupied Housing Units (Dollars)

Annual Salary represents the dollar amount an individual is paid by the company. The dollar amount is first deflated to 2005 prices using the Consumer Price Index for All Urban Consumers and then the natural logarithm is taken. Source: Financial Engines and U.S. Department of Labor: Bureau of Labor Statistics 
$\%$ in target dated fund

International Diversification Benchmark

Relative Returns

MN Experienced Returns

Returns Chasing

Flight to Safety
Amount allocated to target dated funds as a percentage of the individual's total account value. This data is individual specific. Source: Financial Engines.

The ratio of international market cap (MSCI Market Cap All Countries ex-US) to the sum of international and domestic market cap (MSCI Market Cap All Countries). We obtain daily data from MSCI and match the ratio of market caps to the date on which the individual's data point is drawn. Source: MSCI and Financial Engines.

International stock returns (MSCI All Countries ex-US returns) in excess of US stock returns (MSCI US) between the period t-1 and t. For each individual, we calculate the cumulative international stock return between $\mathrm{t}-1$ and $\mathrm{t}$, the cumulative return for US stocks between $\mathrm{t}-1$, and $\mathrm{t}$ and take the difference. Note that $t$ is defined as the day on which the individual is observed, while $\mathrm{t}-1$ is the previous observation. Source: MSCI and Financial Engines.

Following the methodology proposed by Malmendier and Nagel (2011), the experienced returns measure is the weighted average of past returns with weights that depend on an individual's age at time t, how many years ago the return was realized and a parameter that controls for the shape of the weighting function. This paper builds experienced returns based on international stock returns in excess of US stock returns.

This variable is constructed using the same methodology as MN Experienced Returns, but uses international stock returns as the relevant past returns.

We borrow the flight to safety (FTS) dummy variable for the United States from Baele, Bekaert, Inghelbrecht and Wei (2013). They use data on bond and stock returns to measure the occurrence of stress periods in which stock markets decline and liquid benchmark bonds increase in value.

\section{Zip Code Variables}

Bachelor's Degree or Higher

\section{Description}

Bachelor's degree or higher as a percentage of population over 25 years old. Bachelor's degree or higher is the sum of people with a bachelor's degree (hd01_vd22), master's degree (hd01_vd23), professional school degree (hd01_vd24) and doctorate degree (hd01_vd25). This is divided by the total population 25 years and over in the area (hd01_vd01). Census labels are in parentheses. Data is at a zip code level. Source: U.S. Census Bureau, 2008- 
Advanced Degree

Less than college degree

Bachelor's Degree

Foreign Born Population

Foreign Born Population Latin America
2012 American Community Survey - Table B15003: Educational attainment for the population over 25 years and over

Master's degree or higher as a percentage of population over 25 years old. Master's degree or higher is the sum of people with a master's degree (hd01_vd23), professional school degree (hd01_vd24) and doctorate degree (hd01_vd25). This is divided by the total population 25 years and over in the area (hd01_vd01). Census labels are in parentheses. Data is at a zip code level. Source: U.S. Census Bureau, 2008-2012 American Community Survey - Table B15003 - Educational attainment for the population over 25 years and over

Less than college degree as a percentage of population over 25 years old. Less than college degree is the sum of people with a regular high school diploma (hd01_vd17), GED high school diploma (hd01_vd18), some college less than 1 year (hd01_vd19), some college - more than 1 year (hd01_vd20) and associate's degree (hd01_vd21). This sum is divided by the total population 25 years and over in the area (hd01_vd01). Census labels are in parentheses. Data is at a zip code level. Source: U.S. Census Bureau, 2008-2012 American Community Survey

- Table B15003: Educational attainment for the population over 25 years and over

Bachelor's degree as a percentage of population over 25 years old. This variable is defined as people with a bachelor's degree (hd01_vd22) divided by the total population 25 years and over in the area (hd01_vd01). Census labels are in parentheses. Data is at a zip code level. Source: U.S. Census Bureau, 2008-2012 American Community Survey - Table B15003: Educational attainment for the population over 25 years and over

Foreign born population over total population. This variable is defined as Total Foreign Born Population (hd01_vd01) over total population in the area (hc01_vc03). Census labels are in parentheses. Data is at a zip code level. Source: U.S. Census Bureau, 2007-2011 American Community Survey - Tables B05007: Place of birth by year of entry by citizenship status for the foreignborn population and DP05: ACS demographic and housing estimates

Foreign born population from Latin America over total population. This variable is defined as the Latin American born population (hd01_vd28) over total population in the 
Foreign Born Population Europe

Foreign Born Population Asia

Foreign Born Population Other

State Exports/GDP

State Openness

GDP per capita area (hc01_vc03). Census labels are in parentheses. Data is at a zip code level. Source: U.S. Census Bureau, 20072011 American Community Survey - Tables B05007: Place of birth by year of entry by citizenship status for the foreign-born population and DP05: ACS demographic and housing estimates

Foreign born population from Europe over total population. This variable is defined as the European born population (hd01_vd02) over total population in the area (hc01_vc03). Census labels are in parentheses. Data is at a zip code level. Source: U.S. Census Bureau, 2007-2011 American Community Survey - Tables B05007: Place of birth by year of entry by citizenship status for the foreignborn population and DP05: ACS demographic and housing estimates

Foreign born population from Asia over total population. This variable is defined as the Asian born population (hd01_vd15) over total population in the area (hc01_vc03). Census labels are in parentheses. Data is at a zip code level. Source: U.S. Census Bureau, 2007-2011 American Community Survey - Tables B05007: Place of birth by year of entry by citizenship status for the foreignborn population and DP05: ACS demographic and housing estimates

Foreign born population from a region other than Asia, Europe and Latin America over total population. This variable is defined as the "Other" born population (hd01_vd82) over total population in the area (hc01_vc03). Census labels are in parentheses. Data is at a zip code level. Source: U.S. Census Bureau, 2007-2011 American Community Survey - Tables B05007: Place of birth by year of entry by citizenship status for the foreignborn population and DP05: ACS demographic and housing estimates

Export of goods measured as a share of gross domestic product at the state level (ratio is average of 2008-2011 annual data). Source: U.S. Census Bureau and Bureau of Economic Analysis

The sum of exports and imports of goods measured as a share of gross domestic product at the state level (ratio is average of 2008-2011 annual data). Source: U.S. Census Bureau and Bureau of Economic Analysis

Per capita real GDP by state (chained 2005 dollars), 2005 to 2011 average. Data is annual. Source: Bureau of Economic Analysis 
GDP growth

Rural

Urban

Large Rural

Small Rural

Isolated

Long distance minutes

Distance to International Cities
Real GDP by state (millions of chained 2005 dollars). We take the 2000 to 2005 and 2006 to 2011 growth rates. Data is annual. Source: Bureau of Economic Analysis

Rural is a categorical variable which takes values 1 to 4 in integer units, with 1 representing the most urban areas and 4 the most isolated. The variable is constructed from the RUCA 2.0 variable in the Zip RUCA Code dataset. More specifically, a zip code is classified in the following way: (i) urban if RUCA2.0 is 1.0, 1.1, 2.0, 2.1, 3.0, 4.1, 5.1, 7.1, 8.1 , or 10.1 , (ii) large rural city/town if RUCA2.0 is 4.0, $4.2,5.0,5.2,6.0$, or 6.), (iii) small rural town if RUCA2.0 is 7.0, 7.2, 7.3, 7.4, 8.0, 8.2, 8.3, 8.4, 9.0, 9.1, 9.2, and isolated if RUCA2.0 is 10.0, 10.2, 10.3, 10.4, 10.5, or 10.6. Source: RUCA Rural Health Research Center

The variable Urban is a dummy variable equal to 1 if RUCA2.0 is equal to $1.0,1.1,2.0,2.1,3.0,4.1,5.1,7.1$, 8.1, or 10.1 (these are the metropolitan areas in the Zip RUCA Code dataset). Data is at the zip code level. Source: RUCA Rural Health Research Center

The variable Large Rural is a dummy variable equal to 1 if RUCA2.0 is equal to 4.0, 4.2, 5.0, 5.2, 6.0, or 6.1 (these are the large rural city/town areas in the Zip RUCA Code dataset). Data is at the zip code level. Source: RUCA Rural Health Research Center

The variable Small Rural is a dummy variable equal to 1 if RUCA2.0 is equal to 7.0, 7.2, 7.3, 7.4, 8.0, 8.2, 8.3, 8.4, 9.0, 9.1, 9.2 (these are the small rural town areas in the Zip RUCA Code dataset). Data is at the zip code level. Source: RUCA Rural Health Research Center

The variable Isolated is a dummy variable equal to 1 if RUCA2.0 is equal to $10.0,10.2,10.3,10.4,10.5$, or 10.6 (these are the isolated small rural areas in the Zip RUCA Code dataset). Data is at the zip code level. Source: RUCA Rural Health Research Center

Number of long distance hours from land lines and mobile phones scaled by total population. Data is at the state level and is the average of the annual data between 2000-2011. Source: FCC

Distance to international cities is the cumulative distance from each zip code to London, Tokyo, Toronto and Mexico City. To calculate the distance from a zip code to each city, we apply the haversine formula using the latitude and longitude of each point. This formula calculates the great-circle distance between two points (the shortest distance over the earth's surface), giving an 'as- 
Financial Literacy

House Value - Zillow (log)

House Value - Census (log) the-crow-flies' distance between the zip code and the city. We then add the four distances to produce the zip code's distance to international cities.

Source: federalgovernmentzipcodes.us

Mean number of correct quiz answers in financial knowledge survey. Multiple choice quiz questions include calculations involving interest rates and inflation, the relationship between bond prices and interest rates, risk and diversification, and the impact of short-term rates on life of a mortgage. Data is at the state level. Source: 2012 National Financial Capability Study Data Tables

The natural logarithm of house values at the zip code level deflated to 2005 prices using the Consumer Price Index for All Urban Consumers. We take the average of the deflated monthly data for the period that the zip code is in the sample (ranges between 2006-2011). Source: Zillow and U.S. Department of Labor: Bureau of Labor Statistics

The natural logarithm of median house values in dollars at the zip code level. Source: U.S. Census Bureau, 20082012 American Community Survey - Table B25077: Median Housing Value of Owner-Occupied Housing Units (Dollars)

\section{Firm Variables}

Private

Foreign Headquarter Dummy

Foreign Subsidiary Dummy

$\%$ Foreign Subsidiaries

Industry Openness

Firm Age (log)

\section{Description}

Dummy variable that takes the value of 1 if the firm is private and 0 if the firm is public. Source: Capital IQ

Dummy variable that takes the value of 1 if firm's ultimate parent is based in a country outside of the United States. Source: Capital IQ

Dummy variable equal to 1 if firm has a subsidiary in a country outside of the United States. Source: Orbis

Number of foreign subsidiaries over the total number of subsidiaries in the firm. If company has no subsidiaries, this variable takes the value of zero. Source: Orbis

The sum of exports and imports of goods measured as a share of gross output by industry (ratio is average of 20002011 annual data). Industry is classified at the 3-digit NAICS level. Source: U.S. Census Bureau and Bureau of Economic Analysis

Firm age is calculated as the difference between the current fiscal year and the year the firm was founded. Source: Capital IQ 
Number of Employees (log) Number of employees in the firm. Use data from Capital IQ only when Compustat data is missing. Given that Compustat reports number of employees in thousands, we multiply the data item "emp" by 1000 in order to be consistent with Capital IQ. We take the average of the annual data for the period that the firm is in the sample (ranges between 2005 and 2011). Source: Compustat and Capital IQ

Assets $(\log )$

Leverage

Sales/Assets

Profitability

Investment Intensity

Plan Assets - Total per firm Total assets (EOY) from the Form 5500. For firms with

Firm assets in USD million, data item "at" in Compustat, deflated to 2005 prices using the Consumer Price Index for All Urban Consumers. Use data from Capital IQ only when Compustat data is missing. We take the average of the annual data for the period that the firm is in the sample (ranges between 2005 and 2011). Source: Compustat, Capital IQ and U.S. Department of Labor: Bureau of Labor Statistics

Firm total debt over assets, data items $(\mathrm{dlc}+\mathrm{dltt}) / \mathrm{at}$ in Compustat. Use data from Capital IQ only when Compustat data is missing. We take the average of the annual data for the period that the firm is in the sample (ranges between 2005 and 2011). Source: Compustat and Capital IQ

Firm sales over assets, data items "sales" and "at" in Compustat. Use data from Capital IQ only when Compustat data is missing. We take the average of the annual data for the period that the firm is in the sample (ranges between 2005 and 2011). Source: Compustat and Capital IQ

Firm net income over assets, data items "ni" and "at" in Compustat. Use data from Capital IQ only when Compustat data is missing. We take the average of the annual data for the period that the firm is in the sample (ranges between 2005 and 2011). Source: Compustat and Capital IQ

Firm capex over assets, data items "capx" and "at" in Compustat. Use data from Capital IQ only when Compustat data is missing. We take the average of the annual data for the period that the firm is in the sample (ranges between 2005 and 2011). Source: Compustat and Capital IQ take the average over time. Data is in USD million. Source: Form 5500, US Department of Labor 
Plan Assets - Average per plan within firm
Total assets (EOY) from the Form 5500. For firms with more than one plan, we average total assets across all plans and then take the average over time. Data is in USD million. Source: Form 5500, US Department of Labor 


\section{RECENT WORKING PAPERS FROM THE CENTER FOR RETIREMENT RESEARCH AT BOSTON COLLEGE}

The Causes and Consequences of Financial Fraud Among Older Americans Keith Jacks Gamble, Patricia Boyle, Lei Yu, and David Bennett, November 2014

New Evidence on the Risk of Requiring Long-Term Care Leora Friedberg, Wenliang Hou, Wei Sun, Anthony Webb, and Zhenyu Li, November 2014

SSI at 62: Protecting the Vulnerable When Increasing Social Security's Early Entitlement Age Norma B. Coe and April Yanyuan Wu, June 2014

Why Do SSI and SNAP Enrollments Rise in Good Economic Times and Bad? Matthew S. Rutledge and April Yanyuan Wu, June 2014

The Impact of Mandatory Coverage on State and Local Budgets

Alicia H. Munnell, Jean-Pierre Aubry, and Anek Belbase, May 2014

Interest Rates and Economic Growth: Are They Related?

Barry P. Bosworth, May 2014

The Tradeoff Between Health and Wealth in Retirement Decisions Kristine M. Brown, May 2014

The Effect of Increasing Earnings Dispersion on Social Security Payroll Tax Receipts Richard Kopcke, Zhenyu Li, and Anthony Webb, May 2014

What Impact Does Social Security Have on the Use of Public Assistance Programs Among the Elderly?

Norma B. Coe and April Yanyuan Wu, May 2014

Differential Mortality and Retirement Benefits in the Health and Retirement Study Barry P. Bosworth and Kathleen Burke, April 2014

Adding Employer Contributions to Health Insurance To Social Security's Earnings and Tax Base

Karen E. Smith and Eric Toder, April 2014

Lower-Income Individuals Without Pensions: Who Misses Out and Why?

April Yanyuan Wu and Matthew S. Rutledge, March 2014

All working papers are available on the Center for Retirement Research website (http://crr.bc.edu) and can be requested by e-mail (crr@bc.edu) or phone (617-552-1762). 